Universidade de São Paulo

Faculdade de Saúde Pública

\title{
Envelhecimento e Funcionalidade: Uma Análise de Trajetórias
}

\section{Etienne Duim}

Tese apresentada ao Programa de PósGraduação em Epidemiologia, nível doutorado, para obtenção do título de Doutora em Ciências.

Orientador: Prof. Dr. José Leopoldo Ferreira Antunes.

FAPESP - Processo No: 2016/19696-3

FAPESP - Processo No: 2018/02401-6 


\section{Envelhecimento e Funcionalidade: Uma Análise de Trajetórias}

Etienne Duim

Tese apresentada ao Programa de Pósgraduação em Epidemiologia da Faculdade de Saúde Pública da Universidade de São Paulo para obtenção do título de doutor em Ciências.

Área de concentração: Epidemiologia

Orientador: Prof. Dr. José Leopoldo Ferreira Antunes

Versão Original

SÃO PAULO 
Autorizo a reprodução e divulgação total ou parcial deste trabalho, por qualquer meio convencional ou eletrônico, para fins de estudo e pesquisa, desde que citada a fonte.

As opiniões, hipóteses e conclusões ou recomendações expressas neste material são de responsabilidade da autora e não necessariamente refletem a visão da FAPESP ou da CAPES.

Catalogação da Publicação Ficha elaborada pelo Sistema de Geração Automática a partir de dados fornecidos pelo(a) autor(a) Bibliotecária da FSP/USP: Maria do Carmo Alvarez - CRB-8/4359

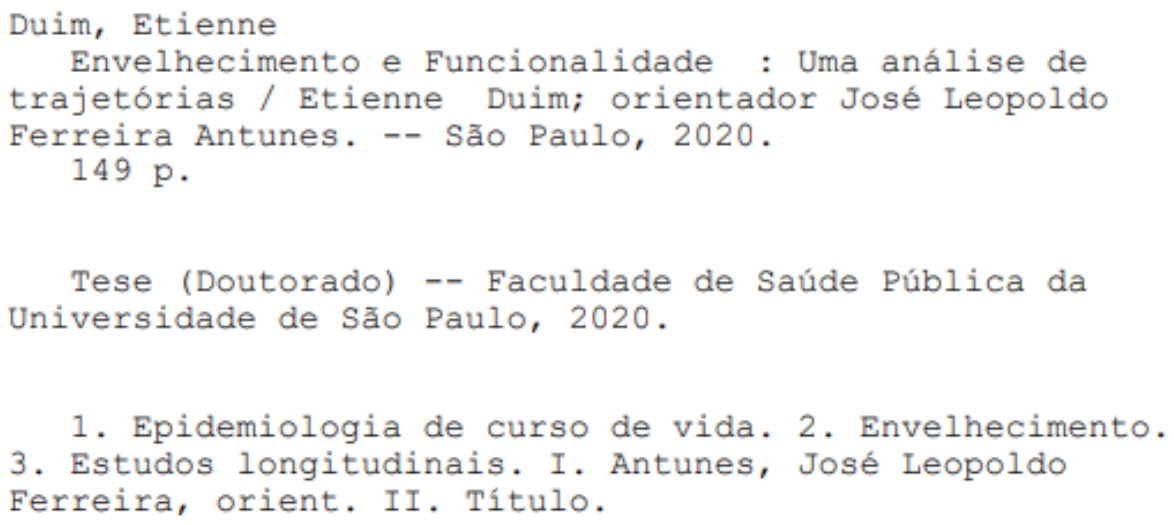




\section{DEDICATÓRIA}

Aos olhinhos que me viram nascere me guiaram pelo caminho do amor...

À minha querida Mãe-Vó Hélia. 


\section{AGRADECIMENTOS}

Gratidão, substantivo feminino que tem sua origem no latim, gratia, que significa graças, de modo mais abrangente pode ser considerado como sentimento de reconhecimento. Graças a pessoas muito especiais hoje eu estou aqui. Como não ser agradecida?

Tenho muita gratidão pela minha mãe, que construiu sozinha nosso alicerce, que criou dois filhos com todo amor do mundo. Que acertou, que errou, mas que em todas as tentativas buscou ser uma pessoa melhor e mostrar-nos como sê-lo também. Mãe Cristina, te ensinei a ser mãe e como sou grata a esse universo por ter a senhora no meu caminho. Eu te amo de um tamanho. Obrigada por sempre estar comigo.

Meus avós foram também peça fundamental neste tabuleiro. Sempre fui muito amada, muito amada! De uma maneira tão intensa que não consigo explicar, mas que foi e é uma dádiva sentir.

Ao Professor Leopoldo, meu orientador. O senhor merecia um capítulo inteiro. Uma simples frase de agradecimento não é suficiente expressar para o quão feliz me sinto por ter a oportunidade de trabalhar e aprender contigo. Você me aceitou de braços abertos, me guiou e conduziu por bons e nem tão bons momentos. Em um mundo repleto de ego, você sempre me deu voz, sempre acreditou nas minhas ideias malucas, acalmou minhas aflições, foi empático em momentos mil. Trouxe sensatez, me colocou no chão quando eu voava muito e se hoje estou aqui não foi apenas pelo meu esforço, mas foi também porque esteve sempre comigo. Grata sou por ter escolhido me orientar. Por ter me colocado na tua trajetória assim como te trago na minha!

Meus passos também foram guiados por uma baiana arretada. Uma mulher forte, porreta demais, que me mostrou com tanta paciência e amor os caminhos estatísticos... Minha trajetória nunca seria completa sem você, minha querida Valéria Lima Passos! Obrigada por compartilhar momentos, por guardar meus segredos, por gostar de mim assim como sou, uma pirulita louquinha que só vendo. No meu estágio na Holanda você foi professora, amiga, mãe, colo e amor. Obrigada por me receber de braços abertos em tua vida. Amo você grande!!

Aos professores que me acolheram aqui em São Paulo, todo meu carinho! Professora Maria Regina Cardoso e Professora Cassia Maria Buchalla, vocês me receberam e aceitaram por perto com muito carinho. Aprendi e aprendo muito com vocês, ensinamentos que levo comigo para vida.

Professor Jair Lício, que honra poder dizer que te tive presente guiando meus passos no mestrado e agora no doutorado. Obrigada pela gentileza de compartilhar o 
muito que sabe comigo! Como sou privilegiada! Tens meu carinho e gratidão por onde for.

Especial agradecimento à Dra Tereza Rosa e à Dra Manuela Roediger. Muito obrigada por aceitarem estar nesta etapa final! Também deixo meu agradecimento à Dra Fabiola Bof de Andrade e aos Professores Gizelton Pereira Alencar e Professor Alexandre Chiavegatto pelas instruções no início do meu processo.

Gratidão saudosa à Professora Maria Lucia Lebrão, uma mulher forte que acreditou no meu potencial mais que eu mesma, me incentivou e se hoje estou aqui devo muito a ela.

Agradeço à coordenadora do Estudo SABE, Dra Yeda Aparecida de Oliveira Duarte, por me permitir utilizar a base de dados do estudo durante o doutorado.

À Fundação de Amparo à Pesquisa do Estado de São Paulo (FAPESP), pelo financiamento do meu projeto de pesquisa e estágio no exterior (Processos no. 2016/19696-3 e 2018/02401-6), tornando possível a produção desta tese.

O presente trabalho foi realizado com apoio da Coordenação de Aperfeiçoamento de Pessoal de Nível Superior Brasil (CAPES). Desta forma, também agradeço à CAPES, pelo apoio recebido no início do doutorado (Processo no.1663589).

No meu caminho acadêmico até aqui encontrei pessoas que me incentivaram e a eles sou extremamente grata: meus professores, conselheiros e amigos: Valéria Zamataro, Luis Antônio Alves e, Fernando Kenji Nampo. Não por coincidência, nome de turma, patrono e paraninfo em minha graduação.

Amigos e pessoas queridas, aqui traria uma lista gigantesca, sem fim o carinho nela contido. Serei sucinta, mas isso não quer dizer que não há muito amor, ok?

Mariana Guimarães, Joice Amaral, Noemi Tarcha, Manuela Roediger, Renata Barbosa, Laís Fajersztajn, Michele Lacerda, trago aqui destaque para essa lista de mulheres maravilhosas. Vocês são as meninas que fazem meu coração sorrir! Aprendo tanto com cada uma de vocês, obrigada por fazerem do meu mundo um lugar mais feliz! Que eu sempre tenha oportunidade de agradecer e dizer o quanto eu amo vocês, o quanto gosto de compartilhar momentos de todos os tipos, porque somos assim: na alegria e na tristeza, podemos sempre contar umas com as outras! Obrigada, obrigada, obrigada!

Enrique Duim (meu irmão de sangue), obrigada por torcer por mim, saiba que te amo muito. Alexandre da Silva (meu irmão do coração) obrigada por se fazer presente 
na minha vida, por compartilhar momentos comigo, por me incentivar e sempre me fazer sorrir. Cara, você é muito especial na minha vida!

Não menos especiais tenho tanto carinho e admiração por outras meninas e meninos, professoras(es) queridas(os) que cruzaram meu caminho e torceram por mim e comigo em diferentes fases... Prof. Eliseu Waldman, Profa. Ana Paula Sayuri, Profa. Dirce Zanetta, Profa. Tatiana Toporcov, Prof. Fredi Quijano, Anne Slovic, Natalie Dantas, Isabela Martins, Tarsila Guimarães, Alessandra Garcia, Lissianne Veruska, Marcelo Moura, Laís Zacarelli, Luana Ferreira, Rafael Buralli, Mayara Longuini, Lucas Macedo, Adeylson Ribeiro, Tiago Canelas, Ricardo Goes de Aguiar, meus amados tios Luiz de Souza Assis Ribeiro, Jacira e João de Deus Neves.

I could never forget to thank my dear friends Brian, Gavin, Francesco, Zaheer, Caio, Florin (I miss you guys!).

Nestes quatro anos de doutorado aprendi tanto e recebi tanto da faculdade que foi minha casa! Como não ser grata pelas pessoas que fizeram tudo possível, tudo mais fácil, mais leve: Aguinaldo (com seu sorriso sincero e o melhor café do mundo!), querida Renilda Shimono, Angela Fernandes, Vânia do Santos Silva, Viviane Kiyan, Vanessa Fukuhara, todos sempre foram muito gentis comigo!!

Não poderia deixar de mencionar meu Miguel, companheiro lindo da minha vida, que foi fundamental nesse processo. Sempre me trouxe carinho, me lembrava a hora de começar e de parar de trabalhar com a fucinha mais linda desse mundo. Agradeço também ao Miguel (humano), que me acompanhou em grande parte desta jornada e sempre esteve para me apoiar!! Foi muito bom contar contigo!

Uau!! É tão bom olhar para trás e sentir-se inundada de carinho e felicidade. Essa é minha sensação agora!! Fechando um ciclo com a certeza de não importa o que a gente tem, mas QUEM a gente tem na vida!

E se me perguntarem se eu acredito em Deus, acho que a pergunta certa seria: Você acredita no amor?

Sim, acredito que todos nós podemos ser amor! 
Old age is like everything else. To make a success of it, you've got to start young". 
Duim, E. Envelhecimento e Funcionalidade: Uma Análise de Trajetórias

[Tese]. São Paulo: Faculdade de Saúde Pública, Universidade de São Paulo; 2020.

\section{RESUMO}

O envelhecimento é um processo heterogêneo e dinâmico, influenciado por características biológicas, psicológicas, hábitos de vida, características socioeconômicas e ambientais, às quais os indivíduos são expostos ao longo da vida. A partir da combinação de tais características podem ocorrer diferentes trajetórias de envelhecimento no que se refere ao comprometimento funcional. A funcionalidade física da pessoa idosa pode ser avaliada segundo sua condição de mobilidade e a capacidade de desempenhar atividades de vida. Objetivo: Avaliar a existência de múltiplas trajetórias de funcionalidade de pessoas idosas e verificar se os determinantes sociais de saúde estão associados com às trajetórias identificadas. Método: Esta tese é dividida em três estudos longitudinais que utilizam dados dos estudos Saúde, Bem-estar e Envelhecimento do Brasil e Chile e do Estudio Mexicano de Envejecimiento y Salud. Utilizou-se como base três desfechos de condição funcional: (i) atividades básicas de vida diária que são relacionadas ao autocuidado (alimentar-se, tomar banho, vestir-se, deitar e levantar da cama, usar o vaso sanitário e caminhar dentro de casa); (ii) atividades instrumentais de vida diária, associadas à vida em comunidade (utilizar meios de transporte, manejar o próprio dinheiro, preparar refeições, usar o telefone, lavar roupa, cuidar dos afazeres domésticos e controlar a própria medicação); e (iii) mobilidade. Enquanto exposições de interesse, os estudos que formam a tese avaliam o impacto dos determinantes sociais de saúde nas trajetórias de funcionalidade de idosos. Modelos de trajetória determinístico e probabilístico foram adotados para avaliar a evolução funcional dos participantes dos estudos. Após a definição ou extração dos grupos distintos de trajetórias modelos de regressão logística e regressão multinomial foram aplicados para avaliar os fatores associados ao pertencimento de cada trajetória. Resultados: $\mathrm{O}$ estudo 1 observou que indivíduos com menos de 4 anos de educação formal apresentaram 2,7 vezes a chance de vivenciar piores trajetórias de envelhecimento funcional em comparação com idosos com pelo menos oito anos de escolaridade. Foi observada ainda diferenças entre os países estudados, sendo que idosos residentes em São Paulo apresentaram maior probabilidade de pertencer a piores trajetórias funcionais em relação a idosos vivendo em Santiago (Odds Ratio (OR) 6,10, Intervalo de Confiança de 95\% (IC95\%) 3,55;10,49). O estudo 2 evidenciou seis trajetórias de funcionalidade. Idosos pretos e pardos apresentaram maior probabilidade de pertencer a uma trajetória com característica de acelerado processo de perda funcional em comparação com idosos brancos (OR 1,60; IC95\% 1,14; 2,26). Mulheres apresentavam maior chance de fazer parte das trajetórias 3 (Traj 3 OR 1,82; IC95\% 1,33;248), 4 (Traj 4 OR 2,14; IC95\%1,59;2,88) ou 5 (Traj 5 OR 1,95; IC95\% $1,41 ; 2,69)$ em relação à trajetória 2 quando comparadas com homens. Já o terceiro estudo que compõe a tese evidenciou a associação entre classes de condição socioeconômica e trajetórias de envelhecimento, sendo que quanto pior a condição social ao longo da vida maior a chance de fazer parte de piores trajetórias na velhice $(\mathrm{p}<0,001)$. Em todos os estudos apresentados, quanto maior a faixa etária maior a chance de fazer parte de piores 
trajetórias de funcionalidade. Conclusão: Os resultados apresentados evidenciam a heterogeneidade no processo de envelhecimento e sua relação com desigualdades sociais avaliadas por diferentes perspectivas. Ainda que guiado pela idade, o processo de envelhecimento em piores condições funcionais também pode ser explicado por baixo nível de escolaridade, pelo fato de ser mulher, ser preto ou pardo e por outras características socioeconômicas que posicionam a pessoa idosa em situação de desvantagem durante o processo de envelhecimento. Os presentes achados reforçam a discussão das desigualdades sociais e o envelhecimento em si dentro de uma perspectiva de curso de vida.

Palavras-chave: Envelhecimento; Incapacidade funcional; Desigualdades sociais; Estudo longitudinal; Curso de vida 
Duim, E. Ageing and Functioning: A trajectory analysis [Thesis]. São Paulo: Faculdade de Saúde Pública, Universidade de São Paulo; 2020.

\section{ABSTRACT}

Aging is a heterogeneous and dynamic process, influenced by biological, psychological, lifestyle, socioeconomic and environmental characteristics that individuals are exposed throughout life. From the combination of such characteristics, different aging profiles can occur with regard to functional impairment. The physical functioning of the elderly person can be assessed according to their condition of mobility and the ability to perform life activities. Objective: To evaluate functional trajectories of elderly people and to verify the effect of social determinants of health on these trajectories. Method: This thesis consists of three longitudinal studies, using data from the Health, Well-Being and Aging studies in Brazil and Chile and from the Mexican Health and Aging Study. Three functional outcomes were used as a basis: (i) basic activities of daily living that are related to self-care (eating, bathing, dressing, lying down and getting out of bed, using the toilet and walking inside home); (ii) instrumental activities of daily living, associated with community life (using means of transport, handling one's own money, preparing meals, using the telephone, washing clothes, taking care of household chores and controlling one's medication); and (iii) mobility. As independent characteristics of interest we focused on social determinants of health and its linked with trajectories of functioning of older adults. Deterministic and probabilistic trajectory models were adopted to assess the functional evolution of the study participants. After defining or extracting the distinct groups of trajectories, logistic and multinomial regression models assessed unadjusted and adjusted associations between the trajectories and covariates. Results: The study 1 observed that individuals with less than 4 years of formal education had 2.7 times the chance of experiencing worse functional trajectories compared to older people with at least eight years of schooling. Differences were also observed between the countries studied, with individuals living in São Paulo - Brazil being more likely to belong to worse functional trajectories than those living in Santiago - Chile (Odds Ratio (OR) 6,10, 95\% Confidence Interval (95\% CI) \%) 3.55; 10.49). The study 2 showed six trajectories of functioning. Black and brown older people were more likely to belong to a trajectory with an accelerated functional loss process compared to white elderly people (OR 1.60; 95\% CI $1.14 ; 2.26$ ). Women were also more likely to be assigned to trajectories 3 (Traj 3 OR 1.82; 95\% CI 1.33;2.48), 4 (Traj 4 OR 2.14; 95\% CI 1.59;2.88) and 5 (Traj 5 OR 1.95; 
95\% CI 1.41;2.69) than to the Functional Trajectory (Traj. 2) in comparison to men. The study 3 showed the association between classes of socioeconomic condition and aging trajectories, the worse the social condition throughout life the greater the chance of being part of the worst trajectories in old age $(\mathrm{p}<0,001)$. In all the three studies, the older the individual, the higher the likelihood to be assigned to worse functional trajectories. Conclusion: The results presented show the heterogeneity in the aging process and its relationship with social inequalities assessed by different perspectives. Although guided by age, the aging process in worse functional conditions can also be explained by low level of education, by the fact of being a woman, being black or brown and by other socioeconomic characteristics that place the elderly person at a disadvantage during the aging process. The present findings reinforce the discussion of social inequalities and aging itself within a life course perspective.

Keywords: Aging; Functional disability; Social differences; Longitudinal study; Life course 


\section{SUMÁRIO}

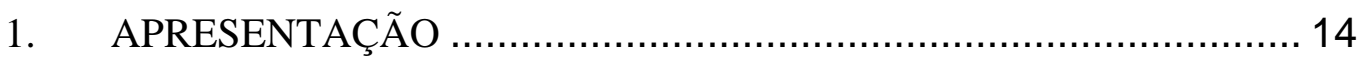

2. INTRODUÇÃO .................................................................... 15

2.1 FUNCIONALIDADE AO ENVELHECER SOB A ÓTICA DO

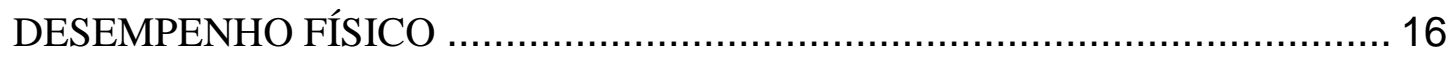

2.2 ENVELHECIMENTO COMO UM PROCESSO AO LONGO DA

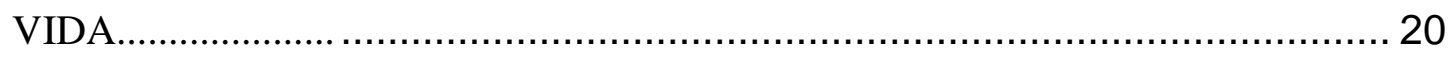

2.3 DETERMINANTES SOCIAIS DE SAÚDE AO LONGO DA VIDA 24

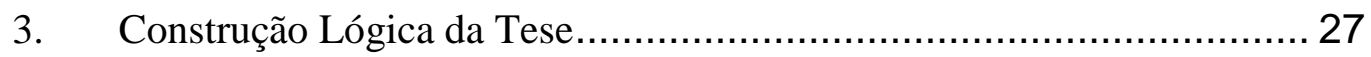

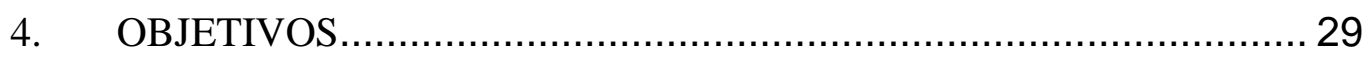

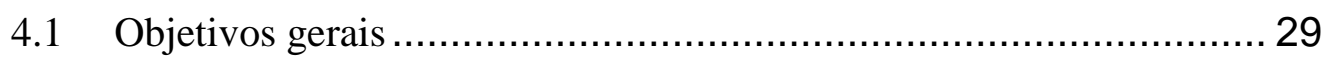

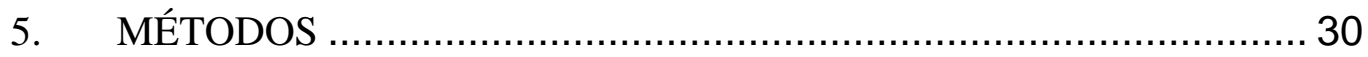

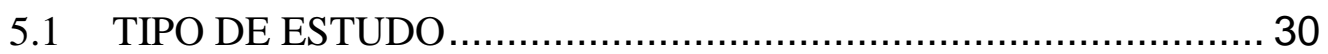

5.2 AMOSTRA, LOCAL E PERÍODO DA PESQUISA ......................... 30

5.3 VARIÁVEIS DOS ESTUDOS ........................................... 30

5.3 ANÁLISE ESTATÍSTICA …............................................ 31

5.5 CONSIDERAÇÕES ÉTICAS ....................................... 34

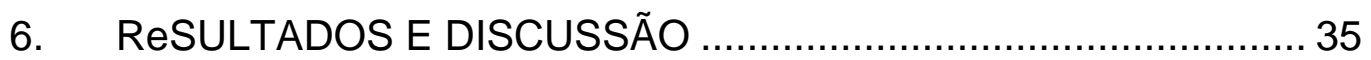

Artigo 1: Cumulative Inequalities: is age a leveler? The case of functional trajectories of older adults in two middle-income countries ........................ 35

Artigo 3 - Highways to Ageing - Linking life course SEP to multivariate trajectories of health outcomes in older adults .................................. 81

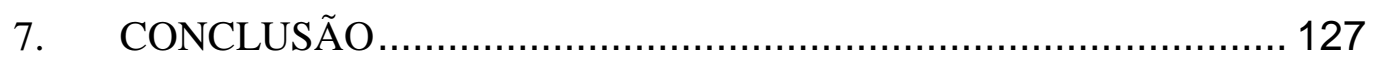

REFERÊNCIAS BIBLIOGRÁFICAS ........................................... 128

ANEXO I - APROVAÇÃO COMITÊ DE ÉTICA EM PESQUISA.......... 136

APÊNDICE 1 - COMPROVANTE DE SUBMISSÃO DO ARTIGO $1 . .142$ APÊNDICE 2 - COMPROVANTE DE SUBMISSÃO E ACEITE DO

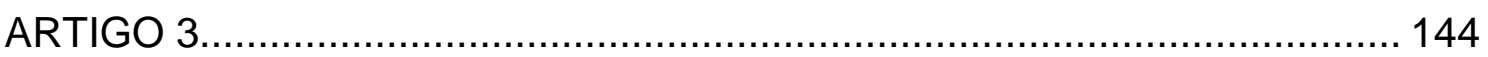


APÊNDICE 3 - CURRÍCULO LATTES - ETIENNE DUIM 1466 APÊNDICE 4 - CURRÍCULO LATTES PROFESSOR JOSÉ LEOPOLDO FERREIRA ANTUNES 


\section{APRESENTAÇÃO}

A tese de doutorado intitulada "Envelhecimento e Funcionalidade: uma análise de Trajetórias" foi estruturada no formato coletânea de artigos científicos. Tem como objetivo avaliar a progressão temporal de desfechos relacionados ao desempenho funcional em populações de idosos. Utilizando modelos estatísticos para análise de dados longitudinais, apresento três artigos que evidenciam a heterogeneidade do envelhecer em populações de idosos residentes no Brasil, Chile e México.

Para tentar compreender e explicar os resultados encontrados nas trajetórias de envelhecimento, retomo conceitos da epidemiologia curso de vida, com especial interesse nos determinantes sociais de saúde, suas interfaces e impactos na velhice.

Os três artigos que compõem a tese também discorrem sobre minha trajetória acadêmica. Durante o doutorado, realizei dois estágios no exterior, um no Chile (Escuela de Salud Pública - Universidade del Chile) e outro na Holanda (Faculty of Health, Medicine and Life Science - Maastricht University), e em ambas as ocasiões pude desenvolver habilidades acadêmicas e pessoais. Não menosprezo o período que estive no Brasil e acredito que tenha sido de grande valia a experiência no exterior para também valorizar o trabalho de pesquisadoras e professoras que me ensinaram com dedicação ímpar. Também ressalto a influência que meu orientador teve sobre minha formação, sempre acolhedor, me aconselhou e direcionou em diversos momentos, sempre com muita paciência e a porta de sua sala sempre aberta.

Contar uma trajetória de intenso aprendizado ao longo de quatro anos não é fácil, mas o grande desafio é costurar a essência deste aprendizado em artigos densos em informação e ricos em detalhes.

Na seção Método, discorro sobre aspectos metodológicos de cada um dos artigos apresentados (tipo de estudo, local e período da pesquisa, população, procedimentos utilizados para coleta de dados, variáveis do estudo, análise estatística e aspectos éticos).

Os artigos configuram a seção Resultados e Discussão. As conclusões são apresentadas na parte final dessa tese e buscam responder aos objetivos propostos. 


\section{INTRODUÇÃO}

O processo de envelhecimento de uma sociedade ocorre em velocidades diferentes no mundo, sendo observado de maneira acelerada e sem precedentes no Brasil e em outros países das Américas ${ }^{1,2}$. Na última década houve aumento de 45,9\% na população acima de 59 anos. Em 2005 a proporção de idosos era de 9,8\%, correspondendo a 14,3\% da população brasileira em 2015. Estima-se que em 2050, o contingente de idosos brasileiro representará $30 \%$ da população e em 2070 estima-se que o Brasil apresente uma proporção de idosos maior do que a proporção em outras regiões do mundo (Figura 1) ${ }^{1}$.

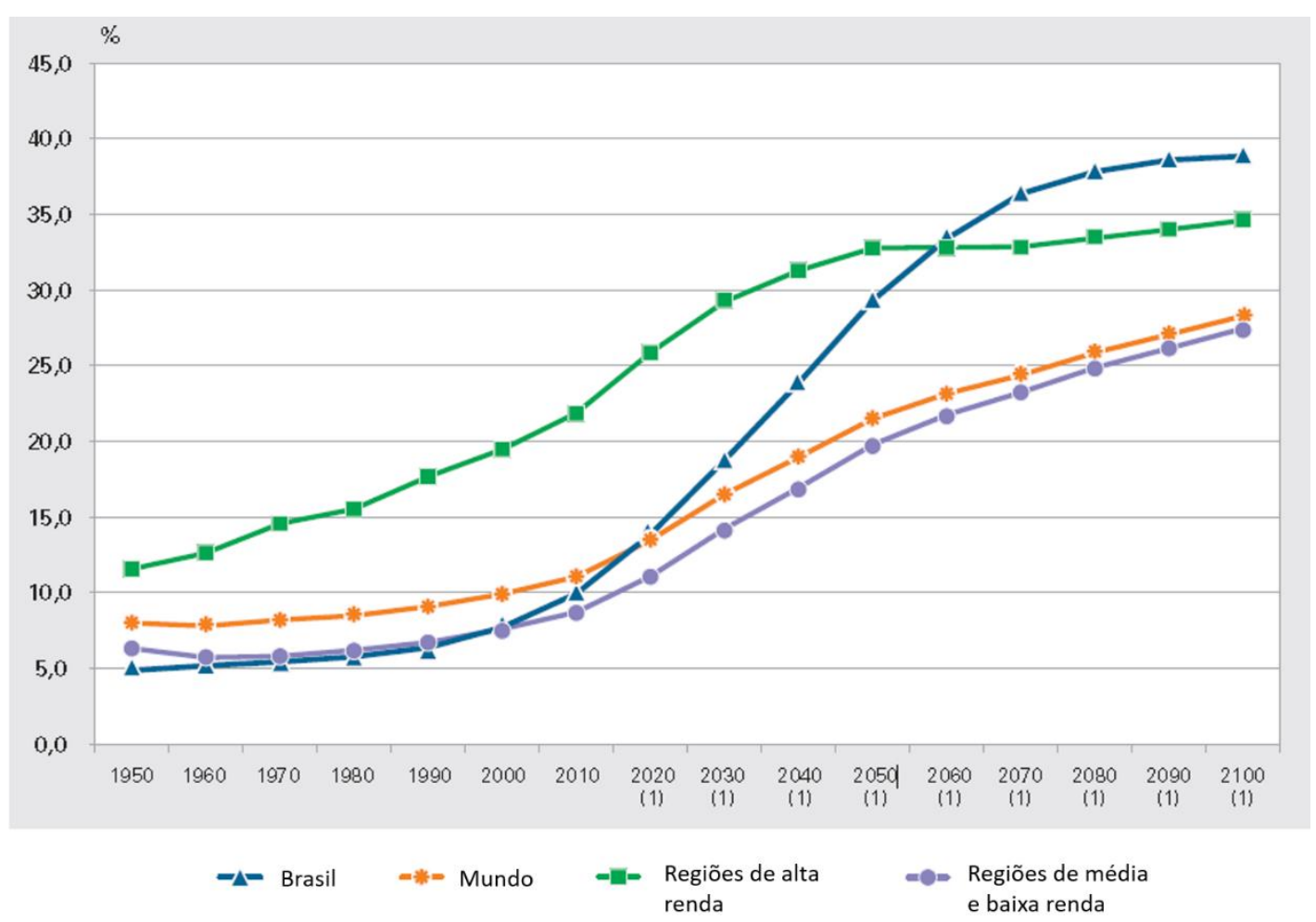

Figura 1. Proporção de pessoas de 60 anos ou mais de idade na população total - Mundo - 1950/2100.

Fonte: Population indicators. In: World population prospects: the 2015 revision. New York: United Nations, Department of Economic and Social Affair, Population Division, 2015.

A mudança na estrutura etária, observada nas últimas décadas em países de média renda, é resultado da queda na taxa de fecundidade e subsequente aumento na expectativa de vida, com variações expressivas entre e mesmo dentro dos países que vivenciam este processo ${ }^{3}$. Resguardada por melhorias em condições de saúde, saneamento básico, nutrição e tecnologias, a mudança na 
estrutura etária apresenta-se acelerada, não apenas com o aumento na proporção de idosos na sociedade, mas também com o aumento da sobrevida desse grupo etário. A transição demográfica nos países em desenvolvimento das Américas vem sendo acompanhada por uma transição epidemiológica, com aumento das morbidades crônicas e consequente aumento dos anos vividos com incapacidade ou perdidos por mortalidade precoce ${ }^{4}$. Quando estudada, a transição epidemiológica relacionada a morbidades em populações mais envelhecidas deve-se considerar não apenas as doenças crônicas. Atentar-se para a influência da transição epidemiológica na funcionalidade dos indivíduos é fator relevante para compreender como tais mudanças somadas exigem novos olhares frente a adequação de prioridades econômicas, sociais e políticas em relação à população idosa. Compreender os percursos relacionados à funcionalidade ao longo da vida, em especial na velhice, ajuda a esclarecer a heterogeneidade do envelhecer e o aumento da complexidade de cuidado relacionada a idades avançadas ${ }^{2}$.

O conhecimento dos padrões de saúde, doença e funcionalidade que permeiam o processo de envelhecimento pode possibilitar o delineamento mais assertivo de condutas na atenção à saúde da população em diferentes fases do envelhecer ${ }^{5}$.

\subsection{DESEMPENHO FÍSICO AO ENVELHECER SOB A ÓTICA DA} FUNCIONALIDADE

De acordo com Wolinsky e colaboradores (2000), a funcionalidade é um tradicional objeto de estudo na geriatria e gerontologia, seja pela quantidade de estudos que avaliam limitação funcional e incapacidade; seja pelo número de instrumentos desenvolvidos para assegurar a qualidade da avaliação de tais desfechos ${ }^{6}$. A funcionalidade é descrita pela Classificação Internacional de Funcionalidade, Incapacidade e Saúde ${ }^{7}$ com base em um conceito biopsicossocial, considerando aspectos estruturais e de função corporal, que possibilitam execução de uma atividade frente ao potencial máximo individual em um ambiente padronizado (capacidade funcional), e que, uma vez moderados por aspectos ambientais e sociais, permitem a avaliação do desempenho de atividades que reflete a possibilidade de participação do indivíduo no meio que o rodeia (desempenho funcional). Ao avaliar a limitação ou restrições de funcionalidade estima-se medir a discordância entre o desempenho observado e o esperado, sendo o segundo a norma populacional ${ }^{7}$. Dessa forma, notamos que a sociedade também tem grande influência na avaliação 
de funcionalidade de idosos. E ainda que esta avaliação se baseie na percepção da própria pessoa idosa sobre seu desempenho, de fato trata-se de uma avaliação mediada por conceitos e expectativas sociais, além de facilitadores ou barreiras ambientais que possam super- ou subestimar a execução de atividades e a participação social, além de facilitadores ou barreiras ambientais.

As capacidades funcionais são adquiridas e desenvolvidas durante a infância e adolescência e declinam com o avanço da idade, influenciadas por doenças, acidentes ou características sociocontextuais, podendo ultrapassar o limiar de incapacidade de modo precoce ou retardado. A partir dos 30 anos, observa-se a diminuição do ritmo de aquisições de habilidades físicas, resultado de adaptações fisiológicas ${ }^{8}$. Habilidades relacionadas à função física podem variar de maneira heterogênea a partir da quinta década de vida ${ }^{9}$. O processo de perda gradual das capacidades de executar funções cotidianas, relacionadas ao autocuidado e à convivência em sociedade, pode apresentar inícios e trajetórias distintas, a depender de características de vida e saúde dos indivíduos ${ }^{8}$. E essas possibilidades não são unicamente dependentes da idade ${ }^{10}$.

Nota-se o interesse de identificar por quais caminhos a evolução funcional na velhice acaba por gerar vários graus de limitação e dependência, podendo evoluir para perda de autonomia e até mesmo a morte ${ }^{5,11,12}$. Para tanto, são propostos diferentes modos de se avaliar a funcionalidade, com grande atenção sendo dispensada ao estudo de padrões de limitações e incapacidades ${ }^{13}$. Os diferentes modos apresentados resguardam em si pontos positivos e negativos a serem mencionados a seguir.

Ao optar pela avaliação da capacidade funcional, considera-se a capacidade de realizar determinada ação em ambiente padronizado, minimizando a interferência do contexto ${ }^{7}$. Ainda que controle os fatores externos, o ambiente padronizado apresenta diferenças significativas frente àquele em que a pessoa idosa está habituada a desempenhar suas funções. A avalição da capacidade funcional pode, dessa forma, mascarar dificuldades reais, restrições e adaptações realizadas para manutenção da independência no cotidiano ${ }^{14} \mathrm{e}$, por isso, acaba sendo pouco utilizada em estudos observacionais.

Outra maneira de avaliar o nível de funcionalidade física é por meio do desempenho de atividades, seja de forma aferida (solicitando ao indivíduo que execute a atividade proposta) ou 
referida (perguntando sobre o desempenho de tal função). Nesse caso, o indivíduo é avaliado em ambiente familiar, considerando aspectos ambientais que favoreçam ou dificultem a realização das atividades em questão ${ }^{7}$. O resultado de tal avaliação permite ponderar adaptações e dificuldades reais, ainda que não possibilite avaliar potencial máximo individual (como no caso da aferição da capacidade funcional).

Considera-se a aferição direta da capacidade ou desempenho como sendo um recurso mais acurado para a avaliação do estado funcional dos idosos, uma vez que um profissional treinado pode julgar adequação e qualidade do movimento, assim como o tempo de execução. Estudos que investigam trajetórias de funcionalidade e optam pela avaliação de desempenho aferido acabam por utilizar testes padronizados, como o caso do Short Physical Performance Battery (SPPB), que avalia força e habilidade de membros inferiores ${ }^{15,16}$.

No entanto, esta aferição pode implicar em elevado custo e dificuldades operacionais que limitem a utilização. Como alternativa, o desempenho referido é um método menos custoso e de fácil aplicabilidade. Ainda assim, deve-se ressaltar que esse pode ser fonte de viés, devido a falhas de memória, super- ou subestimação da capacidade, ou desvalorização da mesma no caso de respostas coletadas indiretamente (respondente substituto) ${ }^{17}$.

Dentro do espectro de possibilidades para avaliação funcional de idosos, $\mathrm{Katz}^{18}$ e Lawton ${ }^{19}$ consagraram-se por proporem avaliação do desempenho funcional baseado em dois grupos de atividades realizadas no dia-a-dia. As atividades cotidianas, ou AVD, são divididas conceitualmente em atividades básicas de vida diária (ABVD), atividades instrumentais de vida diária (AIVD). As ABVD estão relacionadas diretamente com o autocuidado. A dificuldade em realizar esse tipo de atividade implica em risco para a manutenção de sua independência, pois essas atividades são relacionadas à sobrevivência do indivíduo: alimentar-se, tomar banho, vestir-se, deitar e levantar da cama, usar o vaso sanitário e caminhar pequenos percursos dentro de casa ${ }^{20}$.

As AIVD relacionam-se com a capacidade de desempenhar atividades que permitam ao indivíduo conviver em sociedade ${ }^{20}$. Este grupo de atividades é mais complexo que o anterior, relaciona-se com ter a iniciativa e desempenhar funções como: utilizar meios de transporte, preparar refeições, cuidar de afazeres domésticos, manejar o próprio dinheiro, lavar roupa, usar telefone e controlar a própria medicação ${ }^{19}$. 
Em inquéritos populacionais estudos de coorte é comum a utilização de instrumentos pautados em desempenho autorreferido para avaliar funcionalidade para AVD ${ }^{17}$, a exemplo dos índices propostos por Katz, Lawton, ou mesmo versões adaptadas ${ }^{21-25}$.

Considerar a funcionalidade em relação à habilidade em executar as atividades cotidianas pode propiciar a avaliação do idoso dentro de contexto mais amplo, um avanço ao modelo biomédico de avaliação convencional do indivíduo, centrado exclusivamente na doença ${ }^{13,26}$. Desta forma, o impacto das condições clínicas e patológicas de um indivíduo pode ser atenuado por adaptações realizadas pelo mesmo, no intuito de manter-se independente 13,27,28. Pesquisas longitudinais de múltiplos períodos podem levar à identificação de subgrupos de idosos com padrões similares de transição do desfecho, permitindo, assim, avaliar os fatores associados a fazer parte de um determinado subgrupo em detrimento de outro ${ }^{29,30}$. Como consequência final, estudos de trajetória possibilitam a proposição de ação mais assertivas de acordo com necessidades específicas ${ }^{6}$.

O modo pelo qual a avaliação será procedida estará diretamente associada ao tipo de estudo, tempo destinado para realização do mesmo e planejamento financeiro da pesquisa. Diferentes testes e questionários destinam-se a avaliar a funcionalidade de idosos ${ }^{31-33}$. A escolha do melhor instrumento para a avaliação de funcionalidade relaciona-se com o tipo de estudo, tempo destinado para realização do mesmo, planejamento financeiro da pesquisa e os objetivos de pesquisa.

No final da década de 1990, Stuck et al. ${ }^{34}$ publicaram uma revisão sistemática compreendendo 78 estudos longitudinais que avaliaram fatores associados à transição funcional. Os fatores observados naquele momento eram relacionados a condições de saúde, como comprometimento cognitivo, doenças crônicas, depressão, pior percepção de saúde, e a hábitos de vida, como pratica de atividade física reduzida, baixos níveis de contatos sociais, habito de fumar, entre outros. Não foram investigados ou reportados a influência da escolaridade, renda classe social na transição funcional de idosos ${ }^{34}$. O aumento no número de estudos longitudinais de múltiplas coortes, assim como desenvolvimento de modelos estatísticos compatíveis, favoreceram a investigação da evolução temporal da funcionalidade de pessoas idosas, assim como ampliou-se a investigação sobre possíveis fatores de risco ${ }^{21,35,36}$. 
Keeney et al. ${ }^{37}$ acompanharam a evolução funcional idosos ao longo de 5 anos (5 ondas) por meio do autorrelato de dificuldade para realizar AVD. Obtiveram como resultado três trajetórias funcionais, uma indicando estabilidade e baixo nível de comprometimento funcional, a segunda trajetória identificada como de declínio gradual e, por fim, uma trajetória de rápido declínio das habilidades funcionais referidas ${ }^{37}$. Gill et al. ${ }^{25}$ avaliaram funcionalidade referida, utilizando questões sobre habilidade de performar atividades de autocuidado (alimentar-se, trocarse, banhar-se e realizar higiene pessoal no banheiro). Foram identificados cinco grupos com distintas trajetórias, elencadas como 1) trajetória sem incapacidade, 2) trajetória catastrófica, 3) incapacidade acelerada, 4) incapacidade progressiva e 5) incapacidade severa e persistente.

Ao longo de três e quatro follow-ups, Ahmed et al. ${ }^{16} \mathrm{e}$ Mutambudzi et al..$^{15}$, respectivamente, identificaram três trajetórias de comportamento funcional aferido em cada estudo. As caracterizações das trajetórias foram similares, sendo elas: 1) trajetória de estabilidade e alta nível de desempenho funcional, 2) trajetória de declínio gradual e 3) trajetória de acelerado processo de declínio funcional.

Observar a evolução temporal da funcionalidade de pessoas idosas é aspecto central para melhor compreensão de padrões de mudança ocorrendo ao longo do tempo. A ideia de identificar grupos latentes de indivíduos, ou seja, grupos não diretamente observáveis, que compartilham o mesmo percurso segundo evolução de um desfecho estabelecido vai além de trazer uma análise taxonômica ou de simples agrupamento. As análises de trajetória chamam atenção para a discussão das causas e consequências relacionadas a diferentes evoluções e instigam proposição de intervenções capazes de promover mudanças ${ }^{38}$.

\subsection{ENVELHECIMENTO COMO UM PROCESSO AO LONGO DA VIDA}

Ao mencionar causas e consequências direta ou indiretamente associadas ao desempenho funcional de idosos, deve-se considerar que o envelhecimento é um processo que se desenvolve ao longo de toda a vida ${ }^{28,39}$. Dessa forma, não se deve ignorar aspectos de vida pregressa quando analisamos grupos de indivíduos que vivenciam processos diferenciados de envelhecimento. BenShlomo e colaboradores ${ }^{40}$ sublinharam essa diretriz com a proposição de um enfoque 
epidemiológico que integre o indivíduo frente a sua trajetória de vida, expandindo limites, propondo o estudo do efeito a longo prazo de processos biológicos, comportamentais e psicossociais que se relacionam, em diferentes níveis, ao processo de envelhecimento e ao comprometimento da saúde e qualidade de vida de idosos.

Essa teia de relações implementa-se mediante exposições sociais e ambientais, construídas ao longo dos anos, desde a gestação, passando pela infância, adolescência e vida adulta ${ }^{40-44}$. Lynch $^{45}$ ressalta que "a perspectiva ao longo da vida explicitamente reconhece que para relações entre raça, condições socioeconômicas e saúde não existe um vácuo sócio-histórico". Avaliar a pessoa idosa considerando aspectos de vida pregressa imprime complexidade à análise e traz uma visão consistente do envelhecer, tendo por base as interrelações que permeiam o curso da vida, como a intersecção de riscos ambientais, sociais e individuais ${ }^{46}$.

Considerando este olhar epidemiológico ampliado, pesquisas e modelos conceituais têm se desenvolvido no intuito de verificar como ocorre a evolução de doenças ou condições de saúde durante o envelhecimento. Segundo Blane ${ }^{47}$, o interesse na compreensão de como as experiências ao longo da vida são capazes de influenciar o modo como envelhecemos e os impactos na saúde dos indivíduos estimulou o desenvolvimento de diferentes abordagens teóricas e metodológicas. Acontecimentos no curso da vida, restritos a períodos específicos acabam tendo impacto em diferentes fases de vida ${ }^{47}$.

O desenvolvimento da linha de pesquisa de "epidemiologia do curso de vida" ao longo das últimas décadas (Figura 2) converge com a crescente necessidade de pesquisadores de diferentes áreas de compreender melhor os processos de envelhecimento. 


\section{Epidemiologia de Curso de Vida e Envelhecimento}

\section{Fase 1:}

Estudos seminais sobre Origem Fetal de Doenças no Adulto tinha como ênfase no estudo de como exposições em estágios iniciais da vida poderiam associar-se com doenças na vida adulta.

\section{Fase 2:}

Estudos sobre a função

fisiológica e o progresso natural no decorrer da vida, e como fatores de risco psicológicos e sociais poderiam estar associados, agindo de modo cumulativo ou sinérgico em diferentes fases da vida.

\section{Fase 3:}

Com o desenvolvimento de estudos longitudinais e o desenvolvimento de métodos sofisticados que possibilitaram análise de dados, a terceira fase na qual aplica-se as teorias de curso de vida para o estudo do envelhecimento.

Figura 2. Desenvolvimento da Epidemiologia de Curso de Vida e convergência para o estudo do envelhecimento.

Fonte: Ben-Shlomo, Cooper \& Kuh, $2016^{40}$.

Dentre os modelos teóricos que buscam explicar as relações entre exposições no curso de vida e desfechos tardios de saúde, reside a ideia de que processos biológicos, comportamentais e sociais de longo termo estão associados com desfechos tardios de saúde, predisposição a alteração de mecanismos biológicos que levem ao adoecimento, ou mesmo com o aumento no risco de comprometimento funcional e morte ${ }^{48}$.

Teorias relacionadas com acumulação de riscos são bem aceitas entre pesquisadores em gerontologia e geriatria. Três linhas de pesquisa distintas devem ser mencionadas como precursoras ou como teorias centrais, a partir das quais (e com a constante evolução das mesmas) outros discursos emergem na tentativa de melhor explicar os processos de envelhecimento ao longo da vida ${ }^{44,47}$, são elas: i. Modelo de Acumulação de Riscos, ii. Modelo de Período Crítico/Sensível, iii. Modelo da Idade como Niveladora.

O Modelo de Acumulação de Riscos envolve a aquisição gradual e somatória de episódios ou exposições (de curto ou longo prazo) modulam uma das linhas teóricas sobre processo acumulativo. Esse modelo baseia-se em duas diretrizes. A primeira diretriz, conhecida como 
Tendência Sistêmica, versa sobre como aspectos sociais direcionam o acúmulo de vantagens ou desvantagens considerando desde interações no âmbito individual, assim como no nível organizacional da sociedade. A segunda diretriz definida pelo modelo de acumulação de riscos é basicamente estrutural, no qual as posições sociais são consideradas estruturas operando para além do indivíduo. Essas duas diretrizes operam de tal forma que "a posição social de um indivíduo em um estágio da vida influencia sua seguinte posição, implicando em uma dependência sistêmica das posições sociais subsequentes no curso de vida" ${ }^{" 39}$.

Atualmente considerada uma vertente do modelo de acumulação de riscos ${ }^{40}$, o Modelo de Período Crítico/Sensível postula que as diferenças relacionadas ao exato momento em que determinadas exposições ocorrem devam ser consideradas. Isso porque, o acúmulo simples (soma de riscos sem fator de correção) pode não ser suficiente para conter a força do efeito de uma exposição ocorrendo em período sensível, ou a qualidade do efeito, quando ocorrida em período crítico.

Estes dois modelos - o de acúmulo e o de período crítico - reforçam que acontecimentos ao longo da vida, geralmente estruturados por características sociais afetam o processo de envelhecimento. $\mathrm{O}$ terceiro modelo mencionado neste capítulo traz uma perspectiva diferenciada. Age as Leveler (Idade como nivelador) defende que vantagens e desvantagens acumuladas ao longo da vida tendem a ser minimizadas dentro da perspectiva do envelhecimento; sendo assim, características biológicas do processo de envelhecimento tornam-se mais relevantes do que exposições acumuladas ao longo da vida. Esta teoria baseia-se também em políticas públicas de cuidado com a pessoa idosa, seja por meio da atenção básica à saúde desta população, pagamento de aposentadorias e pensões, as quais acabam por nivelar algumas disparidades observadas ao longo da vida ${ }^{49}$. Por outro lado, deve-se considerar que a mortalidade acaba por ser um importante fator nivelador, uma vez que indivíduos que vivenciam desigualdades sociais e de saúde ao longo da vida tendem a morrer precocemente ${ }^{49}$.

Como mencionado anteriormente, uma miríade de teorias e hipóteses baseiam-se nos referidos modelos sobre as relações entre curso de vida e envelhecimento. Todas, em maior ou menor grau, discutindo como as estruturas e os aspectos sociais acabam por influenciar a saúde da população ao longo da vida. 


\title{
2.3 DETERMINANTES SOCIAIS DE SAÚDE AO LONGO DA VIDA
}

Em 2004, a Organização Mundial de Saúde postulou que:

\begin{abstract}
"As condições sociais nas quais as pessoas vivem influenciam poderosamente suas chances de serem saudáveis. De fato, fatores como pobreza, exclusão social e discriminação, moradia inadequada, condições insalubres para a primeira infância e baixo status ocupacional são determinantes importantes da maioria das doenças, mortes e desigualdades na saúde entre e dentro de países." 50
\end{abstract}

As probabilidades de sobreviver e envelhecer de modo saudável são fortemente associadas com as condições socioeconômicas e familiares ${ }^{51,52}$ às quais os idosos estiveram expostos ao longo da vida. Destaque deve ser dado que, passados 30 anos, um dos grandes desafios da sociedade como um todo continua sendo aumentar as possibilidades para que indivíduos mais submetidos à privação material possam viver uma vida saudável ${ }^{53}$. Educação, situação econômica e exclusão social estão contemplados entre fatores que afetam negativamente a vida e saúde das pessoas.

As condições/características vida e trabalho, sendo elas escolaridade, raça, sexo, nível de renda, local de residência, hábitos sociais, devem ser consideradas como determinantes de saúde, em especial para população idosa ${ }^{43,44,54-57}$. Em países de média renda, educação, renda, sexo e raça figuram como fatores socioeconômicos que influenciam desfechos, o uso e acesso aos serviços necessários à saúde na velhice ${ }^{58-61}$. Torres e colaboradores ${ }^{62}$ ainda reforçam que os determinantes sociais a que foram submetidos ao longo da vida repercutem de maneira pontual e permanente durante o processo de envelhecimento.

Diversos estudos constataram maior longevidade entre as mulheres, no entanto o fato de terem tido oportunidades distintas no que diz respeito à educação e trabalho, as idosas vivem em piores condições de saúde e funcionalidade em relação aos homens acima de 59 anos ${ }^{54,63-66}$. Este dado é sustentado por Zimmer e colaboradores ${ }^{67}$, assim como por Ahmed et al ${ }^{16}$, em análise da evolução de desempenho funcional de idosos ao longo do tempo. Por meio de as análises de trajetória estratificadas por sexo foi possível sumarizar três achados principais: 1) maior frequência de mulheres idosas em ambos estudos em relação aos homens idosos; 2) elas apresentavam piores condições funcionais no início dos seguimentos em relação aos homens e 3) esses tiveram melhores evoluções dos desfechos relacionados à limitação ao longo do tempo ${ }^{16,67}$. 
Outras características sociodemográficas e econômicas como raça/cor da pele e nível de escolaridade também são fatores que ponderam as oportunidades de vida adulta, possibilidades de escolhas do ponto de vista de hábitos de vida e saúde, impactando por fim na heterogeneidade do envelhecer 10,66,68,69. Em países que apresentam grandes disparidades econômicas e desigualdades, observa-se rigidez nas estruturas sociais que por sua vez dificultam a quebra do ciclo relacionado ao acúmulo de vantagens por uns em detrimento das desvantagens de outros. E este ciclo muitas vezes não é nem sequer nivelado pela idade, uma vez que estudos de trajetória indicam mecanismos sociais direcionando trajetórias de acumulo de incapacidades e limitações entre idosos a depender do sexo, raça e etnia ${ }^{70}$. Com relação aos determinantes econômicos e sociais geralmente avaliados em relação à fase infanto-juvenil, Haas e colaboradores ${ }^{10}$ e Pakpahan et al ${ }^{68}$ conseguiram vincular circunstâncias de vida pregressa e a história funcional - ou seja, trajetórias funcionais de indivíduos que foram acompanhados frente a mudança na capacidade de desempenhar atividades cotidianas - na velhice. Nesse estudo, a condição socioeconômica durante a infância mostrou-se como fator associado ao nível de limitação funcional no início do seguimento, assim como implicou na evolução para limitação funcional nos diferentes subgrupos avaliados.

Ao vincular teorias de curso de vida e de determinantes sociais de saúde torna-se mais fácil a compreensão do processo de envelhecimento para além dos aspectos fisiopatológicos a ele relacionados. Uma vez que os determinantes demográficos e socioeconômicos são fatores causais (diretos ou indiretos) de desfechos em saúde, estes devem ser considerados como influenciadores da história de vida e curso da velhice ${ }^{56,71,72}$.

Assim, saúde, doença e funcionalidade na pessoa idosa devem ser consideradas sob a influência de aspectos demográficos, sociais, econômicos e contextuais ao longo da vida ${ }^{44}{ }^{73}$. Incorporar tais características na avaliação de coortes de idosos pode evidenciar os caminhos pelos quais determinantes sociais de saúde influenciam aspectos funcionais na velhice. A contemplação do indivíduo dentro das peculiaridades que cada momento da vida implica é um desafio que vem sendo aceito por muitos pesquisadores. Muitos pesquisadores lançam mão de metodologias de curso de vida para verificar os impactos que exposições sociais trazem no decorrer do processo de envelhecimento. Entre esses estudos, destacam-se análises de trajetórias com direcionamento para epidemiologia de curso de vida ${ }^{21,62,74-76}$. 
O presente estudo justifica-se frente ao fato de que o acompanhamento das mudanças de desfechos funcionais ao longo do tempo permite identificar subgrupos de risco e estimar momentos propícios para a ação, nos quais intervenções oportunas possam reverter ou retardar processos de limitação funcional. Avaliar trajetórias de desempenho funcional tendo como premissa o impacto de determinantes sociais de saúde permite contemplar a história de vida de populações idosas. Por fim, a comparação de processos de vida e envelhecimento entre idosos de diferentes países e sujeitos a diferentes conjuntos de normas sociais e regulamentações sensibilizam o olhar do pesquisador frente a determinantes sociais de saúde e inspiram para proposição de mudanças necessárias. 


\section{CONSTRUÇÃO LÓGICA DA TESE}

A presente tese visou analisar o envelhecimento como um processo ao longo da vida e identificar como determinantes sociais de saúde influenciam tardiamente trajetórias de desempenho funcional de idosos.

As oportunidades acadêmicas durante o doutorado possibilitaram parcerias em diferentes países, como resultado é apresentado coletânea de três artigos que versam sobre trajetórias de funcionalidade de idosos residentes em três países Latino Americano.

O primeiro artigo - Cumulative Inequalities: is age a leveler? The case of functional trajectories of older adults in two middle-income countries - é uma conversa entre Brasil e Chile. Utilizando a base de dados do Estudo Saúde, Bem-Estar e Envelhecimento (Estudo SABE), estudo longitudinal de base populacional, conduzidos em São Paulo e Santiago, compara-se as possíveis trajetórias funcionais de idosos acompanhados ao longo de 11 anos. O objetivo principal nesse estudo foi verificar o impacto da educação nas trajetórias funcionais de idosos de ambos os países, assim como identificar as diferenças entre os países que vivenciam acelerado processo de envelhecimento e políticas públicas no âmbito da saúde e educação distintos.

O artigo Functional Trajectories and Social Determinants of Health of Brazilian Older Adults debruça-se sobre a população brasileira, tendo como amostra os idosos residentes em São Paulo e participantes do Estudo SABE. Utilizando modelo probabilístico para revelar agrupamento de indivíduos com trajetórias similares de desempenho funcional, é possível verificar a heterogeneidade do envelhecer. Nesse artigo, é possível acompanhar a interdependência entre atividades básicas e instrumentais de vida diária (modelo de multitrajetória). Elencou-se como objetivo verificar a influência de determinantes sociais de saúde na distribuição dos indivíduos entre os grupos de trajetória extraídos por meio de análise de trajetórias baseada em grupos.

Por fim, mas não menos importante, nos deslocamos ao México. Para este artigo Highways to Ageing - Linking life course SEP to multivariate trajectories of health outcomes in older adults, foi utilizada a base de dados "Mexican Health and Aging Study", estudo longitudinal de base populacional que acompanha indivíduos com 50 anos ou mais desde 2001. Foi desenvolvida análise de multitrajetórias para agrupamento de indivíduos, considerando a 
interdependência de aspectos relacionados à mobilidade, comorbidades e percepção subjetiva de saúde. Para validação do modelo final de trajetórias, verificou-se o impacto de fatores socioeconômicos provenientes de diferentes fases de vida (infância/ adolescência/ vida adulta), apresentados como resultado de um modelo de classes latentes. A vinculação de dois modelos probabilísticos revela interessantes aspectos relacionados à heterogeneidade do envelhecer e a influência das oportunidades ao longo da vida na qualidade do envelhecer. 


\section{OBJETIVOS}

4.1 Objetivos gerais

$>$ Verificar a existência de múltiplas Trajetórias de Funcionalidade em amostra de idosos;

> Comparar trajetórias de funcionalidade de pessoas idosas em duas coortes distintas de idosos;

$>$ Analisar o efeito de exposições a determinantes sociais de saúde ao longo da vida em trajetórias de funcionalidade de idosos. 


\section{MÉTODOS}

\subsection{TIPO DE ESTUDO}

Na coletânea de artigos que compõe a presente tese, todos os estudo são classificados como estudos observacionais do tipo coorte.

\subsection{AMOSTRA, LOCAL E PERÍODO DA PESQUISA}

A coletânea de artigos que compõem a tese investiga os processos de envelhecimento populacional com base em amostras do Brasil, Chile e México. As duas primeiras amostras fazem parte do estudo multicêntrico intitulado Saúde Bem-Estar e Envelhecimento ${ }^{77}$, a terceira amostra do Mexican Health Aging Study (MHAS). Os anos de acompanhamento foram 2000, 2006, 2010 e 2016 para o Estudo SABE Brasil; 2000, 2005 e 2010 para o Estudo SABE Chile e 2001, 2003, 2012 e 2015 para o MHAS. Detalhes sobre os estudos e processos de amostragem serão abordados diretamente nos respectivos artigos.

\subsection{VARIÁVEIS DOS ESTUDOS}

a. Variáveis de Desfecho

As variáveis de desfecho foram baseadas primariamente em medidas funcionais, avaliadas por uma combinação de atividades básicas e instrumentais da vida diária ${ }^{19,78}$ e atividades relacionadas à mobilidade.

\section{Funcionalidade para ABVD}

A avaliação de funcionalidade de atividades básicas de vida diária foi feita por meio do desempenho autorreferido. Ao todo, seis atividades foram consideradas (alimentar-se, banhar-se, vestir-se, continência e transferir-se da cama para cadeira) a partir da pergunta: "O senhor/ $A$ senhora tem dificuldade para (atividade em questão)?”. Para cada atividade o indivíduo foi classificado com ou sem dificuldade autorreferida.

2. Funcionalidade para AIVD 
Como atividades instrumentais de vida diária foram consideradas as respostas para as seguintes questões: preparar uma refeição quente, cuidar do próprio dinheiro, fazer compras, telefonar, realizar tarefas domésticas leves, tomar remédios). Os indivíduos foram classificados com ou sem dificuldade a partir da resposta fornecida para a questão: "O senhor/ A senhora tem dificuldade para (atividade em questão)?”. O qualificador utilizado para avaliação da condição funcional dos idosos foi a dificuldade autorreferida para desempenho de cada AIVD.

3. Atividades de mobilidade

Foram selecionadas sete atividades referentes à mobilidade, sendo elas: caminhar vários quarteirões, caminhar um quarteirão, subir escadas, agachar-se, empurrar objetos / móveis grandes, transportar um objeto com mais de cinco quilos, pegando uma moeda da mesa.

b. Variáveis Independentes

- Sociodemográficas e Econômicas - avaliadas no baseline

Sexo (feminino e masculino); Idade; Cor da pele; Escolaridade; Suficiência financeira, avaliada por meio de uma pergunta sobre a suficiência financeira percebida, ou seja, se a pessoa idosa considerava ter dinheiro suficiente para as despesas mensais.

- Situação de saúde

Autopercepção de saúde foi avaliada por meio da pergunta: "Como o senhor/ a senhora percebe a sua saúde atualmente?".

Número de doenças crônicas autorreferidas (DCA): Foram consideradas de maneira paramétrica: a. hipertensão arterial, b. diabetes, c. cardiopatias, d. histórico de acidente vascular cerebral, e. doença pulmonar obstrutiva crônica, f. artropatias.

Sintomas depressivos foram avaliados por meio do teste de rastreamento GDS- $15^{79}$.

\subsection{ANÁLISE ESTATÍSTICA}

Duas abordagens distintas foram aplicadas para análise de dados dos artigos finais. 
As trajetórias funcionais identificadas no primeiro artigo foram por agrupamento ex-ante, utilizando uma abordagem determinística de acordo com a classificação proposta Fuentes-García et al. ${ }^{60}$. A utilização de modelos determinísticos é de mais fácil compreensão e reprodutibilidade, uma vez que este delineamento tem como base a formação de grupos de indivíduos que seguem trajetória similar, baseados em modelos conceituais definidos a priori. Modelos determinísticos não são definidos como tal em publicações, simplesmente descreve-se detalhadamente o método de agrupamento pelo qual obtém-se as trajetórias finais.

Modelos determinísticos são amplamente utilizados em estudos transversais que avaliam funcionalidade de idosos. Como exemplo, podemos citar modelos que avaliam fatores associados à dificuldade em desempenhar atividades de vida diária ${ }^{80,81}$, baseados na soma de dificuldades autorrelatadas para desempenho funcional. Fuentes-García e colaboradores ${ }^{82}$, em contrapartida, desenvolveram um modelo para classificar idosos chilenos em três níveis de limitação funcional (sem comprometimento funcional, comprometimento médio e severo).

A segunda abordagem considerada na análise de dados dos artigos 2 e 3 foi a análise probabilística. Neste caso, a partir dos dados de seguimento, extrai-se grupos latentes, indicando trajetórias distintas da evolução do desfecho de interesse, conhecidos como modelos finitos mistos (Finite Mixture Models) para análise de dados longitudinais ${ }^{83}$. Estes modelos não apresentam direcionamentos conceituais a priori, mas por meio direcionamento estatístico, acabam por identificar clusters de indivíduos que compartilham evolução similar ao longo do tempo, a exemplo dos modelos de trajetória baseada em grupos (MTBG), do inglês "Group-Based Trajectory Model".

Após a definição/extração das trajetórias de funcionalidade de cada estudo, modelos de regressão logística e regressão multinomial não ajustados e ajustados foram utilizados para avaliar a associação dos fatores socioeconômicos com as trajetórias funcionais finais, controlados os modelos finais por covariáveis proximais, como características de saúde avaliadas no baseline.

A análise estatística utilizou o Stata versão 15.1 (StataCorp, College Station, TX, 2019). Gráficos de trajetória e gráficos de floresta foram feitos usando o pacote ggplot2, do R, versão 3.5.2. 
Mais detalhes sobre os métodos utilizados e o passo-a-passo adotado para análise dos dados serão apresentados nos artigos que compreendem as partes de Resultados e Discussão da presente tese. 


\subsection{CONSIDERAÇÕES ÉTICAS}

O presente estudo envolve a descrição e análise de dados secundários: de amostra de idosos participantes de inquéritos populacionais de saúde e aspectos de vida de idosos. As bases de dados, quando não anonimizadas já na origem, foram anonimizadas antes do início de cada pesquisa, evitando assim a identificação dos participantes do estudo.

O Estudo SABE - Brasil foi aprovado pelo Comitê de Ética em Pesquisa do Conselho Nacional de Saúde, no ano de 1999. As seguintes ondas foram aprovadas pelo Comitê de Ética em Pesquisa da Faculdade de Saúde Pública da Universidade de São Paulo (COEP/FSP) (Anexo I). De modo similar o Estudo SABE - Chile, contou com aprovação do Comité de Ética del Instituto de Nutrición y Tecnología de los Alimentos de la Universidad de Chile.

O Mexican Health and Aging Study foi aprovado pelos Comitês de Ética da Universidade do Texas Medical. Filial nos Estados Unidos, o Instituto Nacional de Estadística e Geografia (INEGI) e o Instituto Nacional de Saúde Pública (INSP) no México. Os arquivos e documentação de dados são públicos e estão disponíveis em www.mhasweb.org. 


\title{
6. RESULTADOS E DISCUSSÃO
}

\section{Artigo 1: Cumulative Inequalities: is age a leveler? The case of functional trajectories of older adults in two middle-income countries}

\author{
Autores: Etienne Duim, Alejandra Fuentes-García, Cecília Albala, Yeda Aparecida de Oliveira Duarte, José \\ Leopoldo Ferreira Antunes.
}

\begin{abstract}
Background: Functional trajectories offer a broad view of older individual's health condition and involve social inequalities as a predictor. Objective: To determine functional trajectories and compare the impact of education level on later life disadvantaged functional trajectories of older adults in Brazil and Chile. Method: A cross-country study was carried out using data from the 2000, 2005 and 2010 Health, Aging and Well Being Surveys (SABE Study) in Brazil $(n=685)$ and Chile $(n=285)$. Individuals aged $\geq 60$ years were clustered using a deterministic approach based on their ability to perform activities of daily living and on mobility during the study period. Logistic regression models were fitted for trajectory groups. We assessed the marginal probability of belonging to the vulnerable aging trajectory according to age and educational level. Results: Older adults who had less formal education (0-3 years) were 2.7 times more likely to have worse trajectories than individuals with $\geq 8$ years of education. There was difference between countries, with Brazilian older adults presenting the higher the probability of belonging to the disadvantageous trajectories in comparison to Chilean individuals (Odds Ratio 6.1, 95\% Confidence Interval (CI) 3.55;10.49). Conclusion: Inequality of access to education proved a predictor of disadvantaged trajectory in older adults living in the middle-income countries studied, with a substantial difference between older adults from Chile and Brazil.
\end{abstract}

Keywords: Ageing; Health trajectories; Activities of daily living; Socioeconomic status; Social determinants of health, life course perspective 


\section{Background}

According to the World Population Aging Report (2015), Latin America and the Caribbean accounted for $7.9 \%$ of older adults in the world and will be the region with the greatest growth in this population group over the coming decades $(2015-2030)^{1}$. Brazil and Chile are part of this trend, with $14.3 \%$ and $15.8 \%$ of their populations aged 60 and over, respectively ${ }^{2,3}$. Aged populations are associated with higher rates of disability ${ }^{4}$. However, research in high-income countries suggests that aging processes are modifiable and people are living longer with less severe disability ${ }^{5}$.

There is an increasing interest in evaluating the determinants of older people's health, given that the ability to perform activities allows older individuals to remain autonomous and live in the community for longer ${ }^{6-9}$. The influence of the environment and social determinants on health can be better understood from a life-course approach. This idea offers a more comprehensive perspective that includes the socio-historical dynamics which shape the conditions and experiences of people's lives over time.

From a life-course perspective, Ferraro et al. conclude that the health condition of older adults reflects the accumulation of inequalities during the life course ${ }^{10,11}$. Among the potential social determinants of health, formal education plays an important role in aging ${ }^{12}$, potentially promoting long-term effects, impacting people lives, social organizations and health status over time ${ }^{13}$.

In the background, one must consider the socio-political differences that guided the conceptions and transitions of the health system models in both countries. While Chile, throughout history, has solidified a health system without universal coverage, centered on the practice of 
liberal medicine, in which the patient chooses the professional who will attend him and makes the payment in a particular way. At the end of the 1970s, the Chilean health system was regionalized, the primary attention was privatized, funded by the State and employees, with the possibility of choosing between the state or private health plans, and finally presenting an access stratified by income $^{16}$.

In Brazil, at the beginning of the 1920s, there were two projects for the care of the population's health: one focused on aspects of a collective nature and the other on individual care, aimed at employed people. Public health was among the development plans in Brazil. However, territorial extension and disagreement with centralized or decentralized power made it difficult to develop a solid project for the entire country. During the military dictatorship, the idea of unifying public health and medical assistance, guaranteed by the state, was strengthened ${ }^{16}$. The Brazilian Health System has existed so far, but coexisting with a supplementary system and private health services at all levels ${ }^{17}$. These are some of seminal differences among these countries that have impacted the dynamics of social inequalities in older age.

The historical path of social policies related to determinants of health, such as education, should be considered in the analysis of older people's health. Although geographically close, Brazil and Chile exhibit differences in educational history. In spite of national policies that guarantee basic education for citizens (since 1920 in Chile ${ }^{14}$ and 1934 in Brazil ${ }^{15}$ ), pronounced differences have existed among older adults, especially between individuals who achieved literacy and high levels of education versus those with lack of educational opportunity.

Two theories seek to explain these impacts on aging, namely, the Cumulative Advantage Disadvantage (CA|DT) and Age-As-Leveler (AAL) theories. 
According to Ferraro et al. ${ }^{11}$, social inequalities may determine individuals' disadvantages or advantages during the life course, culminating in worse or better conditions in the aging process. Due to the gap in opportunities, individuals with lower education levels are more exposed to poverty, tend to make worse decisions throughout their lives, might make unsafe health decisions, and also have decreased access to health services ${ }^{18}$. According to the AAL theory ${ }^{19}$, as people get older the inequalities in their health conditions decrease despite education or economic status, supported by the hypothesis that adaptation during the life course promotes the compression of health inequalities, biased by mortality selection. The present study seeks to compare the impact of education level on the functional trajectories of older people from two middle-income countries, over an 11-year follow-up. Two questions should be answered: 1) Is educational level a risk factor in determining disadvantaged functional trajectories, thereby supporting CA|DT or does age acts to level the impact of education on later functional trajectories? 2) Are there differences in the functioning path of older adults from Brazil and Chile by educational level?

\section{Method}

Study Data

Data for the present study was drawn from the Health, Well-being and Aging Survey (SABE Study). This survey was designed by the Pan-American Health Organization to evaluate health and life conditions (at baseline) of the older population in seven countries of Latin America and the Caribbean ${ }^{20}$. The current study used information on individuals from Brazil (Sao Paulo) and Chile (Santiago), the only two countries that followed-up the baseline sample for 11 years, consisting of three waves (2000, 2005 and 2010). Comprehensive home-based assessments were 
completed at baseline and subsequently at 5-year intervals in a sample of men and women aged 60 years and over.

\section{Study Sample}

This paper is based on a subsample of Chilean and Brazilian older people, with two inclusion criteria:1. having participated in all three waves of the SABE Study (survivors); and 2. having answered the questions about functional status.

\section{Assessment of Functioning}

The outcome was based in functioning measures, assessed by a combination of selfreported performance of basic and instrumental activities of daily living ${ }^{21}$ and Lawton ${ }^{22}$ and activities related with mobility, controlled by cognitive status. This includes six basic activities of daily living (ADL) (bathing, dressing, toileting, transferring (moving in or out of chair or bed), continence, and feeding), five instrumental activities (IADL) (preparing a hot meal, handling one's own money, doing the shopping, telephoning, doing light housework, taking medicines), and seven mobility activities (walking several blocks, walking one block, climbing stairs, squatting, pushing large objects/furniture, transporting an object weighing more than five kilos, picking up a coin from the table).

Cognitive status was measured using a screening test for dementia validated in Chile ${ }^{23}$, consisting of a combination of the Mini-Mental State Examination (MMSE) and the Pfeffer Functional Activities Questionnaire (PFAQ).

Functional limitation was classified by level and domain, according to the type of activity of daily living and cognitive status as described below. 
The three levels of the limitation variable were:

- Not limited: limitation $\leq 2$ Mobility activities, or 1 IADL. Without limitation in ADL.

- Mild/moderate limitation: limitation $\geq 3$ Mobility activities or $\geq 2$ IADL with limitation. Without limitation in ADL, or MMSE $<13$ and PFAQ $>11$.

- Severe limitation: limitation $\geq 1$ ADL or MMSE $<13$ and PFAQ $<11$.

The cut offs variables were validated in contrast to observed measurements such as dynamometer high strength; timed up and go; chair rise performance; and mortality. This cut off correctly classified around $70 \%$ of the sample ${ }^{24}$.

Each activity was rated according to the classification of Presence or Absence of limitation, by wave. The functional trajectory of older adults from Chile and Brazil emerged from the combination of all three waves of classification.

Assessment of covariables

Sex and age (60-64, 65-69, 70-74 or $\geq 75$ years), as recorded at the baseline, were assessed as covariables.

Educational status was assessed by two variables: 1 . level of education, based on completed years of formal education (low education: 0-3 years of formal education, middle education: 4-7, and high education: $\geq 8$ years). 2. Having attended school, information based on the question: "Did you attend school at some point in your life?", valid responses were Yes or No. Both variables were self-reported. 
Perceived income sufficiency was evaluated based on the question: "Do you believe that the money you receive monthly is sufficient for your expenses?" (Yes; No).

Self-rated Health was classified as: 1. very good or good, 2. regular, and 3. poor or very poor. Five non-communicable diseases (diabetes, arterial hypertension, chronic obstructive pulmonary disease, cardiovascular disease and arthrosis) were assessed according to the answer to a direct question: "Have you ever been told by a doctor or a nurse that you suffer from any of the following diseases". Depressive symptoms were assessed by the Geriatric Depression Scale -short version ${ }^{25}$ ( $\geq 5$ points on the scale defined depressive symptoms).

\section{Statistical Analysis}

We modeled the wave-to-wave functional status. The functional trajectories were identified by cluster analysis, using a deterministic approach according to the proposed classification ${ }^{24}$. The final trajectory groups were derived from the sum of individuals possibilities, and older adults following a similar path were clustered in the same trajectory group (Groups A to E).

We proposed a second classification to facilitate data analysis. Individuals were classified into two groups, those with Highly Functional Trajectories (individuals from Groups A and B) and individuals with Disadvantaged Trajectories (Groups C, D and E). All statistical analyses were carried out using this final classification.

Unadjusted and adjusted logistic regression models were fitted to test the association of education with Disadvantaged Functional Trajectories.

The marginal probability of belonging to the worst functional trajectories was estimated according to education and age, and stratified by country. These post-estimation analyses were performed based on the estimated OR of adjusted logistic models (final model). Thus, the marginal 
effect is considered a statistic based on a fitted model, where some variables are fixed. Controlled by the other covariables in the full model, the impact of these independent variables on the outcome can be predicted and projected on a plot. In this study, values based on education and age were fixed to estimate the probability of belonging to the Disadvantaged Functional Trajectory group, with estimations controlled by other covariables present in the full models of both countries ${ }^{26}$.

All analyses were performed using Stata version 15.1, 2017 (StataCorp, College Station, TX, USA).

\section{Results}

The sociodemographic characteristics and health condition (at baseline) of individuals from both longitudinal studies are given in Table 1.

The baseline characteristics of the 234 men and 451 women from Sao Paulo, Brazil, along with the 94 and 190 from Santiago, Chile, in the final sample of individuals that started the study in 2000 and survived until 2010, are given in Table 1. Gender distribution was similar in both samples, although $46 \%$ of Sao Paulo participants were aged 60-64 years in 2000, while the Santiago participants sample was more equally distributed across the different age groups. Differences in educational level between these South American countries were observed, where almost half of the Brazilian older adults surveyed had a low educational level versus only $25.6 \%$ of the Chilean individuals.

A major proportion of older adults living in Sao Paulo had better self-rated health $(51.3 \%)$ than those living in Chile (42.2\%). On the other hand, there was a higher proportion of older adults with no functional limitation at baseline in Chile (67.0\%) than in Brazil (58.3\%). However, the Sao Paulo sample had fewer non-communicable diseases and lower prevalence of falls in the past 
year at baseline compared to the older adults from Santiago. The prevalence of depressive symptoms was similar in both samples (Table 1).

Table 1. Definition of trajectoy groups and description of final final trajectories groups of the study. Brazil-Chile, 2000-2010.

\begin{tabular}{lllrr}
\hline Group & $\begin{array}{l}\text { Trajectory of } \\
\text { Functioning* }\end{array}$ & Characteristic & Brazil & Chile \\
\hline Group A & No-No-No & Active ageing & - & 25.3 \\
Group B & No-No-Yes & Slow limitation process & 23.1 & 33.8 \\
Group C & No-Yes-Yes & Fast limitation process & 35.3 & 8.1 \\
Group D & Yes-status change & Atypical Process & 7.5 & 16.3 \\
Group E & Yes-Yes-Yes & Vulnerable ageing & 34.1 & 16.5 \\
Final Groups & & & & \\
Functional trajectory & & Groups A and B & 23.1 & 59.1 \\
Vulnerable Trajectory & & Groups C, D and E & 76.9 & 40.9 \\
\hline
\end{tabular}

*Yes= with limitation, $\mathrm{No}_{\mathrm{O}}$ without limitation.

The results from deterministic functional trajectories are presented in table 2 . There were five trajectories groups. Groups A and B clustered individuals with the most advantageous functional paths, presenting no limitations in all waves (Active Aging) or with some signals of limitation in the last wave (Compressed Limitation Process), respectively. Both groups corresponded to $23.1 \%$ of the Sao Paulo sample (containing Group B individuals only) and 59.1\% of the Santiago sample.

Individuals assigned to Group $\mathrm{C}$ had no limitation in 2000 but reported limitation in the two subsequent periods (Rapid Limitation Process group). Individuals from Group D reported limitation in all 3 survey periods (Vulnerable Aging group). Group E combined individuals with limitation at baseline and changes of the limitation status for the other 2 periods. The group was called Atypical Limitation Process. 
The majority of individuals followed for 11 years in Brazil were classified into the Disadvantaged Trajectory group (76.9\%) (Table 2).

Table 2. Description (\%) of sociodemographic and economic characteristics and health status of older adults from Sao Paulo and Santiago. Brazil - Chile, 2000.

\begin{tabular}{|c|c|c|}
\hline & Sao Paulo & Santiago \\
\hline \multicolumn{3}{|l|}{ Gender } \\
\hline Male & 36.9 & 32.6 \\
\hline Female & 63.1 & 67.4 \\
\hline $\begin{array}{l}\text { Age in years - mean } \\
\text { (SD) }\end{array}$ & $66.8(0.33)$ & $68.7(6.0)$ \\
\hline \multicolumn{3}{|l|}{ Age group } \\
\hline $60-64$ years & 46.0 & 28.1 \\
\hline 65-69 years & 24.7 & 30.5 \\
\hline $70-74$ years & 19.0 & 23.5 \\
\hline$\geq 75$ years & 10.3 & 17.9 \\
\hline \multicolumn{3}{|l|}{$\begin{array}{l}\text { Years of formal } \\
\text { education }\end{array}$} \\
\hline $0-3$ years & 47.7 & 25.6 \\
\hline 4-7 years & 35.3 & 40.7 \\
\hline$\geq 8$ years & 17.0 & 33.7 \\
\hline \multicolumn{3}{|l|}{ Educational Status } \\
\hline Attended school & 82.9 & 86.3 \\
\hline Never attended school & 17.1 & 13.7 \\
\hline \multicolumn{3}{|l|}{$\begin{array}{l}\text { Perceived income } \\
\text { sufficiency }\end{array}$} \\
\hline Yes & 32.6 & 61.9 \\
\hline No & 67.4 & 38.1 \\
\hline \multicolumn{3}{|l|}{$\begin{array}{l}\text { Self-rated Health } \\
\text { Excellent/Very }\end{array}$} \\
\hline Good/Good & 51.3 & 42.2 \\
\hline Regular/Poor & 48.7 & 57.8 \\
\hline \multicolumn{3}{|c|}{ Number of non-communicable diseases } \\
\hline 0 & 33.9 & - \\
\hline 1 & 33.0 & 1.9 \\
\hline$\geq 2$ & 33.1 & 98.1 \\
\hline \multicolumn{3}{|l|}{ Depressive symptoms } \\
\hline No & 78.2 & 70.1 \\
\hline Yes & 21.8 & 29.9 \\
\hline
\end{tabular}


The Figure 1 shows that the greater the degree of educational deprivation the smaller the proportion of individuals following better functional trajectories in older ages. This gradient is more evident in Brazilian cohort, but still in Chilean individuals, we note a higher proportion of individuals with low education among groups $\mathrm{D}$ and $\mathrm{E}$.

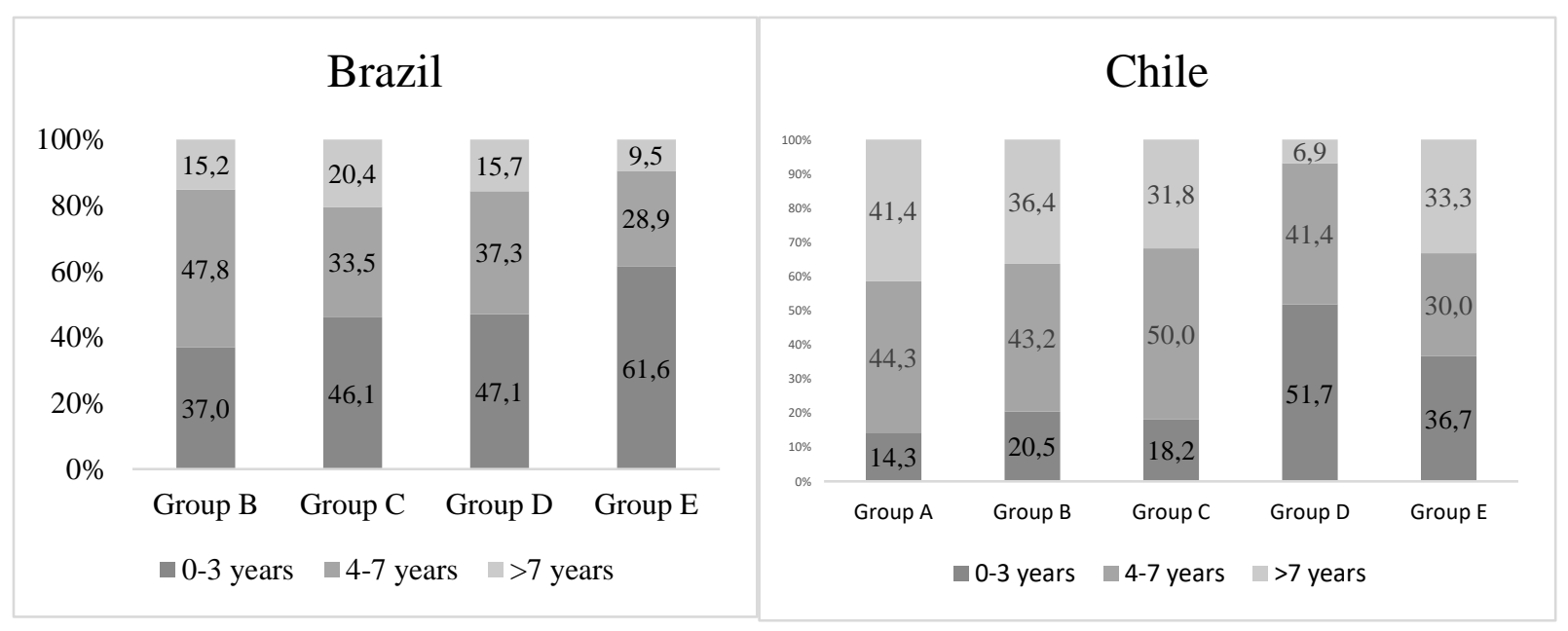

Figure 1. Educational profile according to trajectory group of Brazilian and Chilean sample of older adults. Brazil - Chile, 2000-2010.

Table 3 shows the unadjusted associations between demographic characteristics and health conditions at baseline and functional disadvantaged trajectories. Gender differences in functional trajectories over time were not observed (OR 0.81; IC95\% 0.54;1.20). As age increased, the likelihood of belonging to trajectories with more limitation also rose, affecting more individuals aged $\geq 80$ years in relation those aged $60-64$ years $(80+$ OR 4.21 , IC95\%1.74;10.18).

Older adults who had less formal education (0-3 years) were 2.7 times more likely to have worse trajectories than individuals with $\geq 8$ years of education. Perceived income sufficiency was not associated with functional trajectory. 
Self-rated health and presenting depressive symptoms at baseline were factors for belonging to the worst functional trajectories.

Individuals from Sao Paulo were 3.8times more likely to have disadvantageous trajectories in relation to their counterparts from Santiago. (Table 3). 
Table 3. Unadjusted model for disadvantageous functional trajectories of Brazilian and Chilean older adults. Brazil-Chile, 20002010 .

\begin{tabular}{|c|c|c|}
\hline & \multicolumn{2}{|c|}{ Unadjusted model } \\
\hline & OR & IC95\% \\
\hline \multicolumn{3}{|l|}{ Gender } \\
\hline Male & 1.00 & \\
\hline Female & 0.98 & $0.75 ; 1.30$ \\
\hline \multicolumn{3}{|l|}{ Age group } \\
\hline $60-64$ & 1.00 & \\
\hline $65-69$ & 0.92 & $0.65 ; 1.30$ \\
\hline $70-74$ & 1.35 & $0.94 ; 1.94$ \\
\hline $75-79$ & 2.79 & $1.80 ; 4.31$ \\
\hline 80 years and over & 5.12 & $2.45 ; 10.68$ \\
\hline \multicolumn{3}{|l|}{ Educational level } \\
\hline $0-3$ years & 2.67 & $1.86 ; 3.84$ \\
\hline 4-7 years & 1.12 & $0.79 ; 1.60$ \\
\hline 8 years and over & 1.00 & \\
\hline \multicolumn{3}{|c|}{ Perception of income sufficiency } \\
\hline Yes & 1.00 & \\
\hline No & 1.26 & $0.97 ; 1.65$ \\
\hline \multicolumn{3}{|l|}{ Self-rated Health } \\
\hline Excellent/very good/Good & 1.00 & \\
\hline Regular/Poor & 2.42 & $1.85 ; 3.17$ \\
\hline \multicolumn{3}{|c|}{ Number of non-communicable diseases } \\
\hline None & 1.00 & \\
\hline One & 1.33 & $0.90 ; 1.98$ \\
\hline Two or more & 0.84 & $(0.61 ; 1.17)$ \\
\hline \multicolumn{3}{|l|}{ Depressive symptoms } \\
\hline No & 1.00 & \\
\hline Yes & 1.82 & $1.23 ; 2.68$ \\
\hline \multicolumn{3}{|l|}{ Study site } \\
\hline Santiago - Chile & 1.00 & \\
\hline Sao Paulo - Brazil & 3.75 & $2.80 ; 5.00$ \\
\hline
\end{tabular}

There was no difference between attending 4-7 years and more than seven years of formal education. However, the odds of disadvantageous functional trajectories were $93 \%$ and $70 \%$ higher 
for individuals with lower levels of formal education, in the model with only Country as covariate and in the full adjusted model, respectively.

When adjusted for other covariates, we found an increment in the estimated odds for disadvantageous trajectories in the Brazilian sample in comparison to the Chilean sample, but the relation remained stable for education (Table 4).

Table 4. The impact of education in functional trajectories of Brazilian and Chilean older adults accessed by adjusted logistic regression model. BrazilChile, 2000-2010.

\begin{tabular}{lrr}
\hline & OR & IC95\% \\
\hline $\begin{array}{l}\text { Mutual adjustment } \\
\text { Educational level } \\
\text { 0-3 years }\end{array}$ & & \\
4-7 years & 1.93 & $1.32 ; 2.83$ \\
$\quad$ years and over & 0.93 & $0.64 ; 1.35$ \\
Study site & 1.00 & \\
$\quad$ Santiago - Chile & & \\
Sao Paulo - Brazil & 1.00 & \\
Fully Adjusted** & 3.25 & $2.40 ; 4.41$ \\
Educational level & & \\
0-3 years & & \\
4-7 years & & \\
8 years and over & 1.70 & $(1.02 ; 2.84)$ \\
Study site & 0.75 & $(0.45 ; 1.16)$ \\
Chile & 1.00 & \\
Brazil & & \\
\hline
\end{tabular}

**Adjusted by: sex, age, perception of income sufficiency, Self-rated health, number of non-communicable diseases and depressive symptoms.

The marginal analysis' graphs are depicted in Figure 2. The y-axis represents the probability of worst functional trajectory, whereas the x-axis displays age groups at baseline. Lastly, each line represents a different educational level. Although a consistent influence of age is evident, 
individuals who had $\leq 3$ years of formal education were more likely to have a trajectory with functional impairment.

The results highlighted different situations in Brazil and Chile. For older adults living in Sao Paulo, age was a factor increasing the probability of decreased functional trajectory. Additionally, the explanatory power of educational level seemed to dilute, collapsing the probabilities of different educational groups into one at an age of 80 years or over. For example, an older adult aged 62 years (age group: 60-64) at baseline with 7 years of formal education had less than $60 \%$ probability of having a worst functional trajectory (follow the red line of the graph). Another individual of the same age, but reporting less than 3 years of formal education (Blue line), had a $75 \%$ probability of a worst trajectory. Considering an individual aged 80 years or older, both examples (with higher or lower educational level) had the same probability of having a disadvantaged trajectory $(\operatorname{Pr} \approx 0.99)$ (Figure $2 \mathrm{~A})$.

In the Santiago sample (Figure 2B), probabilities of trajectory were associated with educational level, showing a gradual increase according to age at baseline, suggesting that limitation processes affect individuals differently depending on educational level and age (Figures 2A). For instance, taking the same age example, a 62-year-old with 8 years of formal education had a $<20 \%$ probability of having a disadvantaged trajectory. By contrast, another older adult, with the same age, but a lower educational level, had a $38 \%$ probability to be part of the disadvantaged trajectory. In the case of 80-year-olds, the differences in the likelihood of an unsatisfactory trajectory increased while maintaining the impact of educational level (older people with lower educational level had a higher likelihood of worse trajectory, regardless of age).

In both cases, the models were controlled by sex, self-rated health, and the number of noncommunicable diseases. 

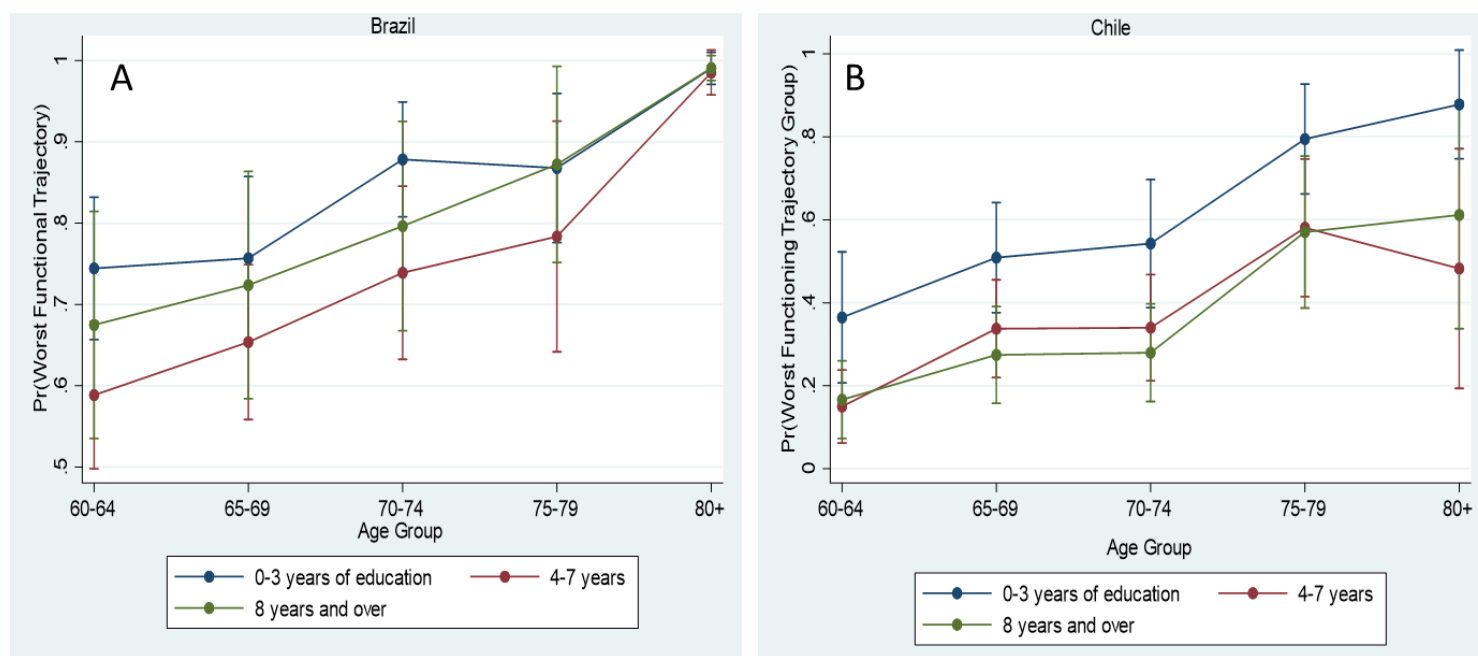

Figure 2. Probability of worst functional trajectory according to educational level and age group in Brazilian (A) and Chilean (B) older adults, 2000-2010.

\section{Discussion}

This study emphasized that the aging conditions of the Brazilian and Chilean people differed from a life-course perspective. This difference is made clear by the fact that $40.9 \%$ of older adults from Chile aged in worse conditions of physical function versus almost double the proportion (76.9\%) in the Brazilian sample. Results also reinforced that education can be regarded as an important factor promoting better trajectories of aging. These results reflect overall worse functional trajectories of older people living in the largest city in Brazil compared with their Chilean counterparts.

The strong impact of the local of residence influences which perspective of aging the individual tends to experience. It reflects the social fragilities affecting these two South American countries differently ${ }^{16}$. Even though the concentration of income occurs in both countries, continued social projects still contribute to health indicators in Chile today ${ }^{16,27}$. Whereas in Brazil, 
social projects end up with each election process. It has been used as tools of power. Since social policies are structures of medium and long-term change, their inconsistency can have consequences for future generations or for the future of generations that experience such changes $^{28,29}$. The price paid for discontinuity can be seen in the aging conditions of elder population.

Access to education was (and still is) a mechanism of social stratification in Brazil. Although the Brazilian Constitution of 1934 enshrined primary education (first four years of education) as compulsory, educational provision did not reflect the legislation. Today's Brazilian older adults were not fully embraced by this type of policy, a fact evidenced by higher rates of illiteracy ${ }^{15,30}$. It can be noted that Chile, since the 1920 s, ensures the right to education (four years - basic education) as a citizen's initiative, thus resulting in a higher level of formal education of the current older population compared to the same generation in Brazil ${ }^{14}$. Nevertheless, four years of education is no guarantee of quality and literacy ${ }^{12,15}$ nor of a better functional trajectory during aging.

The present results reinforce the idea of education as a social determinant of health ${ }^{31}$, where this determinant affected functional trajectory after the age of 60 , corroborating results of previous studies $8,32,33$. The strength of the present study findings hinges on the differences according to the impact of education in the aging process, comparing two middle-income countries. In Chile, results sustained the idea of the cumulative effect of education on late-life trajectory, where formal education shaped the probability of a worse or better functional scenario in old age ${ }^{10,34,35}$. These differences went beyond the age effect, reflecting a social stratification of functional trajectories ${ }^{36}$. On the other hand, considering the Brazilian population, age was more important than level of education in relation to a functional limitation course. The convergence of 
the probability of having disadvantaged functional trajectories with age, independently of education, is sustained by the Age-As-Leveler theory ${ }^{19}$. As mentioned by Dupre ${ }^{37}$, this pattern is first attributed to mortality, where more robust individuals remain alive. Nonetheless, despite the mortality bias, these older adults from Brazil seemed to be more impaired, even at baseline. Therefore, several factors might explain the reported results, such as resilience - a personal tool developed through the life course that has a protective effect even in face of growing disabilities 38. Unfortunately, this proposition could not be tested empirically in this study.

While the number of chronic conditions had no direct impact on functional trajectories in both countries, multimorbidity may affect physical activity as well as self-rated health and quality of life ${ }^{9,39,40}$. From a longitudinal perspective, these elements can promote worse functional outcomes, as seen in other studies of disability trajectories ${ }^{41,42}$.

Strategies related to early detection of functional deterioration, adequate follow-up, and treatment to monitor non-communicable diseases could promote better aging trajectories. As a factor of cumulative disadvantages during the life course, health policies focusing on older adults with low educational levels should be developed, in addition to educational opportunities for new generations of older adults. Action is needed more than research regarding this topic.

The strengths of the study include the analysis of 11 years of data from a multicenter representative longitudinal study exploring the physical function of older adults. Thus, the study results provide a broad perspective of health in aging, based on changes in functioning throughout the aging life course, beyond a perspective based on morbidity at a given point in time.

A potential limitation concerns the fact that only complete data were analyzed for the outcome of interest. Attrition due to death or institutionalization could be strongly related to the 
outcome and main independent variable of the study. However, the study objective was to focus on the characteristics of aging in a survivor sample. Sensitivity analysis showed that individuals who lost follow-up were more disabled, reported a worse perception of health and also had lower educational levels for both countries, as expected by survivors' bias ${ }^{43,44}$.

In summary, differences in government support to social policies, partially explained by education in this paper, are important factors influencing functioning in the aging course of a population. Comparatively, a greater proportion of the older adults living in Sao Paulo (Brazil) had lower individuals in functional trajectories than those living in Santiago (Chile). This study raises evidence to support the two life-course theories (cumulative advantage-disadvantage and age as a leveler) suggesting that the local sociocultural contexts are important to determine the impact of socioeconomic inequalities over age in later life. These results bear relevance in the discussion of social inequalities from a life-course perspective. Our findings lend credence to the idea that socioeconomic inequalities and the continuity of social policies may determine the path of aging. Indeed, Chileans with less than 3 years of education had worse functional trajectories than more educated individuals, a gap which persisted until later old age.

\section{References}

1. United Nations, Department of Economic and Social Affatis Population Division. World Population Ageing 2015. New York; 2015.

2. AMUCH. Los adultos mayores en las comunas de Chile: actualidad y proyecciones. Santiago de Chile; 2017.

3. IBGE, Coordenação de População e Indicadores Sociais. Síntese de Indicadores Sociais - 
Uma análise das condições de vida da população brasileira. 2016.

4. World Health Organization. International Health Regulations (2005) and chemical events. Vol. 1, WHO. Geneva; 2015. 33 p.

5. Christensen K, Doblhammer G, Rau R, Vaupel JW. Ageing populations: the challenges ahead. Lancet (London, England). 2009;374(9696):1196-208.

6. Lee J, Cho S-I, Chun H, Jung-Choi K, Kang M, Jang S-N. Life course indices for social determinants of self-rated health trajectory in Korean elderly. Arch Gerontol Geriatr. 2017;70:186-94.

7. Kuh D, Karunananthan S, Bergman H, Cooper R. A life-course approach to healthy ageing: maintaining physical capability. Proc Nutr Soc. 2014;73(2):237-48.

8. Zimmer Z, Martin LG, Nagin DS, Jones BL. Modeling Disability Trajectories and Mortality of the Oldest-Old in China. Demography. 2012;49(1):291-314.

9. MacNeil Vroomen JL, Han L, Monin JK, Lipska KJ, Allore HG. Diabetes, Heart Disease, and Dementia: National Estimates of Functional Disability Trajectories. J Am Geriatr Soc. 2018;66(4):766-72.

10. Ferraro KF, Kelley-Moore JA. Cumulative Disadvantage and Health: Long-Term Consequences of Obesity? Am Sociol Rev. 2003;68(5):707-29.

11. Ferraro KF, Shippee TP. Aging and cumulative inequality: how does inequality get under the skin? Gerontologist. 2009;49(3):333-43.

12. Sisco S, Gross AL, Shih RA, Sachs BC, Glymour MM, Bangen KJ, et al. The Role of Early- 
Life Educational Quality and Literacy in Explaining Racial Disparities in Cognition in Late Life. Journals Gerontol Ser B Psychol Sci Soc Sci. 2015;70(4):557-67.

13. Pakpahan E, Hoffmann R, Kröger H. The long arm of childhood circumstances on health in old age: Evidence from SHARELIFE. Adv Life Course Res. 2017;31:1-10.

14. Illanes MA. En el nombre del pueblo, del estado y de la ciencia. Historia social de la salud publica, Chile 1880 - 1973. Santiago de Chile: Ministerio de Salud. Protege Red de Protección Social, Gobierno de Chile; 2010. 515 p.

15. Flach S de F. Direito à educação e obrigatoriedade escolar no Brasil: entre a previsão legal e a realidade. Rev HISTDBR On-line. 2011;43:285-303.

16. Labra ME. Política e saúde no Chile e no Brasil: contribuições para uma comparação. Cien Saude Colet. 2001;6(2):361-76.

17. Duarte E, Eble LJ, Garcia LP, Duarte E, Eble LJ, Garcia LP. 30 anos do Sistema Único de Saúde. Epidemiol e Serviços Saúde. 2018 ;27(1).

18. Dupre ME. Educational differences in health risks and illness over the life course: a test of cumulative disadvantage theory. Soc Sci Res. 2008;37(4):1253-66.

19. Ferraro KF, Farmer MM. Double jeopardy, aging as leveler, or persistent health inequality? A longitudinal analysis of white and black Americans. J Gerontol B Psychol Sci Soc Sci. 1996; 51(6):S319-28.

20. Albala C, Lebrão ML, León Díaz EM, Ham-Chande R, Hennis AJ, Palloni A, et al. Encuesta Salud, Bienestar y Envejecimiento (SABE): metodología de la encuesta y perfil de la 
población estudiada. Rev Panam Salud Pública. 2005;17(5-6):307-22.

21. Katz S, Ford AB, Moskowitz RW, Jackson BA, Jaffe MW. Studies of Illness in the Aged. The Index of ADL: a standardized meadure of biological and psychosocial function. J Am Med Assoc. 1963;185(12):914-9.

22. Lawton MP, Brody EM. Assessment of older people: self-maintaining and instrumental activities of daily living. Gerontologist. 1969;9(3):179-86.

23. Quirroga P, Albala Brevis C, Klaasen G. Validation of a screening test for age associated cognitive impairment, in Chile. Rev Med Chile. 2004;132:467-78.

24. Fuentes-García A, Sánchez H, Lera L, Cea X, Albala C. Desigualdades socioeconómicas en el proceso de discapacidad en una cohorte de adultos mayores de Santiago de Chile. Gac Sanit. 2013;27(3):226-32.

25. Yesavage JA, Sheikh JI. Geriatric Depression Scale(GDS): recent evidence and development of shorter violence. Clin Gerontol. 1986;5(1-2):165-73.

26. StataCorp. Stata 15 Base Reference Manual. College Station, Tx: Stata Press; 2017. 2997 p.

27. Muñoz CM. La salud en Chile. Una historia de movimientos, organización y participación social . Ediciones UACh; 2019. 1-212 p.

28. Brender A, Drazen A. Consolidation of New Democracy, mass attitudes, and clientelism. Am Econ Rev. 2009;99(2):304-9.

29. Machado JC, Cotta RMM, Soares JB. Reflexões sobre o processo de municipalização das 
políticas de saúde: a questão da descontinuidade político-administrativa. Interface - Comun Saúde, Educ. 2015;19(52):159-70.

30. Goldemberg J. O repensar da educação no Brasil. Estud Avançados. 1993;7(18):65-137.

31. Braveman P, Egerter S, Williams DR. The Social Determinants of Health: Coming of Age. Annu Rev Public Health. 2011;32(1):381-98.

32. Díaz-Venegas C, Wong R. Trajectories of limitations in activities of daily living among older adults in Mexico, 2001-2012. Disabil Health J. 2016;9(3):524-32.

33. Zimmer Z, Bao L, Mayol NL, Chen F, Perez TLL, Duazo PL. Functional limitation trajectories and their determinants among women in the Philippines. Demogr Res. 2017;36:863-92.

34. Dannefer D. Systemic and Reflexive: Foundations of Cumulative Dis/Advantage and LifeCourse Processes. Journals Gerontol Ser B. 2018;

35. Crystal S, Shea D. Cumulative advantage, cumulative disadvantage, and inequality among elderly people. Gerontologist . 1990;30(4):437-43.

36. Xu X, Liang J, Bennett JM, Botoseneanu A, Allore HG. Socioeconomic stratification and multidimensional health trajectories: Evidence of convergence in later old age. Journals Gerontol - Ser B Psychol Sci Soc Sci. 2015;

37. Dupre ME. Educational Differences in Age-Related Patterns of Disease: Reconsidering the Cumulative Disadvantage and Age-As-Leveler Hypotheses*. J Health Soc Behav. 2007;48:1-15. 
38. Phillips SP, Auais M, Belanger E, Alvarado B, Zunzunegui M-V. Life-course social and economic circumstances, gender, and resilience in older adults: The longitudinal International Mobility in Aging Study (IMIAS). SSM - Popul Heal. 2016;2:708-17.

39. Santosa A, Byass P. Diverse Empirical Evidence on Epidemiological Transition in Lowand Middle-Income Countries: Population-Based Findings from INDEPTH Network Data. PLoS One. 2016;11(5):e0155753.

40. Schäfer I, Hansen H, Schön G, Höfels S, Altiner A, Dahlhaus A, et al. The influence of age, gender and socio-economic status on multimorbidity patterns in primary care. first results from the multicare cohort study. BMC Health Serv Res . 2012;12(1):89.

41. Chiu C-J, Wray LA. Physical disability trajectories in older Americans with and without diabetes: the role of age, gender, race or ethnicity, and education. Gerontologist. 2011;51(1):51-63.

42. Chen C-M, Su Y-Y, Mullan J, Huang M-S, Chiu H-C. Trajectories of Disability and Their Relationship with Health Status and Social Service Use. Exp Aging Res. 2015;41(3):24058.

43. Zethof D, Nagelhout GE, de Rooij M, Driezen P, Fong GT, van den Putte B, et al. Attrition analysed in five waves of a longitudinal yearly survey of smokers: findings from the ITC Netherlands survey. Eur J Public Health. 2016;26(4):693-9.

44. Chatfield MD, Brayne CE, Matthews FE. A systematic literature review of attrition between waves in longitudinal studies in the elderly shows a consistent pattern of dropout between differing studies. J Clin Epidemiol. 2005;58(1):13-9. 


\section{Functional Trajectories and Social Determinants of Health of Brazilian Older Adults}

E Duim $^{1,2,3}$, JLF Antunes ${ }^{1}$, A da Silva ${ }^{4}$, YAO Duarte ${ }^{5}$, V Lima Passos ${ }^{2,3}$

${ }^{1}$ Departmento de Epidemiologia, Faculdade de Saúde Pública - Universidade de São Paulo

${ }^{2}$ Department of Methodology and Statistics, FHML - Maastricht University

${ }^{3}$ Care and Public Health Research Institute (CAPHRI) - Maastricht University

${ }^{4}$ Departamento de Saúde Coletiva - Faculdade de Medicina de Jundiaí

${ }^{5}$ Departmento de Enfermagem Médico-Cirúrgica - Escola de Enfermagem - Universidade de São Paulo

BACKGROUND: Maintaining the performance of activities of daily living is one of the aspects of healthy aging. Concomitant with the study of the hierarchy of the difficulties in performing activities of daily living presented by older adults, there is an interest in elucidating which exposures throughout life are associated with worse functional trajectories. We use trajectory models to highlight the plurality of aging standards, with distinct groups of older adults experiencing functional paths with different levels of onset and speed in this study.

OBJECTIVE: To unveil functional trajectories in older Brazilians and to verify whether social determinants of health are associated factors for worse functional aging.

METHOD: 2,142 individuals (+60 years old), participating in the Health Well-Being and Aging Study - Brazil, from the year 2000 cohort and followed up until 2016. Multivariate GroupBased Trajectory Model was used to identify classes of individuals following similar pattern of functional trajectories based on two outcomes simultaneously: basic and instrumental activities of daily living. Multinomial regression models were used to test associations between bivariate trajectories and social determinants of health. Analyzes were adjusted for health characteristics.

RESULTS: Six trajectories were identified, presenting different profiles of stability and declining functionality in the elderly. Multinomial model indicated that women were more likely to belong to groups with worse functional outcomes. Less education and older age were factors that gradually increased the odds of being part of worse trajectories. Black individuals were more likely than withes of belonging to the trajectory with an accelerated process of functional loss (OR 1.60 95\% Confidence Interval 1.14; 2.26).

CONCLUSION: The results presented highlight the heterogeneity of aging and its relationship with social inequities and indicate the need for actions for specific groups of elderly people, aiming at healthy aging as a process to be contemplated throughout life. Being a woman, 
black and experiencing adverse socioeconomic conditions, such as low schooling, throughout life increases the risk of being attributed to worse functional trajectories in old age.

Key-words: Activities of daily living, Limitation of activity, Older adults, Longitudinal study 


\section{Background}

Maintaining the performance in activities of daily living (ADL) is one of the aspects of healthy aging ${ }^{1}$. Basic activities of daily living (BADL) are those related to self-care (e.g. feeding, dressing, bathing). Throughout the life course, they are the first acquired in the developmental process from childhood on, and the last lost at older ages. Further, in the typology of daily activities, there is also a group of tasks in the functional domain that are necessary for engaging in community life (as using transportation, shopping, taking care of one's own money), known as the instrumental activities of daily living (IADL) $)^{2-4}$.

The ability to perform activities of daily living is acquired gradually, with the development of basic followed by the instrumental skills. Functional decline in old age occurs in the reverse order, beginning with the impairment of more complex activities, and followed by the basic ones ${ }^{5}$.

Few studies have evaluated aging trajectories considering this hierarchy of functional loss ${ }^{5}$ or evaluating the inter-relations between basic and instrumental activities ${ }^{6,7}$. The downside of studying ADL groups separately is that it can obscure the variation of their interdependence, giving rise, as a result, to potential misinterpretations of their cross-domains linkages. To date, there is still a lack of longitudinal studies that incorporate multivariate analysis to evaluate the codependence of basic and instrumental activities of daily living, as well as the impact of life course exposures in these intrinsic relations through the aging process. Such state of affairs is at variance with recent reports laying bare the heterogeneity in aging trajectories ${ }^{8-10}$ also from studies focusing on the paths of function in the elderly population.

Age is considered one of the main risk factors associated with loss of functioning in older adults. Functional decline reflects the influence of biological and clinical factors, such as disease, chronic conditions, cognitive decline, nutritional aspects, and falls ${ }^{11-13}$. However, socioeconomic characteristics, especially when takin g the life course stance, are also critical determinants for functional loss in aging populations ${ }^{14-16}$. The current and overwhelming consensus is that conditions/characteristics of life and work, e.g. education, race, sex, income level, social habits, play a major role in the developmental origins of health and disease, also for the older population ${ }^{17,18}$. Taking a life course perspective, Torres and colleagues ${ }^{19}$ showed that social determinants, to which individuals were subjected throughout their lives had a punctual and permanent impact on 
the aging process, being linked to maintenance or loss of functionality in different groups of elderly.

This study aimed to identify and describe functional trajectories of older adults followed by 16 years. We purported to investigated whether there are distinct gradations and paths of BADL and IADL decline, considering not only their individual developments, but also their temporal patterns of co-dependence. The second aim was to explore the link between the socioeconomic exposures during the life course and the identified (bivariate) functional trajectories, with a particular interest in sex, racial and educational inequalities.

\section{Methods}

\section{Study Data}

Data for the present study was drawn from the Health, Well-being, and Aging Survey (SABE Study, for the acronym in Portuguese). This survey was designed by the Pan-American Health Organization to evaluate health and life conditions (at baseline) of the older population in seven countries of Latin America and the Caribbean ${ }^{20}$.

The initial sample was obtained in 2000, using a multi-stage design, which aimed to statistically analyze the urban population of 60 years of age or older $(n=2,143)$. The primary and secondary sampling units were the city's census tracts and the households, respectively. After six years, 1115 individuals were still in the study (second wave). The third wave (2010) included 748 individuals, and, in 2016, 382 individuals from the original sample. Overall, 2,142 individuals answered questions about basic and instrumental ADL and were used for GBTM analysis. However, during the 16 years of follow-up, only $16.6 \%$ provided information on all waves. From the initial sample, $80.4 \%$ dropped out during the whole follow-up (dropout reasons were death, institutionalization, missed contact, and refusals to participate), whereas $3.0 \%$ contributed intermittently.

\section{Study Sample}

Comprehensive home-based assessments were completed at baseline and subsequently at 5 -year intervals in a sample of men and women aged 60 years and over. The inclusion criterion for this study were answering questions about functional status. 


\section{Measures}

\section{Outcomes.}

Two outcomes were considered and assessed by a combination of the self-reported performance in basic and instrumental activities of daily living, according to the Katz ${ }^{3}$ and Lawton ${ }^{4}$ definition. The answers to the questionnaire's items were binary: if the respondent had difficulty to perform any of the six BADL (bathing, dressing, toileting, transferring in or out of chair or bed, continence, and feeding), and five IADL (taking medicines, taking care of money, shopping, using transportation, and using the telephone). Instrumental activities mainly done by women (e.g. preparing a hot meal and doing light housework) were excluded to avoid gender bias ${ }^{21}$. Responses "cannot answer" or "does not perform the activity" were considered missing values. Each dichotomized answer was added to generate a sum score (0-6 for BADL and 0-5 for IADL). This process was repeated for each wave of the cohort.

\section{Independent Variables}

Demographic and Socioeconomic characteristics.

Sex, age (60-69, 70-79, and 80 or more years old), skin color according to Brazilian classification $^{22}$ (white and black or brown/mixed), educational level based on completed years of formal education (none for illiterate individuals, low education or 1-3 years of formal education, elementary school or 4-7 years, and high school or 8 or more years), and self-reported income sufficiency (based on the question: "Considering your monthly expenses, do you have income sufficiency?").

\section{Additional Covariates}

Health Status. Cognitive impairment was evaluated by the Mini-Mental State Evaluation $(\mathrm{MMSE})^{23}$. Individuals were classified as cognitively impaired if their the sum score $>12$ points. Self-rated health was classified as 1. very good or good, 2. regular, poor, or very poor. Five noncommunicable diseases (diabetes, arterial hypertension, chronic obstructive pulmonary disease, cardiovascular disease, and arthrosis) were assessed according to the answer to a direct question: "Has a doctor said that you suffer from any of the following diseases?" Comorbidities were classified as 1. none, 2. reporting one non-communicable disease, and 3. reporting two or more. Fall refers to the self-report of an episode within the past year (yes/no). 
Since the main focus of this study to assess the impact of social determinants of health in later life functioning trajectories, health status variables were considered as control variables.

\section{Statistical Analyses}

\section{Group-Based Trajectory Models}

Group-Based Trajectory Model (GBTM) is an unsupervised, model-based clustering technique used to recognize different patterns of temporal changes, such as typical or atypical courses of development of one or multiple outcomes ${ }^{24}$. In this study, bivariate GBTM $^{24,25}$ was applied to obtain data-driven longitudinal classes of BADL and IADL, which mapped their individual as well as their co-evolution. Censored Normal was used as link function for both outcomes.

\section{Model Fitting and Selection}

GBTM fitting was iterative and sequential. First, the number of latent trajectories was established (class-enumeration), with a gradual increment of latent classes and a fixed polynomial order (cubic) for both outcomes in each group. Subsequently, the polynomials orders determining the trajectories' level and shape was established by shrinking non-significant higher orders, one at a time (p-value $<0.15$ was assumed, once deletion of the higher orders looking for a reduction in $\mathrm{p}$-value implied in the increment of the BIC, considered as model deterioration).

In GBTM, model selection is customarily guided by different statistical model-fit criteria ${ }^{25}$. We evaluated the goodness-of-fit, and change of model-adequacy criterion as a function of the increasing number of latent classes, from one to eight. The goodness-of-fit criteria used to compare models with distinct number of classes the Akaike Information Criterion (AIC) and Bayesian Information Criterion (BIC) (1). Further, the class size was also a criterion, where the smallest group could not contain less than $3 \%$ of the sample assigned to each group (2). Other authors propose a minimum class size of $1 \%$; however, considering the initial sample size, attrition during the follow-up, and the methodology applied to describe group characteristics, we defined a more condescending criteria ${ }^{24}$. After model selection, all individuals had their posterior probability of assignment (PPA) to a class membership estimated. They were eventually assigned to the class for which they had the highest posterior probability. Throughout the whole process, the interpretability 
of extracted classes and their visual distinctiveness had a decisive role in the selection of the final model (4).

\section{Multinomial Logistic Regression}

Multinomial logistic models were fitted with the extracted bivariate functional trajectories as the dependent variable and socioeconomic covariates, the leading independent variables. Models were adjusted for additional covariates.

Conceptually, the multinomial analysis results in the relative-risk ratio to gauge the association between the outcome and each factor. However, from a technical perspective, the results achieved by multinomial logistic regression corresponds to the Odds Ratio (OR ${ }^{26}$. For this reason, we reported OR and $95 \%$ confidence intervals $(95 \% \mathrm{CI})$.

The statistical analysis used Stata version 15.1 (StataCorp, College Station, TX, 2019). Trajectory graphics and forest plots were made using the package ggplot2, from R, version 3.5.2.

\section{RESULTS}

At the baseline, the average age was $72.3( \pm 8.5)$. The sample was predominantly composed of women (59\%), white (nearly $3 / 4$ of individuals), and individuals who attended school for at least one full year (Table 1).

Figure 1-A displays the statistical fit criteria for models with 2 up to 8 classes. Six classes represented the best fit to the data, as informed by the BIC and AIC. After the polynomial order adjustment, the extracted bivariate trajectories are shown 1-B and 1-C. Each color represents one bivariate latent class, mapping the BADL and IADL individual paths plus their temporal links. For example, individuals assigned to the worst trajectory (Trajectory 6, in pink) had the highest average scores for both outcomes, i.e. a higher number of reported difficulties for BADL and IADL, with a low increase in the disabilities over the follow-up. Individuals assigned to this trajectory were not followed throughout the study period as they died or dropped out at some point, which explains the abrupt stop in the sequence of data in the last wave of the study (this trajectory ended in 2010).

Consistent with the hierarchy of functional loss, deterioration of instrumental activities preceded that of basic activities in trajectories 2, 3, 5 and 6. In trajectory 4, this time-structured 
decline of IADL-BADL was not observed, and in trajectory 1, decline of functional activities was not yet manifest.

\begin{tabular}{crrr}
\hline Figure 1-A. Model-fit statistical criterial \\
\hline $\begin{array}{c}\text { no. of latent } \\
\text { groups }\end{array}$ & $\begin{array}{c}\text { Distribution in } \\
\text { the smallest } \\
\text { group }\end{array}$ & BIC & AIC \\
\hline 2 & $42.7 \%$ & -9919.83 & -9877.30 \\
3 & $15.7 \%$ & -9752.03 & 9689.66 \\
4 & $8.2 \%$ & -9740.18 & -9657.97 \\
5 & $3.2 \%$ & -9705.61 & -9603.55 \\
6 & $3.8 \%$ & -9695.66 & -9573.75 \\
7 & $3.4 \%$ & -9697.52 & -9555.78 \\
8 & $1.8 \%$ & -9723.55 & -9561.96 \\
$6^{*}$ & $\mathbf{4 . 6 \%}$ & $\mathbf{- 9 7 1 5 . 9 6}$ & $\mathbf{- 9 6 1 9 . 5 7}$ \\
\hline
\end{tabular}

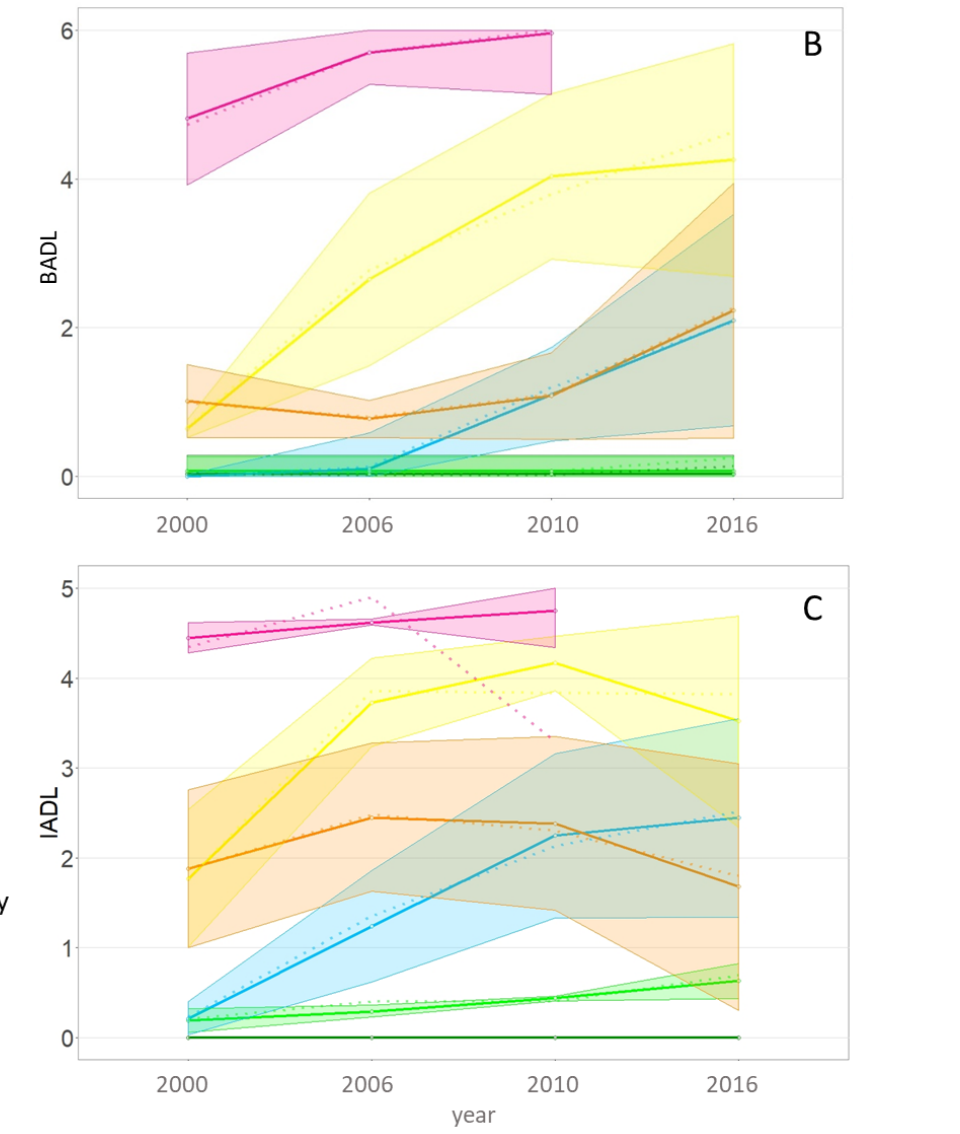

\section{Latent Trajectories}

Traj 1: Highly functional $(10,0 \%)$

Traj 2: Functional (38,3\%)

Traj 3: Accelerated impairment (12,8\%)

Traj 4: Fast impairment $(19,8 \%)$

Traj 5: Impairment process with IADL recovery Traj 6: Highly impaired ( 4,7\%)

Figure 1. Fit-model criteria - statistical criterion used to compare trajectories according to number of groups. The criteria were: percentual of individuals assigned to the smallest group and inferential criterion as BIC and AIC (A) and graphic representation of final model, with six latent groups, of basic (B) and instrumental (C) activities of daily living. Observed values (dots line), Estimated average (full line) and $95 \%$ confidence interval.

*Final model, after polynomial order adjustment.

\section{General Description}

Despite having similar starting points (little or no functional impairment at the beginning of follow-up), trajectories 1,2, and 3 diverged across time. While individuals assigned to trajectory 1 had no apparent ADL impairment during the whole follow-up, subjects in trajectory 2 remained with low levels of functional difficulties, but had a slight deterioration in IADL after the third wave. For trajectory 3, IADL visibly worsened after the wave 1 (as indicated by a steep increase in the average number of reported difficulties), foreshadowing the loss of BADL from wave 2 on 
(Figure 1). This hierarchic pattern of IADL/BADL decline was also detected in trajectories, 4 and 5, which, compared to the previous ones, had already a worse functional level at the outset. Between these two, trajectory 4 had a more accelerated functional decline than trajectory 5 in both ADLs. Notably, trajectory 4 had a rupture in the pattern of hierarchical increase of difficulties in IADL/BADL between the third and fourth waves when BADL continued to decline, while IADL did not (Figure 1).

Taken together, the bivariate trajectories show distinct stages in functional activities loss, evidencing the time-structured pattern of their deterioration, while laying bare the variability in terms of levels of onset and speed of functional decline.

\section{Particularities}

Trajectories 1 and 2, denoted, respectively, the highly functional and functional patterns of aging, encompassed nearly half of the sample. These trajectories were characterized by the best functional profile over time with no limitation to perform BADL and low incidence of difficulties (in the case of trajectory 2) during 16 years of follow-up. The highly functional trajectory (Traj1 $10 \%$ of the sample) had also the highest percentage of individuals with complete data (50\%), who were younger age at baseline compared to other classes $(76.2 \%$ had less than 70 years of age at the baseline). The Functional trajectory was the largest group, accounting to $38.3 \%$ of the sample; $48.6 \%$ of them were aged 60 to 69 years at the baseline. Both trajectories 1 and 2 had higher proportion of men than the remaining ones (50.0 and 47.5\%, respectively), low levels of illiteracy (7.9\% and 17.4\%) and cognitive impairment, and a lower prevalence of comorbidities (Table 1). 
Table 1. Distribution of older adults from Sao Paulo $(n=2,142)$ by functional trajectory groups, according sociodemographic characteristics and health situation. Sao Paulo, 2000-2016.

\begin{tabular}{|c|c|c|c|c|c|c|c|c|}
\hline & Traj 1 & Traj 2 & Traj 3 & Traj 4 & Traj 5 & Traj 6 & Total & $p$ value \\
\hline Total - n(\%) & $214(10)$ & $821(38.3)$ & $275(12.8)$ & $423(19.8)$ & $309(14.4)$ & $100(4.7)$ & $2,142(100)$ & \\
\hline \multicolumn{9}{|l|}{ Drop-out } \\
\hline Complete data & 50.0 & 14.5 & 27.3 & 5.7 & 9.7 & 0.0 & 16.6 & $<0.001$ \\
\hline Intermitente & 9.8 & 2.2 & 4.7 & 1.7 & 1.6 & 0.0 & 3.0 & \\
\hline Attrition & 40.2 & 83.3 & 68.0 & 92.6 & 88.7 & 100.0 & 80.4 & \\
\hline $\operatorname{Sex}(n)$ & 214 & 821 & 275 & 423 & 309 & 100 & 2142 & \\
\hline Male & 50.0 & 47.5 & 34.9 & 33.6 & 33.0 & 41.0 & 41.0 & $<0.001$ \\
\hline Female & 50.0 & 52.5 & 65.1 & 66.4 & 67.0 & 59.0 & 59.0 & \\
\hline Age (n) & 214.0 & 821.0 & 275.0 & 423.0 & 309.0 & 100.0 & 2142.0 & \\
\hline $60-69$ & 76.2 & 48.6 & 33.8 & 16.1 & 22.7 & 12.0 & 37.6 & $<0.001$ \\
\hline 70-79 & 22.9 & 38.4 & 46.9 & 40.9 & 35.7 & 31.0 & 37.7 & \\
\hline $80+$ & 0.9 & 13.0 & 19.3 & 43.0 & 41.6 & 57.0 & 24.7 & \\
\hline Skin color (n) & 201 & 767 & 263 & 404 & 298 & 96 & 2029 & \\
\hline White & 76.1 & 79.0 & 69.6 & 72.5 & 73.5 & 71.9 & & 0.023 \\
\hline Balck or brown (mixed) & 23.9 & 21.0 & 30.4 & 27.5 & 26.5 & 28.1 & 100.0 & \\
\hline \multicolumn{9}{|l|}{ Living alone } \\
\hline No & 86.9 & 83.7 & 85.8 & 81.1 & 83.2 & 96.0 & 84.3 & 0.008 \\
\hline Yes & 13.1 & 16.3 & 14.2 & 18.9 & 16.8 & 4.0 & 15.7 & \\
\hline \multicolumn{9}{|l|}{ Education } \\
\hline Attended to school (n) & 214 & 821 & 275 & 423 & 309 & 99 & 2141 & \\
\hline Yes & 92.1 & 82.6 & 76.0 & 59.6 & 69.9 & 64.7 & 75.5 & $<0.001$ \\
\hline No & 7.9 & 17.4 & 24.0 & 40.4 & 30.1 & 35.3 & 24.5 & \\
\hline Educational level (n) & 213 & 819 & 274 & 417 & 306 & 95 & 2124 & \\
\hline None & 7.9 & 17.4 & 23.7 & 41.0 & 30.3 & 37.9 & 24.7 & $<0.001$ \\
\hline Low-level & 25.8 & 26.3 & 28.5 & 28.5 & 27.8 & 32.6 & 27.5 & \\
\hline Middle & 36.2 & 35.3 & 36.1 & 22.1 & 32.7 & 24.2 & 32.0 & \\
\hline High & 30.1 & 21.0 & 11.7 & 8.4 & 9.2 & 5.3 & 15.8 & \\
\hline \multicolumn{9}{|l|}{ Economic situation at baseline } \\
\hline Economic sufficiency (n) & 213 & 810 & 272 & 414 & 301 & 95 & 2105 & \\
\hline Yes & 42.7 & 35.3 & 32.8 & 26.6 & 24.9 & 17.9 & 31.7 & $<0.001$ \\
\hline No & 57.3 & 64.7 & 67.2 & 73.4 & 75.1 & 82.1 & 68.3 & \\
\hline \multicolumn{9}{|l|}{ Current health characteristics (2000) } \\
\hline Self-rated health (n) & 214 & 821 & 274 & 421 & 308 & 100 & 2138 & \\
\hline Excelent/Very good/Good & 64.5 & 52.7 & 50.0 & 33.5 & 27.6 & 23.0 & 44.8 & $<0.001$ \\
\hline Regular/Poor & 35.5 & 47.3 & 50.0 & 66.5 & 72.4 & 77.0 & 55.2 & \\
\hline Cognitive Impairment (n) & 214 & 821 & 275 & 423 & 309 & 100 & 2142 & \\
\hline No & 97.7 & 95.4 & 92.4 & 66.9 & 71.2 & 14.0 & 82.3 & $<0.001$ \\
\hline Yes & 2.3 & 4.6 & 7.6 & 33.1 & 28.8 & 86.0 & 17.7 & \\
\hline Number of chronic conditions ( $n$ ) & 2154 & 821 & 275 & 423 & 309 & 100 & 2142 & \\
\hline None & 40.7 & 25.5 & 26.6 & 18.7 & 14.6 & 17.0 & 23.8 & $<0.001$ \\
\hline One & 34.1 & 33.9 & 32.7 & 27.0 & 23.0 & 17.0 & 30.0 & \\
\hline Two or more & 25.2 & 40.6 & 40.7 & 54.3 & 62.4 & 66.0 & 46.2 & \\
\hline Fall in the last year $(n)$ & 213 & 821 & 275 & 423 & 309 & 100 & 2141 & \\
\hline No & 79.8 & 74.8 & 69.1 & 61.5 & 56.6 & 51.0 & 68.2 & $<0.001$ \\
\hline Yes & 20.2 & 25.2 & 30.9 & 38.5 & 43.4 & 49.0 & 31.8 & \\
\hline
\end{tabular}


Individuals assigned to Trajectory 3 - Accelerated impairment trajectory - aged with accelerated functional impairment in both group of activities (BADL and IADL). This trajectory had the higher participation of black/brown ethnicity (30.4\%), women (65.1\%), and illiterate individuals (23.7\%). Almost half of them (46.9\%) were in their seventies at baseline. Around 2/3 had no economic sufficiency.

Fast impairment trajectory (Traj 4) presented the most accelerated process BADL and IADL decline compared to trajectory 5 (Impairment process with IADL recovery). With respect to socioeconomic characteristics, they were mostly composed of women (66.4 and 67\%, respectively), older individuals (more than $40,0 \%$ were 80 years or older at baseline), and illiterate people (41.0\% in trajectory $4,30.3 \%$ in trajectory 5$)$.

The highly compromised trajectory (Trajectory 6 - Highly impaired) was the smallest (4.7\%). Subjects assigned to this group had the most disadvantageous profile. In addition to having been lost to the last the follow-up period, they were the oldest at baseline (57\% were 80 or older), had a high prevalence of cognitive impairment (86\%), the worst health status, and large proportion individuals reporting falls in the last year (Table 1). This group also had the lowest percentual of individuals living alone (4\%),

Without exception, all variables related to health conditions showed a graded association with the trajectories. The highly functional trajectory had the best health indicators, with better perception of health, a higher percentage of individuals with preserved cognitive function, less

prevalence of chronic diseases and less occurrence of falls in the last year. But, as one moves from trajectory 1 to 6 , all the characteristics gradually deteriorate, with worse outcomes occurring in the trajectory 6 - Highly impaired trajectory.

\section{Multinomial Regression}

The multinomial regression category of reference was the Functional Trajectory (Traj 2).

The Highly functional (Traj 1) and the Accelerated impairment (Traj 3) trajectories were more associated with socioeconomic characteristics than by health characteristics, whereas the Impairment process with IADL recovery (Traj 5) and the Highly impaired (Traj 6) trajectories were more linked to health characteristics. The Fast impairment trajectory (Traj 4) was linked with both groups of independent variables since it associated significantly with educational level and also with health conditions- considered as control variables - in relation of the Functional trajectory (Traj 2). 
Individuals from the Highly functional trajectory (1) were mainly younger (OR $70-79$ years old 0.40; 95\% CI $0.27 ; 0.58 \mid \mathrm{OR}_{80+} 0.05 ; 95 \%$ CI $\left.0.01 ; 0.22\right)$ and were less likely to be illiterate $\left(\mathrm{OR}_{\text {illiterate }} 0.44 ; 95 \% \mathrm{IC} 0.23 ; 0.86\right)$ and to report chronic diseases (OR One chronic disease 0.66; 95\% IC $0.45 ; 0.98 \mid \mathrm{OR}_{\text {Two or more }} 0.43 ; 95 \%$ IC $\left.0.28 ; 0.66\right)$ in relation to individuals in trajectory 2 . Older individuals were more likely to follow trajectories 3 to 6 .

In comparison to the Functional trajectory, individuals in trajectories 3 and 4 (Accentuated impairment trajectory and Fast impairment trajectory, respectively) were more likely to be

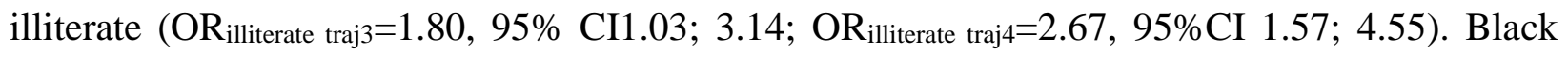
individuals were more likely to follow Accentuated impairment trajectory $(\mathrm{OR}=1.57,95 \% \mathrm{CI} 1.12$; 2.22), even in a model adjusted for other socioeconomic indicators.

Older adults with perceived financial insufficiency $\left(\mathrm{OR}_{\text {traj }}=1.59,95 \% \mathrm{CI} 1.12 ; 2.25\right.$; $\mathrm{OR}_{\text {traj6}}=2.46,95 \% \mathrm{CI} 1.24 ; 4.86$ ) presented higher odds to be on the Impairment process with IADL recovery and Highly impaired trajectories. They also had poorer self-rated health, were more likely to have an impaired cognitive function, co-morbidities, and to report falls in the precedent year than individuals assigned to the Functional trajectory. Individuals in Fast impairment trajectory (4) had a similar profile.

There was no gender influence in trajectories 1 and 6 (Highly functional trajectory and Highly impaired trajectory - respectively), aspect particularly interesting because these are completely opposite trajectories. 
Table 2. Adjusted analysis for each bivariate functional trajectory with respect to Trajectory 2 and for additional associated factors, estimated by the multinomial regression model.

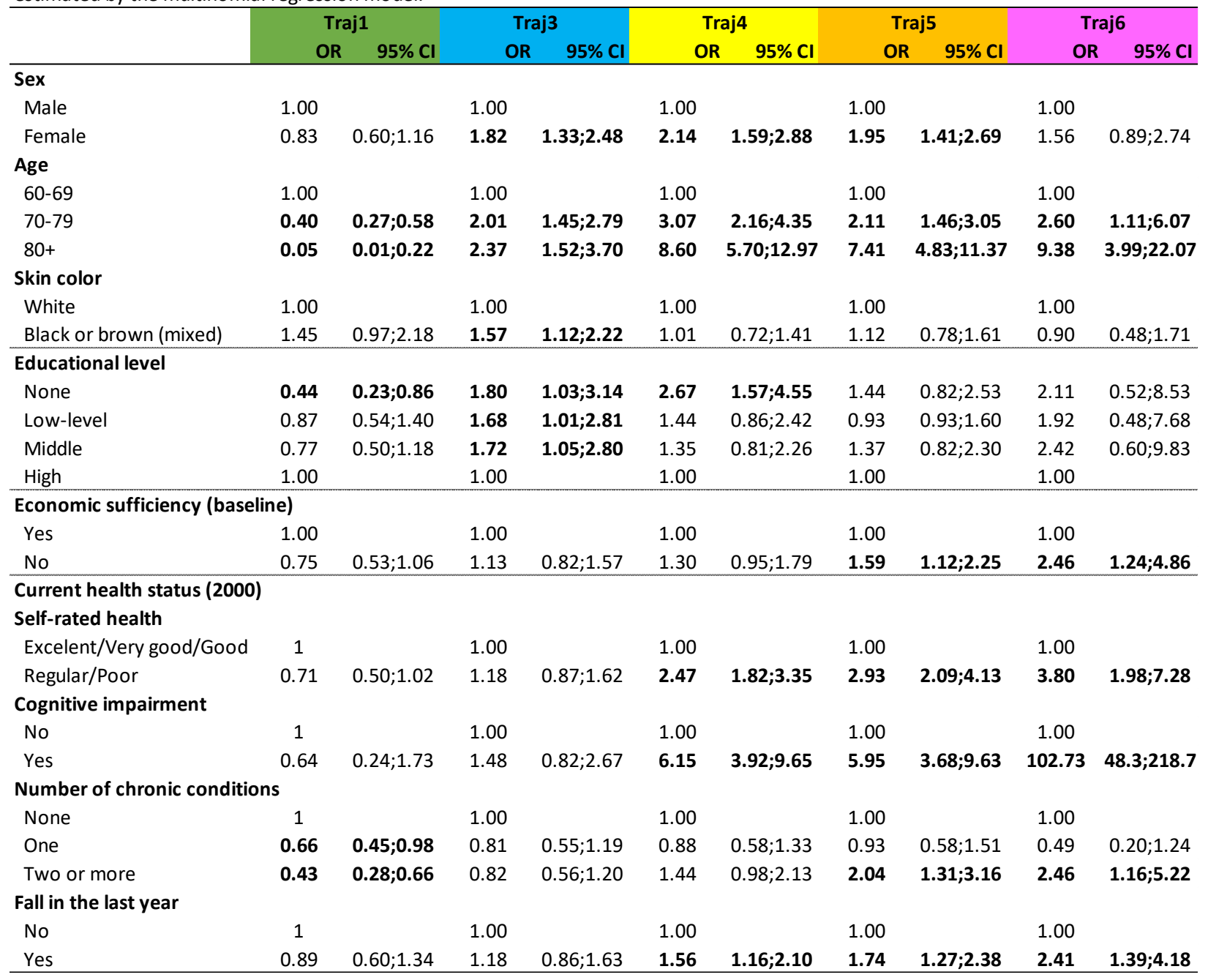

\section{DISCUSSION}

We used group-based trajectory model to identify bivariate functional trajectories of BADL and IADL in older adults living in São Paulo, Brazil, who were followed-up for 16 years. The present findings showed functional transitions of aging to be heterogeneous in their courses. Six trajectories were extracted reflecting a broad spectrum of IADL and BADL patterns of changes, ranging from high-functional up to vulnerable. The magnitude and speed of these changes were variable. For most trajectories, the decline of IADL preceded that of BADL, confirming their timestructured hierarchy. Consistent with previous studies ${ }^{27,28}$, older ages and females were more prevalent in worse-off trajectories. Further, the more vulnerable paths, characterized by accelerated deterioration or high impairment, were linked to disadvantageous socio-economic 
characteristics, such as race and educational level, even after controlling for proximal health characteristics and age.

To our knowledge, this is the first article that assesses the temporal co-dependency of basic and instrumental activities. Past researches made use of only BADL indicators, such as total score ${ }^{14,19,29}$. One of the strengths of our study was to reveal intermediate trajectories between what is customarily described the best ${ }^{30,31}$ and the worse ${ }^{32}$ in the literature. Further, despite the validation of hierarchical pattern of IADL and BADL loss, for one trajectory, this hierarchy was less clear-cut. For other authors, the basic and instrumental activities are interdependent but do not necessarily follow a structured rule in which instrumental activities precede the limitation in basic activities, consistent with the results of Bendayan et $\mathrm{al}^{6}$. One of the aspects influencing the observed recovery is the presence of some kind of social support (e.g. tangible support, as helping shopping) as suggested by previous research ${ }^{33-35}$. As older adults survive through the lifespan, the community, family and neighborhood could provide some settings to facilitate maintaining the independence of functional abilities ${ }^{35}$.

The differential sex distribution among the trajectories, with higher proportion of females in more disadvantaged functional profiles, reflects, to some degree, females' higher life expectancy with increased risk of suffering time-related impairments ${ }^{36}$ (e.g. higher prevalence of arthritis in women). But this is not the whole story. Sexism is also an implicit variable when studying sex differences in health outcomes ${ }^{37}$, particularly in a country like Brazil. Hence, the observed male/female divide in functionality can be, further, an expression of social construction differences and of the cultural factors and behaviors learned throughout life. Unequal societies expose women to more discrimination, unequal opportunities, repression and violence, which are ultimately reflected in worse functional conditions at old ages ${ }^{38}$.

Still within the context of sex effect, it should be noted that, despite a higher prevalence of females in the vulnerable trajectory 6 , no statistical difference was observed in its comparison with the reference group (functional trajectory 2). This is likely attributable to the reduced statistical power because of the former's small size. However, in line with the findings of Ferrucci et $\mathrm{al}^{39}$, this could, alternatively, indicate that biological sex plays a lesser role in the disability processes for individuals in extreme stages of limitation. Similarly, to the argument of Ferrucci et $\mathrm{al}^{39}$, we further contend that sex's role on ageing may be minimized for individuals living in more equitable 
and advantageous socio-economic conditions. The lack of sex differences in the highly functional vs. functional comparison would support this possibility.

Evidence from previous studies hints at the life course cumulative effect of socioeconomic factors on health in late life ${ }^{40,41}$. Lower educational level, for instance, has been associated with an accelerated process of functional decline ${ }^{16}$. However, the effect of education implies that underlying paths related with years of formal education are critical in defining functioning in older ages. Among the ways in which education can promote such consistent effects in late trajectories, we can mentioned the accumulation of health-related knowledge and the power of education in promoting better work opportunities and income situation in adult life $\mathrm{e}^{42,43}$. In addition, education also reflects psychosocial resources and influences the position an individual occupies in society ${ }^{44}$. We can summarize that the selective social differences during the life course based or influenced by education plays an important role in later life functional trajectories.

Our results back-up the putative the socio-economic cumulative impact. Of note, adjustment for scholarly level and for other health variables was not sufficient to attenuate the link between vulnerable trajectories and being black. In contrast to the results of Brown and colleagues ${ }^{45}$, skin color remained a factor that independently increased the risk of accelerated functional decline. This result accords with two social theories: the cumulative disadvantage/advantage discourse ${ }^{46}$, that contends that socioeconomic characteristics accumulate throughout life, ultimately impacting the ageing process; and the institutional racism theory, that deals with how differences in social constructs based on race/ethnicity affect health throughout the life cycle ${ }^{47,48}$.

In Brazil, the skin color is much more than a demographic aspect. It remains, to date, tightly linked the socio-economic position, partially guiding Brazilians towards opportunities (or lack thereof). Black individuals are known to have limited access to social institutions, such as schools and health services, that can lead to worse health conditions ${ }^{47-49}$. The herein observed association between black ethnicity and poor health is possible attributed to the rigidity of the social constructions, providing supportive evidence for institutional racism.

Specifically, regarding health characteristics, the early-onset of cognitive impairment also reflects worse physical functioning at baseline, being both functional measures co-dependent and, additionally, when cognitive impairment comes first, it could promote an accelerated decline in physical function of older adults ${ }^{50,51}$. 
Subjects' class membership was more strongly affected by health factors for functional trajectories characterized by more limitations at the beginning (here the trajectories 4,5 and 6). Conversely, socioeconomic factors prevailed in their links to trajectories with low-disability starting points (here the trajectories 1,2 and 3). However, we must not ignore that the worst health conditions are also primarily influenced by socioeconomic disadvantages accumulated during $\operatorname{life}^{40,52}$.

\section{Limitations}

Given the gradual and increasing age progression from the highly functional up to vulnerable trajectories, the unveiled heterogeneity may strike, at first, as a design artefact. If so, the different levels and slopes of the six uncovered trajectories are reflecting distinct temporal windows (snapshots along the time line) of a hidden continuum rather than capturing true heterogeneity. In this way, the overlaid longitudinal profiles (figure 1) represent transitional stages of one overall underlying pattern of functional deterioration. Were these trajectories to be extended over a time scale of chronological age, instead of the discrete four periods of follow-up, they would not be superimposed, but possibly in an overlapping succession. Accordingly, subjects assigned to e.g. trajectory 1 would, as they age, transit to a trajectory 2 profile, and this to e.g. trajectory 3 etc. Although we cannot fully eliminate this possibility, an admonition is warranted. First, the distinct age compositions of the trajectories mean that these subjects came from different cohorts, and, as such, they lived according to the social rules and cultural norms that influenced individuals' life. Second, the way socioeconomic features affected class membership, independent of age, elicit evidence for an underlying heterogeneous life course process generating differential ageing.

A further limitation of our study was the use self-reported information. We did not compare the answers about performance testing. However, a systematic review found moderate to large correlation between performance-based and self-reported measures when assessing BADL, IADL and performed mobility ${ }^{55}$.

One of the major difficulties in conducting cohorts of older adults is the high percentage of attrition, which generally affects the oldest and most vulnerable individuals ${ }^{56}$. Following elder from a middle-income country, during 16 years is particularly challenging, but this type of study offers a great opportunity to analyze the life course aspects and its influence on aging.

We observed a clear differential attrition among the extracted trajectories. As expected, the paths with accelerated impairment and the most vulnerable class had a substantially higher dropout 
rate. Loss to follow-up was higher for men, older individuals, less educated and those referring more comorbidities, consistent with those reported in other studies ${ }^{56,57}$. These features are not only linked to attrition, but too often characterize people refusing to participate in the follow-up ${ }^{53}$. Lastly, in Brazil, black older adults age in worse conditions than brown ones ${ }^{49}$, but the large attrition rate and the shrinking sample size precluded us from analyzing these categories separately.

Implications

Uncovering and mapping the heterogeneity of functional trajectories facilitates the identification of subjects at 'high risk' of future functional decline. Besides, understanding the temporal processes and specifics factors generating their heterogeneity facilitates the recognition of venues for actionable intervention. For instance, at individual level, implementing physical activity routines could postpone functional decline in respect of instrumental and basic activities ${ }^{54}$. These routines could be further reinforced by educational groups. Teaching coping and adaptation strategies could benefit older adults and improve their functional prospects ${ }^{27,55}$. Further, health policies should be integrated with educational projects focusing the development of skills related to self-governance and resilience. In this regard, environmental adaptations would be also much welcomed, since life outside home would enhance the independence of more vulnerable individuals. Maintaining sidewalk walkability, resting places in the path, training drivers to be more responsive to the older adults' needs are examples of investments that could promote a more friendly city. It seems appropriate to quote an excerpt from Michael Marmot's book ${ }^{18}$ : At the end of every scientific paper there is a familiar coda: more research is needed; more research is needed. What, I wondered, if we added a new coda: mode action is needed. It need not be discordant with the first. (p.17).

\section{Conclusion}

The unveiled dynamics of the BADL/IADL bivariate trajectories captured the heterogeneity of functional loss in Brazilian older adults. The findings indicate that, although functional decline is an individual process, its putative underlying causes are not restricted to the individual biological make-up nor individual agency only. Inequalities during the life course emerged as a potential socio-economic force associated with differential aging, independent of age. For this reason, public policies need to focus on decreasing these inequalities, investing in 
access to education, and restructuring institutions for inclusion, especially concerning women and racial groups. It is not easy to change institutional racism and sexism in Brazil, but, in this multicultural and racially mixed country, this is a critical point that could improve the prospects of healthy aging for older populations.

\section{Reference}

1. WHO. WHO | World report on ageing and health 2015. WHO. World Health Organization; 2015.

2. Cornelis E, Gorus E, Van Schelvergem N, De Vriendt P. The relationship between basic, instrumental, and advanced activities of daily living and executive functioning in geriatric patients with neurocognitive disorders. Int J Geriatr Psychiatry. 2019;34(6):889-99.

3. Katz S, Ford AB, Moskowitz RW, Jackson BA, Jaffe MW. Studies of Illness in the Aged. The Index of ADL: a standardized meadure of biological and psychosocial function. J Am Med Assoc. 1963;185(12):914-9.

4. Lawton MP, Brody EM. Assessment of older people: self-maintaining and instrumental activities of daily living. Gerontologist. 1969;9(3):179-86.

5. Ferrucci L, Guralnik JM, Cecchi F, Marchionni N, Salani B, Kasper J, et al. Constant hierarchic patterns of physical functioning across seven populations in five countries. Gerontologist. 1998;38(3):286-94.

6. Bendayan R, Cooper R, Wloch EG, Hofer SM, Piccinin AM, Muniz-Terrera G. Hierarchy and Speed of Loss in Physical Functioning: A Comparison Across Older U.S. and English Men and Women. Journals Gerontol Ser A Biol Sci Med Sci. 2016;72(8).

7. Gerrard P. The hierarchy of the activities of daily living in the Katz index in residents of skilled nursing facilities. J Geriatr Phys Ther. 2013;36(2):87-91.

8. Liang J, Wang C-N, Xu X, Hsu H-C, Lin H-S, Lin Y-H. Trajectory of functional status among older Taiwanese: Gender and age variations. Soc Sci Med. 2010;71(6):1208-17.

9. French R, Steele F. Trajectories of functional disability for the elderly in Britain. Longit Life Course Stud. 2015;6(3).

10. Zimmer Z, Bao L, Mayol NL, Chen F, Perez TLL, Duazo PL. Functional limitation trajectories and their determinants among women in the Philippines. Demogr Res. 2017;36:863-92.

11. Stuck AE, Walthert JM, Nikolaus T, Büla CJ, Hohmann C, Beck JC. Risk factors for functional status decline in community-living elderly people: a systematic literature review. Soc Sci Med. 1999;48(4):445-69. 
12. Fuentes-García A, Sánchez H, Lera L, Cea X, Albala C. Desigualdades socioeconómicas en el proceso de discapacidad en una cohorte de adultos mayores de Santiago de Chile. Gac Sanit . 2013;27(3):226-32.

13. Gill TM, Gahbauer EA, Han L, Allore HG. Trajectories of disability in the last year of life. N Engl J Med . 2010;362(13):1173-80.

14. Díaz-Venegas C, Wong R. Trajectories of limitations in activities of daily living among older adults in Mexico, 2001-2012. Disabil Health J. 2016;9(3):524-32.

15. Haas S. Trajectories of functional health: The "long arm" of childhood health and socioeconomic factors. Soc Sci Med. 2008;66(4):849-61.

16. Xu X, Liang J, Bennett JM, Botoseneanu A, Allore HG. Socioeconomic stratification and multidimensional health trajectories: Evidence of convergence in later old age. Journals Gerontol - Ser B Psychol Sci Soc Sci. 2015;

17. Bernardi L, Huinink J, Settersten RA. The life course cube: A tool for studying lives. Adv Life Course Res. 2018;100258.

18. Marmot M. The health gap : the challenge of an unequal world. 2015.

19. Torres JM, Rizzo S, Wong R. Lifetime Socioeconomic Status and Late-life Health Trajectories: Longitudinal Results From the Mexican Health and Aging Study. Journals Gerontol Ser B Psychol Sci Soc Sci. 2016;73(2):349-60.

20. Lebrão ML, Duarte YA de O, Santos JLF, Silva NN da, Lebrão ML, Duarte YA de O, et al. 10 Anos do Estudo SABE: antecedentes, metodologia e organização do estudo. Rev Bras Epidemiol. 2019;21(suppl 2).

21. Lawton MP. The functional assessment of elderly people. J Am Geriatr Soc. 1971;19(6):465-81.

22. Osorio RG. Texto para discussão n.996 - O sistema classificatório de "Cor ou Raça" do IBGE. Brasília; 2003.

23. Folstein MF, Folstein SE, McHugh PR. "Mini-mental state". A practical method for grading the cognitive state of patients for the clinician. J Psychiatr Res. 1975;12(3):189-98.

24. Nagin DS, Jones BL, Lima Passos V, Tremblay RE. Group-based multi-trajectory modeling. Stat Methods Med Res. 2018;27(7):2015-23.

25. Klijn SL, Weijenberg MP, Lemmens P, van den Brandt PA, Lima Passos V. Introducing the fit-criteria assessment plot - A visualisation tool to assist class enumeration in groupbased trajectory modelling. Stat Methods Med Res. 2017;26(5):2424-36.

26. StataCorp. Stata 15 Base Reference Manual. College Station, Tx: Stata Press; 2017. 2997 p. 
27. LaPlante MP. The Classic Measure of Disability in Activities of Daily Living Is Biased by Age but an Expanded IADL/ADL Measure Is Not. Journals Gerontol Ser B Psychol Sci Soc Sci. 2010;65B(6):720-32.

28. Verbrugge LM, Latham K, Clarke PJ. Aging With Disability for Midlife and Older Adults. Res Aging. 2017;39(6):741-77.

29. Martin LG, Zimmer Z, Lee J. Foundations of Activity of Daily Living Trajectories of Older Americans. J Gerontol B Psychol Sci Soc Sci. 2017 ;72(1):129-39.

30. Han L, Allore H, Murphy T, Gill T, Peduzzi P, Lin H. Dynamics of functional aging based on latent-class trajectories of activities of daily living. Ann Epidemiol. 2013;23(2):87-92.

31. Chen C-M, Su Y-Y, Mullan J, Huang M-S, Chiu H-C. Trajectories of Disability and Their Relationship with Health Status and Social Service Use. Exp Aging Res. 2015;41(3):24058 .

32. Gill TM, Gahbauer EA, Han L, Allore HG. Trajectories of Disability in the Last Year of Life. N Engl J Med. 2010;362(13):1173-80.

33. Marino P, Sirey JA, Raue PJ, Alexopoulos GS. Impact of social support and self-efficacy on functioning in depressed older adults with chronic obstructive pulmonary disease. Int J COPD. 2008;3(4):713-8.

34. Kiefer R. The Effect of Social Support on Functional Recovery and Well-Being in Older Adults Following Joint Arthroplasty. Rehabil Nurs.2001;36(3):120-6.

35. Uchino BN, Bowen K, Kent de Grey R, Mikel J, Fisher EB. Social Support and Physical Health: Models, Mechanisms, and Opportunities. In: Principles and Concepts of Behavioral Medicine. Springer New York; 2018. p. 341-72.

36. Gill TM, Gahbauer EA, Lin H, Han L, Allore HG. Comparisons Between Older Men and Women in the Trajectory and Burden of Disability Over the Course of Nearly 14 Years. J Am Med Dir Assoc . 2013;14(4):280-6.

37. Fiske ST, Psychol P, Author S. Prejudices in Cultural Contexts: Shared Stereotypes (Gender, Age) versus Variable Stereotypes (Race, Ethnicity, Religion). Perspect Psychol Sci. 2017;12(5):791-9.

38. Ahmed T, Vafaei A, Auais M, Guralnik J, Zunzunegui MV. Gender Roles and Physical Function in Older Adults: Cross-Sectional Analysis of the International Mobility in Aging Study (IMIAS). PLoS One. 2016;11(6):e0156828.

39. Ferrucci L, Guralnik JM, Simonsick E, Salive ME, Corti C, Langlois J. Progressive versus catastrophic disability: a longitudinal view of the disablement process. J Gerontol A Biol Sci Med Sci. 1996;51(3):M123-30.

40. Link BG, Phelan J. Social Conditions As Fundamental Causes of Disease. J Health Soc 
Behav. 1995;35:80-94.

41. Ferraro KF, Morton PM. What Do We Mean by Accumulation? Advancing Conceptual Precision for a Core Idea in Gerontology: Table 1. Journals Gerontol Ser B Psychol Sci Soc Sci. 2016;73(2):269-78.

42. Hoffmann R, Kröger H, Pakpahan E. Pathways between socioeconomic status and health: Does health selection or social causation dominate in Europe? Adv Life Course Res. 2018 Jun 1;36:23-36.

43. Pakpahan E, Hoffmann R, Kröger H. The long arm of childhood circumstances on health in old age: Evidence from SHARELIFE. Adv Life Course Res. 2017;31:1-10.

44. Elo IT. Social Class Differentials in Health and Mortality: Patterns and Explanations in Comparative Perspective. Annu Rev Sociol. 2009;35(1):553-72.

45. Brown TH, O'Rand AM, Adkins DE. Race-Ethnicity and Health Trajectories. J Health Soc Behav. 2012;53(3):359-77.

46. Dannefer D. Systemic and Reflexive: Foundations of Cumulative Dis/Advantage and LifeCourse Processes. Journals Gerontol Ser B. 2018;

47. Werneck J. [Institucional racism and black population health]. Saude Soc. 2016;25(3):53549.

48. Silva A da, Rosa TE da C, Batista LE, Kalckmann S, Louvison MCP, Teixeira DS da C, et al. Racial inequities and aging: analysis of the 2010 cohort of the Health, Welfare and Aging Study (SABE). Rev Bras Epidemiol. 2019;21(suppl 2).

49. Braga LDS, Caiaffa WT, Ceolin APR, De Andrade FB, Lima-Costa MF. Perceived discrimination among older adults living in urban and rural areas in Brazil: A national study (ELSI-Brazil). BMC Geriatr. 2019;19(1):67.

50. Njegovan V, Man-Son-Hing M, Mitchell SL, Molnar FJ. The Hierarchy of Functional Loss Associated With Cognitive Decline in Older Persons. Journals Gerontol Ser A Biol Sci Med Sci. 2001;56(10):M638-43.

51. Han L, Gill TM, Jones BL, Allore HG. Cognitive Aging Trajectories and Burdens of Disability, Hospitalization and Nursing Home Admission Among Community-living Older Persons. J Gerontol A Biol Sci Med Sci. 2016;71(6):766-71.

52. Saenz JL, Wong R. Educational Gradients and Pathways of Disability Onset Among Older Mexicans. Res Aging [Internet]. 2016;38(3):299-321.

53. Silva Junior SHA, Santos SM, Coeli CM, Carvalho MS. Assessment of participation bias in cohort studies: systematic review and meta-regression analysis. Cad Saude Publica. 2015;31(11). 
54. McPhee JS, French DP, Jackson D, Nazroo J, Pendleton N, Degens H. Physical activity in older age: perspectives for healthy ageing and frailty. Biogerontology. 2016 Jun 1;17(3):567-80.

55. Baltes MM. The many faces of dependency in old age. 1 Ed. New York: Cambridge University Press; 1996. 1-204 p. 


\title{
Artigo 3 - Highways to Ageing - Linking life course SEP to multivariate trajectories of health outcomes in older adults
}

Autores: Etienne Duim, Valéria Lima Passos

\begin{abstract}
Objectives: Ageing is a temporal, multi-faceted process, whose unfolding is subject to a several interacting factors: e.g. genetic, environmental/contextual, behavioral and socio-economic. In this study, we used life course and multidimensional approaches to elucidate the association between socioeconomic forces across a lifetime and the developmental origins in health and disease of the Mexican elderly.
\end{abstract}

Methods: Data stemmed from the Mexican Health and Ageing Study, constituting a sample of older adults $(\mathrm{N}=5169,>50$ years $)$. With retrospective information on early, intermediary and current socioeconomic indicators, life course typologies of socioeconomic position were identified using Latent Class Analysis. Based on prospective data of functional mobility, number of chronic conditions and self-rated health, multivariate trajectories of health outcomes were uncovered with Group Based Trajectory Model. Links between the extracted SEP and multivariate health latent constructs were explored with multinomial logistic regression.

Results: Life course SEP classes were heterogeneous, yet a large proportion of subjects was characterized by persistent socioeconomic adversity throughout life. The outcomes' patterns of co-evolution were diverse too, shedding light on the strength of their temporal links, while revealing variable synchronicity in their temporal decline. Lastly, a conspicuous graded 
association was observed between the SEP classes and ageing trajectories, with subjects of less advantageous SEP classes being more likely to age vulnerably.

Conclusion: Ageing is not one-model fits all process of deterioration but, rather, naturally variable. The findings provide life course evidence for the distinct ways socio-economic forces can shape ageing developmental courses. 


\section{Background}

A confluence of two conceptual frameworks has characterized increasing efforts to tackle and understand the complexity of the ageing process: 'successful ageing', and the 'life course approach to health and disease, ${ }^{1-5}$. The broad model of successful ageing (SA) 5 implies multifaceted changes. Its operationalization encapsulates several indicators of the physical, cognitive and subjective evaluation of health, in addition to productivity and social engagements ${ }^{6-}$ ${ }^{9}$. Since its introduction in 1987, SA has advanced to incorporate a developmental perspective, which accounts for the impact of time, (duration of) critical periods, timing and/or turning points on the development of health and disease in later life. Of particular interest in the developmental approach is the role of socioeconomic inequalities. People vary in their ageing, and there is mounting evidence of the role that socio-economic forces play in generating this variation. Framing ageing as a lifelong process above individual agency by accounting for socioeconomic circumstances has been in speedy ascent in epidemiological social and gerontology's studies ${ }^{3,4}$.

Different theoretical frameworks have been used to conceptualize the role of socioeconomic inequalities in health, e.g. Cumulative Advantage/Disadvantaged Theory (CA/DT) ${ }^{10,11}$ and the Age as Leveler Hypothesis (AAL) ${ }^{12,13}$. Simply stated, the former posits that any initial socioeconomic relative (dis)advantage will persist and/or accumulate across a life course in a systemic way, whereas in the latter, the sway of early socioeconomic adversity on later life health may be superseded by e.g. biological factors, which can become more relevant in shaping health decline.

To date, evidentiary support for CA/DT is compelling and burgeoning ${ }^{5,14-26}$. Different studies have shown how adverse socioeconomic exposures during early life impact adult and older 
adults through direct or indirect pathways ${ }^{14,27}$. They have suggested a cumulative effect of socioeconomic exposures during childhood on well-being and quality of life that is mediated by adulthood circumstances ${ }^{16,17}$ and possibly moderated by sex, with worse prospects for women ${ }^{5,28}$. Similarly, investigations on cardiovascular disease ${ }^{29}$ mortality risk ${ }^{29}$ and risk of stroke ${ }^{19}$ were explained by the duration of poor socio-economic position (SEP) throughout life ${ }^{20}$. Disadvantageous SEP has also been linked to physical disabilities and functional deterioration ${ }^{21}$, especially when taking the length of adversity ${ }^{22-26}$ into account. However, Sacker and colleagues ${ }^{30}$ indicated that it is possible to see the impact of early social inequalities diluting, in particular when social mobility occurs. Evidence for convergence in health conditions among older adults, in spite of e.g. racial inequalities ${ }^{31}$ and educational level ${ }^{32}$ supports the AAL model.

Be it CA/DT or AAL, the current consensus is that multiple mechanisms may explain the links between socioeconomic inequalities and health in general, and ageing, specifically ${ }^{26,33,34}$. Thus, the two life-course perspectives are not necessarily mutually exclusive. Recent findings revealing substantial heterogeneity in developmental trajectories of distinct ageing outcomes buttress the idea of multiple causal chains. These studies ${ }^{18,28,35}$ have provided insights into the lifeexposures and processes underlying such heterogeneity, showing that life-long low SEP predicted morbidity in later life ${ }^{18,35}$, as well as how inter-generational social mobility impacted health condition in older ages ${ }^{28}$.

Most of these studies have focused either on the life-course aspects of ageing or on SA. Despite recent endeavors ${ }^{36-39}$ to tackle both of them simultaneously, the run of the mill in developmental research remains the investigation of one (SA) outcome at a time, even in multivariate settings ${ }^{40}$. The shortcoming of such an approach is that it fails to capitalize on any information that may be contained in the concurrency and interdependency of different outcomes. 
For example, are there distinct patterns of co-evolution among the SA variables? If yes, could they assist in the identification and characterization of distinct processes underlying differential ageing? Moreover, when specifically addressing the SEP impact on ageing, researchers face additional methodological challenges. Despite the abundance of SEP indicators, they are not always measured across the long arch of a life time, and this can obscure their inherent temporality, i.e. stability, transience, reversibility, erratic or steady nature of changes. Add to that the fact that, when several SEP indices are available in one study (years at school, as past SEP, and current income as its contemporaneous counterpart), traditional multivariable models often disregard their underlying mediating chains. Thus, tackling ageing from multidimensional and developmental perspectives, as well as elucidating SEP's role is challenging, ambitious, but ultimately incumbent in gerontological research. Notably, modern statistical methods like model-based clustering techniques have been instrumental in harnessing the complexity of longitudinal and multivariate data information ${ }^{37}$.

True to that, our objective was multifold. We aimed to identify life course SEP typologies using retrospective data on several socioeconomic indicators from older individuals (age $\geq 50$ at baseline) of the longitudinal Mexican Health and Ageing Study. Several categorical SEP indices were available at different life stages, which were amalgamated into data-driven SEP classes using Latent Class Analysis (LCA). With the prospective data on the same subjects, multivariate ageing trajectories with Group-Based Trajectory Model (GBTM) were uncovered based on three health outcomes: mobility, number of non-communicable diseases and subjective evaluation of health, all of which core constituents of Successful Ageing ${ }^{2,8,9}$. The advantage of the multivariate model is that the extracted trajectories capture the evolution of each individual outcome, while 
simultaneously mapping the heterogeneity of their temporal linkages. Lastly, the links between the unveiled life-course SEP classes and the multivariate ageing trajectories were explored.

\section{Methods}

\subsection{Database}

The Mexican Health and Ageing Study (MHAS) (ENASEM is the acronym in Spanish) is a longitudinal study involving a home-based and nationally representative sample of older adults born in Mexico in 1951 or earlier. The sample was drawn using multistage probabilistic sampling procedures. The National Employment Survey (ENE) was the sampling frame. Participants constituting a stratified sample representative of the national population were first interviewed in 2001 (response rate of 92\%), with follow-ups in 2003 (response rate of 93\%), 2012 (response rate of $88 \%$ ) and 2015 (response rate of $88.3 \%$ ). The database provides detailed sociodemographic characteristics and information about health conditions such as limitations in basic Activities of Daily Living (ADLs) and Instrumental Activities of Daily Living (IADLs), depression, and mobility $^{41-44}$. For more information about the MHAS study we refer to Wong, Michaels-Obregón, and Palloni ${ }^{45}$ and the Instituto Nacional de Estadística y Geografía ${ }^{46}$. This (The MHAS) study was approved by the Institutional Review Boards or Ethics Committees of the University of Texas Medical Branch in the United States, the Instituto Nacional de Estadística y Geografía (INEGI) and the Instituto Nacional de Salud Pública (INSP) in Mexico. Data files and documentation are public and available at www.mhasweb.org.

Our sample is based on 15,186 respondents at baseline. Inclusion criteria were: (i) being 50 years and over at baseline, and (ii) having been directly interviewed. We excluded dropouts (by death or failure to follow up), and individuals without complete data for mobility, information 
about non-communicable diseases (NCD) and self-rated health. The final sample included 5,169 respondents (Figure 1).

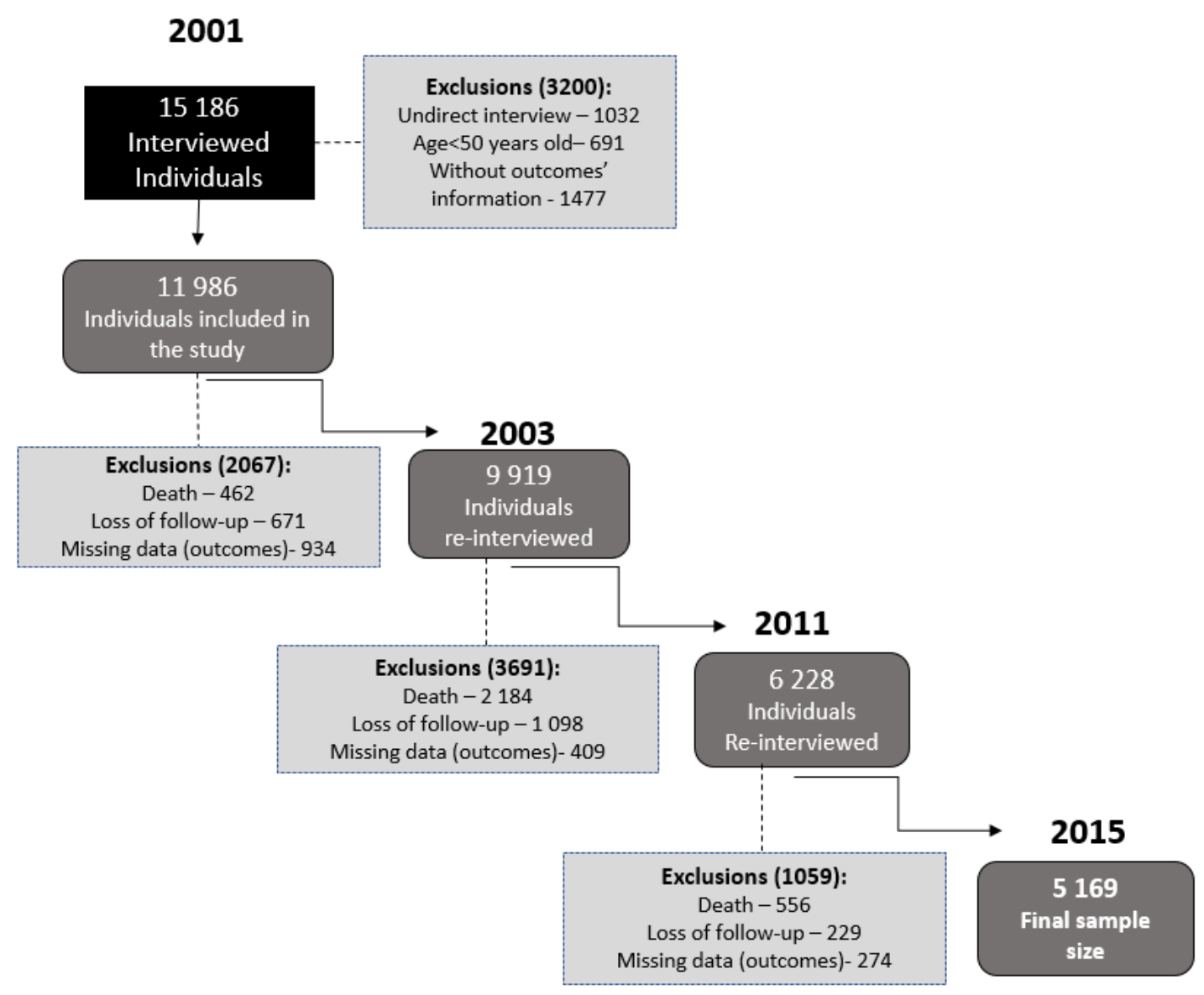

Figure 1. Study sample size across waves.

\subsection{Measures}

Box 1 presents all variables, their meanings and respective operationalisations.

Outcomes. Three outcomes were considered. The mobility outcome was computed based on questions (binary answers) indicating if the respondent had difficulty to perform any of the eight activities displayed in Table 1. Responses "cannot do" or "does not do" were considered 
missing values (without response). Each dichotomized indicator was added to generate a sum score $(0-8)$. This process was repeated across waves. The number of NCD (range 0-5) was calculated in a similar fashion. Self-rated health was evaluated as a score (1-5).

Past, intermediate and current SEP indicators. In the ENE survey, six categorical SEP indicators were available relating to three life stages of the respondents: childhood, adolescence and contemporaneous. These indicators covered distinct aspects of socio-economic exposure to adversity, educational level and (self-rated) economic condition.

Additional Covariates. Information on sex, marital status, and cognitive function were retireved. Cognitive function was evaluated using the Cross-Cultural Cognitive Examination ${ }^{47,48}$. This is a sensitive cognitive screening instrument for dementia and cognitive impairment in older adult populations, which takes into account cultural, linguistic and educational factors. Five domains were evaluated (verbal learning, verbal memory, visual construction, visual memory and attention) and the sum of scores varied between zero and 80; the higher the score, the better the cognitive function. This variable was categorized into tertiles. 
Box 1. Measures and variables used in the study, valid responses and waves.

\begin{tabular}{|c|c|c|}
\hline Definition & Question & Valid response options \\
\hline \multicolumn{3}{|c|}{ Multivariate Outcomes } \\
\hline \multicolumn{3}{|l|}{ Mobility } \\
\hline $\begin{array}{l}\text { About the last three months, } \\
\text { because of a health } \\
\text { problem... }\end{array}$ & $\begin{array}{l}\text { Do you have difficulty with running or jogging several } \\
\text { blocks? } \\
\text { Do you have difficulty with walking several blocks? } \\
\text { Do you have difficulty with walking one block? } \\
\text { Do you have difficulty with getting up from a chair } \\
\text { after sitting for long periods? } \\
\text { Do you have difficulty with climbing several flights of } \\
\text { stairs without resting? } \\
\text { Do you have difficulty with climbing one flight of } \\
\text { stairs without resting? } \\
\text { Do you have difficulty with stooping, kneeling or } \\
\text { crouching? } \\
\text { Do you have difficulty with extending the arms above } \\
\text { shoulder level? }\end{array}$ & $\begin{array}{l}\text { yes/no } \\
\text { yes/no } \\
\text { yes/no } \\
\text { yes/no } \\
\text { yes/no } \\
\text { yes/no } \\
\text { yes/no } \\
\text { yes/no }\end{array}$ \\
\hline Final variable - Mobility & $\begin{array}{l}\text { Each dichotomic variable about mobility was summed, } \\
\text { for each wave, generating a score were } 0 \text { means "none } \\
\text { mobility dificulty" and the gradual increament } \\
\text { represents the number of activities that the individual } \\
\text { has difficulty in executing. }\end{array}$ & Score -0 to 8 \\
\hline \multicolumn{3}{|c|}{ Non-Communicable Diseases (self-reported information) } \\
\hline & $\begin{array}{l}\text { Has a doctor or medical perssonel ever told you that } \\
\text { you have Hypertesion? } \\
\text { Has a doctor or medical perssonel ever told you that } \\
\text { you have Diabetes? } \\
\text { Has a doctor or medical perssonel ever told you that } \\
\text { you have Depression? } \\
\text { Has a doctor or medical perssonel ever told you that } \\
\text { you have a stroke? } \\
\text { Has a doctor or medical perssonel ever told you that } \\
\text { you have arthritis or rheumatism? }\end{array}$ & $\begin{array}{l}\text { yes/no } \\
\text { yes/no } \\
\text { yes/no } \\
\text { yes/no } \\
\text { yes/no }\end{array}$ \\
\hline $\begin{array}{l}\text { Final variable - Number of } \\
\text { non-communicable diseases } \\
\text { (NCD) }\end{array}$ & $\begin{array}{l}\text { Each dichotomic variable about specific NCD was } \\
\text { summed, for each wave, generating a score were } 0 \\
\text { means "none NCD" and the gradual increament } \\
\text { represents the number of health condition that the } \\
\text { individual refered. }\end{array}$ & Score -0 to 5 \\
\hline \multicolumn{3}{|l|}{ Self-Rated Health } \\
\hline$($ Score -1 to 5$)$ & Would you say your health is... & $\begin{array}{l}\text { Excellent } \\
\text { Very good } \\
\text { Good } \\
\text { Fair } \\
\text { Poor }\end{array}$ \\
\hline
\end{tabular}


Box 1. Measures and variables used in the study, valid responses and waves (Continuation)

\begin{tabular}{|c|c|c|}
\hline Definition & Question & Valid response options \\
\hline \multicolumn{3}{|c|}{ Latent Class Analysis Components: Early, Intermediary and Current Socio-Economic Situation (SES) } \\
\hline \multicolumn{3}{|c|}{ Early socioeconomic situation: binary indicators } \\
\hline Lived in rural zone & $\begin{array}{l}\text { When you were living with your parents, your } \\
\text { residence was in }\end{array}$ & $\begin{array}{l}\text { a rural area } \\
\text { an urban area }\end{array}$ \\
\hline House composition* & Did your residence have a toilet inside the house? & $\begin{array}{l}\text { No } \\
\text { Yes }\end{array}$ \\
\hline Infant working* & $\begin{array}{l}\text { Did you or any of your brothers/sisters have to drop } \\
\text { out school to help your parents }\end{array}$ & $\begin{array}{l}\text { No } \\
\text { Yes }\end{array}$ \\
\hline Food security* & Did you generally go to bed hungry? & $\begin{array}{l}\text { No } \\
\text { Yes }\end{array}$ \\
\hline \multicolumn{3}{|c|}{ Intermediary SES: Years of formal education } \\
\hline & $\begin{array}{l}\text { Grade of education (discrete - categorized for the } \\
\text { study proposal) }\end{array}$ & $\begin{array}{l}\text { None } \\
1 \text { - } 6 \text { years } \\
7 \text { years or more }\end{array}$ \\
\hline \multicolumn{3}{|c|}{ Current SES: Self-rated economic situation in the baseline (2001) } \\
\hline & Would you say your financial situation is & $\begin{array}{l}\text { Excellent/Very good/ Good } \\
\text { Fair/ Poor }\end{array}$ \\
\hline \multicolumn{3}{|c|}{ Additional sociodemographic and health characteristics covariates (baseline) } \\
\hline Sex & & $\begin{array}{l}\text { Male } \\
\text { Female }\end{array}$ \\
\hline Age & $\begin{array}{l}\text { How old are you in full years? (categorized for the } \\
\text { study proposal) }\end{array}$ & $\begin{array}{l}50-59 \text { years } \\
60-69 \text { years } \\
70 \text { years and over }\end{array}$ \\
\hline Marital status & $\begin{array}{l}\text { What is your marital status? } \\
\text { We divided individuals in two groups, to facilitate an }\end{array}$ & $\begin{array}{l}\text { With a partner } \\
\text { s Without a partneer }\end{array}$ \\
\hline Cognitive Function & Cross-Cultural Cognitive Examination & Classified in tercile \\
\hline
\end{tabular}

*Questions about childhood - considering before the individual were 10 years old

\subsection{Statistical Analyses}

Analysis plan

Latent Class Analysis (LCA) and GBTM are unsupervised, model-based clustering techniques. The former addresses heterogeneity of answers to categorical questions by grouping subjects displaying similar scoring patterns ${ }^{49-51}$, whereas the latter is applied for the recognition and visualization of different patterns of temporal change, e.g. typical or atypical courses of 
development of one or multiple outcomes ${ }^{52}$. A conceptual account of both models, as well as the technical details of model fitting are provided as a supplement (Appendix 1). We used LCA to empirically derive distinct life-course SEP classes based on the respondents' answers to indicators of childhood, adolescence and contemporaneous socioeconomic situations. Multivariate GroupBased Trajectory Model $^{52}$ was applied to obtain data-driven, temporally dynamic classes of multivariate ageing, which were based on mobility, NCD and self-rated health

Models selection - Latent Class analysis (LCA) and Group-Based Trajectory Model (GBTM)

Model fitting for both methodologies is iterative, and model selection is customarily based on statistical model-fit criteria, e.g. Akaike Information Criterion (AIC), Bayesian Information Criterion (BIC) and entropy. Interpretability of extracted classes and their visual distinctiveness also play a decisive role in the selection of the final models (for both LCA and GBTM). Once the final (GBTM and LCA) model is selected, post hoc posterior probabilities of class-membership are estimated for each individual, who are then assigned to the class for which they had the highest posterior probability of assignment (PPA) - modal assignment ${ }^{52,53}$. Table S1 (Appendix 2), in the supplemental material, shows the model fit criteria used to guide the choice of the final number of classes in LCA, whereas Appendix 3 shows similar technical elements of the GBTM's classenumeration.

\section{Profiling of LCA and GBTM latent classes - Unadjusted Analysis}

Life course SEP classes and ageing trajectories were compared to several demographic and clinical variables. ANOVA and Chi-square tests were used for continuous and categorical variables, respectively. Unadjusted comparisons are presented in table format as supplemental material (Appendix 4 and 5) 
Linking life course SEP and Ageing trajectories - Adjusted Multinomial Logistic Regression

Posterior probabilities of class membership were estimated for all subjects for LCA and GBTM. For both models, each individual can be seen as a fractional member of the extracted classes. Because modal class-assignment disregards the probabilistic nature of class-membership, inferences with the latent constructs are known to be biased ${ }^{54}$. Given the two sources of errorprone modal assignments in our study (LCA and GBTM), this problem is expected to be exacerbated. For this reason, a few ad hoc strategies were applied to incorporate classification uncertainty while deriving the multinomial logistic regression model. First, the main independent variables were not the life-course SEP groups themselves, but rather the subjects' SEP classmembership probabilities (LCA-PPAs). Second, although the modally assigned multivariate trajectories constituted the (polytomous) dependent variable, GBTM's estimated posterior probabilities were used as case-weights in the multinomial regression model to account for the uncertainty in individual-level trajectory membership ${ }^{55}$.

\section{Sensitivity Analysis}

Attrition. To warrant adequate classification accuracy of the GBTM, analyses were based on subjects with complete data for the three longitudinal outcomes, which can potentially introduce a threat to external validity and attrition bias. We evaluated which baseline variables were independently linked to attrition, fitting a multiple logistic regression model on the whole sample (Appendix 5). Results of all sensitivity analyses are provided in the appendices. They are summarized in the results section and their implications addressed in the discussion. 
Statistical analyses were conducted using Stata version 15.1 (StataCorp, College Station, TX) and SAS version X.X (SAS Institute, Cary, NC). Trajectory graphics and Forest plots were made using the package ggplot2 from $\mathrm{R}$ version 3.5.2.

\section{Results}

\section{Life course SEP - Latent Class Analysis}

Increasing the number of latent classes provided a marginally better fit to the data (TS1). However, with more than 6 classes, the size of the classes became prohibitively small, and heterogeneity of the latent profiles was not improved. Thus, a model with 6 latent classes was selected. 


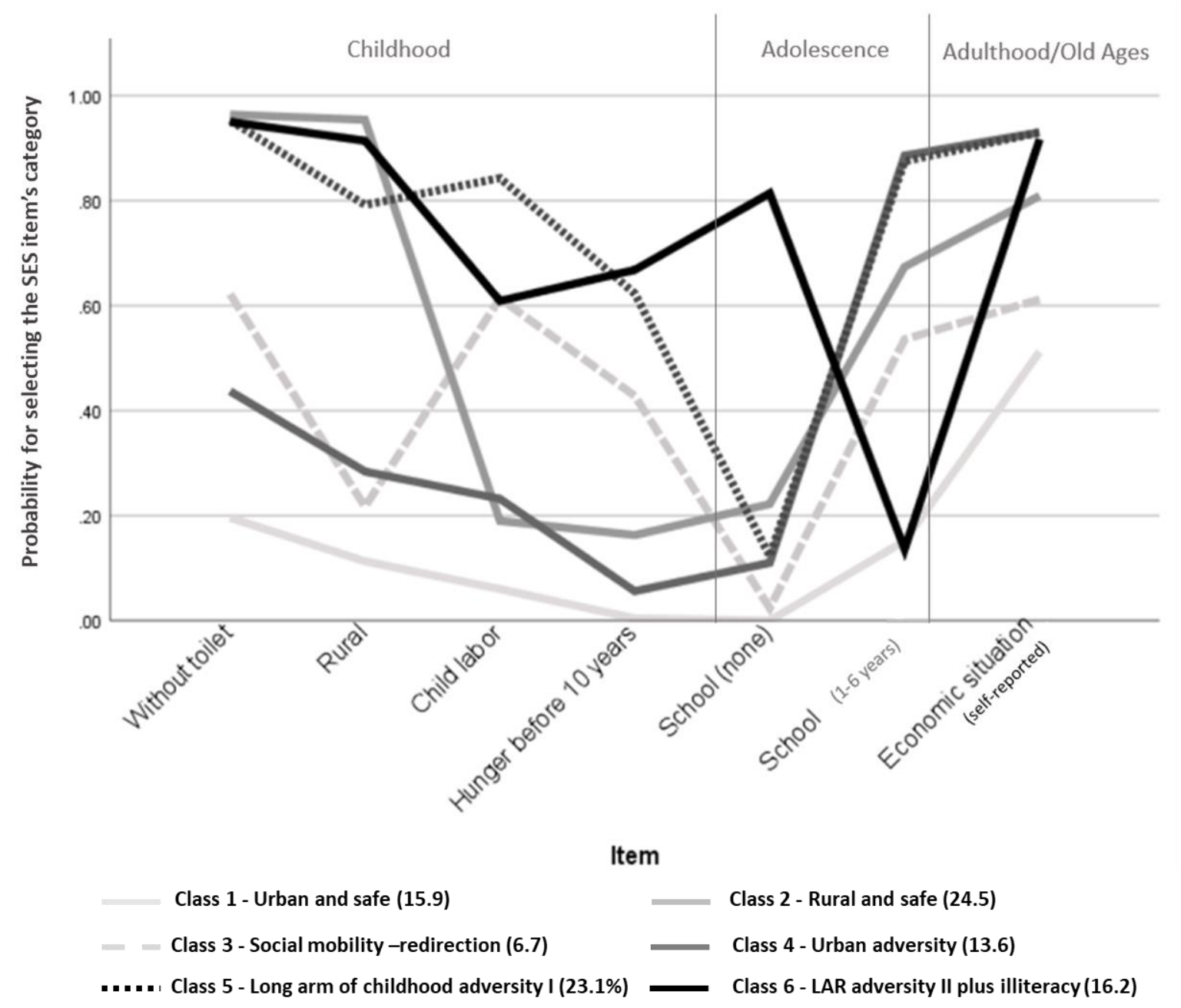

Figure 2. Profile probability plot illustrating six subgroups (with estimated sizes) identified from the responses to the SES items. The y-axis captures the probability of selecting the provided answer category (x-axis).

Figure 2 shows the profile probability plot for the final LCA model (6 classes). On the yaxis is the probability for selecting the item's category displayed on the x-axis. For instance, for the question of whether the respondents (or their siblings) had to drop out of school to work as children - Child labor - the plot shows the probability of subjects answering 'yes' for each extracted class. 
A variable picture of life course SEP emerged, characterized by several cross-combinations among its indicators. The place of residence during childhood to some extent linked to the absence/presence of a toilet, which gave rise to a dichotomy with most respondents falling in either rural (classes 2, 5 and 6) or urban areas (1,3 and 4). For the other items, the separation was less clear-cut. A high probability of having suffered socioeconomic adversity in infancy, as measured by child labor and hunger, was characteristic of two rural classes (5 and 6). For them, the long arm of unfavorable childhood circumstances reached through adolescence into adulthood: a poor educational level and self-rated SEP afflicted both classes and in particular class 6, whose members were also illiterate. Notably, the largest class 2, also rural, deviated from this pernicious pattern of poverty. Although educational level and current SEP seemed only marginally better off than its counterparts (rural classes 5 and 6), members of class 2 were less exposed to childhood hardships. Urban class 1 had the most beneficial profile: characterized by safe childhood environment, highest educational attainment and contemporaneous self-rated financial situation. Curiously, respondents from the urban class 4 and rural class 5 , despite being indistinguishable in their response patterns for intermediary and current SEP questions, came from opposite childhood conditions, with the former seemingly having had a better start. Lastly, the smallest class 3 emerged as the odd one out. A substantial proportion of its members worked as children and experienced hunger but, along their life course, they seemed to have attained a better educational level (almost half had higher education) and the self-rated financial situation was only second-best to class 1 .

Based on these configurations, the life course SEP classes were termed:

Class 1: Urban and safe (15.9\%) 
Class 2: Rural and safe (24.5\%)

Class 3: Social mobility - redirection (6.7\%)

Class 4: Urban adversity (13.6\%)

Class 5: Long arm of childhood adversity I (23.1\%)

Class 6: Long arm of childhood adversity II plus illiteracy (16.2\%)

The life course SEP classes differed in several socio-demographic features (see Appendix 2). In a nutshell, the most advantageous classes, 1 and 3, had younger subjects, with 70.4 and 71.2 percent of adults between 50 and 59 years old in the baseline and a smaller prevalence of arthritis and pain. By contrast, the adversity classes $(4,5$ and 6$)$ were characterized by a higher proportion of older individuals with hypertension, diabetes and respiratory illness

\section{Multivariate Ageing Trajectories}

Model-fit statistical criteria plots ${ }^{53}$ are available in Appendix 3. A final number of 8 classes was selected to capture the underlying heterogeneity and which showed a good fit to the data.

Figures 3 (a to c) show the multivariate trajectory plots. Important: the color-coding maps the temporal linkages of the three outcomes where each color relates to ONE multivariate latent class. For instance, subjects assigned to the worst multi-trajectory (red) had at the outset poor mobility average scores which gradually deteriorated over the years; the highest average in NCD (which similarly worsened); and the highest average self-rated health (the higher the score the poorer the subjective evaluation of health), whose course suggests temporal stability, but this is possibly a manifestation of the scale's ceiling problem (all self-rated health trajectories have average values $>3$ ). On the other side of the joint developmental spectrum, subjects assigned to 
the dark green trajectory showed healthy and stable paths for all three outcomes, with self-rated health even improving at the end of the follow-up (more to that later). 

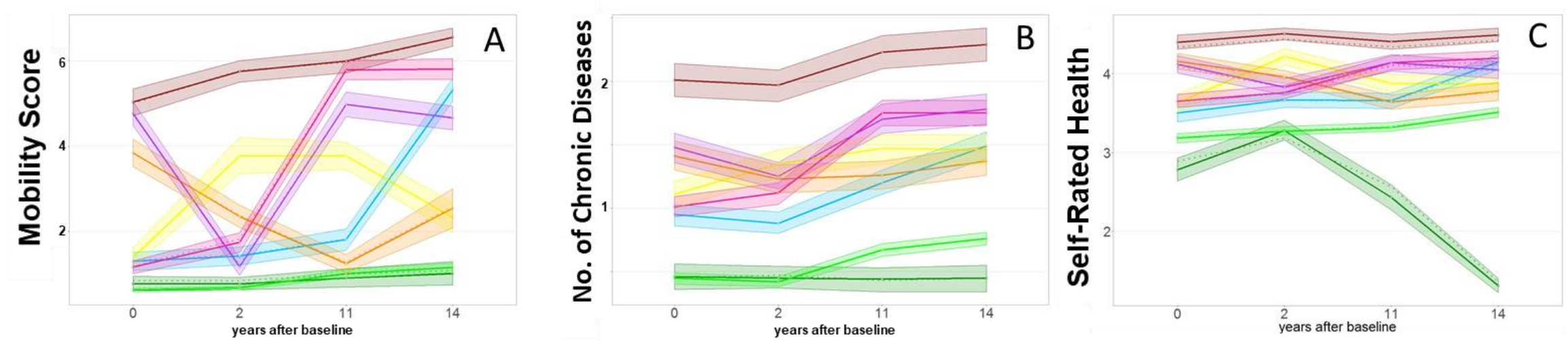

D
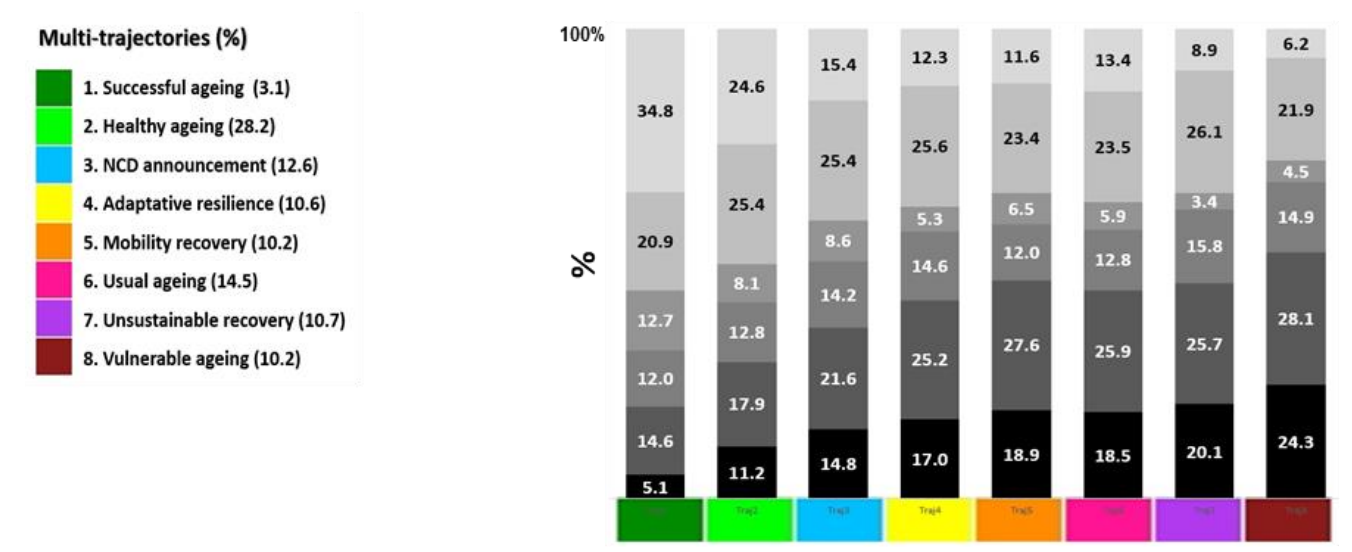

Trajectory groups

Figure 3. Latent multivariate ageing trajectories showing interdependencies among mobility (A), number of noncommunicable diseases (B) and self-rated health (C). Distribution (in relative frequency) of life course SES latent groups conditional in the multivariate trajectories of ageing (D). 
From all three outcomes mobility emerged as the most discriminatory, as evident in the little overlap among classes and a high level of heterogeneity in level and shape of temporal progressions. Except for two anomalies (orange and yellow, and to a lesser extent the purple trajectory), monotonicity characterized the loss of mobility in all remaining classes, reflecting functional decline in ageing, though at different rates and with distinct time-line locations of when their deterioration set-off. For NCD and self-rated health, by contrast, extracted trajectories were less distinguishable from each other (except for the two extreme ones). Despite the discriminatory upper hand of the mobility scale, the three outcomes behaved in lockstep fashion over time. This is apparent in the same rank ordering of the trajectories across the outcomes as well as in the mirror-reflection of their patterns of stability and change. Of note, the timing of upward deflections within the same multivariate trajectory was not always the same for the three dependent variables, e.g. in the blue trajectory 3 , an increase in NCD precedes and foreshadows the subsequent mobility decline (NCD announcement). An indication of similar temporal precedence is suggestive in trajectory 2 (Healthy ageing), with mobility scores still relatively stable, while a minor increase in the average NCS is detectable. Lastly, figure 1d shows the relative (crude) frequencies of the life course SEP classes conditional on the multivariate trajectories. A gradational picture emerged: the representation of adverse SEP classes increased steadily from the healthier to more vulnerable ageing trajectories, whereas an equally impressive decreasing gradient was observed for the most advantageous SEP, hinting, as expected, at an over-reaching impact of life course SEP on ageing (more to that later).

Ageing trajectories 1 (Successful ageing) and 2 (Healthy ageing)

The highly functional trajectory 1 was a very small group $(3.1 \%)$, for which the debilitating ageing process, e.g. loss of mobility, was not yet manifest. Its counterpart, the 
relatively healthy trajectory 2 and the largest in size (28.2\%), showed initial signs of deterioration in particular of NCD. Both trajectories were composed of a majority of men $(60.8$ and $60.4 \%$, respectively), and younger individuals (70.2\% and $72.5 \%$ between 50 and 59 years old in the baseline, respectively), with better cognitive function, lower prevalence of chronic diseases, pain and self-reported falls in the previous year, with baseline as reference (2001). Curiously, the most peculiar difference between trajectories 1 and 2, besides an indication of morbidity onset with an initial upward inflection of NCD trajectory for the latter, was self-rated health. The marked SRH improvement for trajectory 1 may possibly be an indication of the Uturn phenomenon: when adults after their fifties recapture their well-being which affects their self-perception of health ${ }^{56}$.

\section{Ageing trajectories 3 (NCD announcement) and 6 (Usual ageing)}

In both of these trajectories, a substantial decline in overall mobility was observed over the years which was accompanied by an increase in NCD and deterioration of self-rated health. Trajectory 6 had a marginally worse average course of 3 in all three outcomes. The main distinction between them was the location of the inflection point: trajectory 6's preceded 3's along the timeline. Important: their parallel mobility slopes should not be (mis)interpreted as equal paces of deterioration, since this occured for the latter over a period of 9 years (whether gradually or swiftly remains undetermined) and for the former over three years. Furthermore, the earlier point of inflection of NCD in trajectory 3 (blue), occurring before that of the mobility path, is suggestive of a mediation chain of events, i.e. he increase in the number of chronic diseases was accompanied by a lagged loss of mobility ${ }^{57}$. In general, these two trajectories had comparable profiles, with 6 being slightly worse-off: the proportion of females (59-60.4\%) and age composition ( $45.3 \%$ and $48.8 \%$ with 60 years or older at baseline) for trajectories 3 and 6 
respectively. Less than $30 \%$ of the sample presented cognitive classification in the best tertile and around $36 \%$ of them had hypertension.

Ageing trajectories 4 (adaptive resilience), 5 (mobility recovery) and 7 (unsustainable recovery)

These three trajectories showed some anomalies in the mobility temporal progressions. Trajectory 4, which had a good start in mobility and SRH, quickly deteriorated in both, thereafter marginally improving in SRH and, after some stable period, also improving in mobility. This led us to consider that its subjects were possibly more resilient in coping with the ageing process. The considerable improvement in mobility scores for both 5 and 7 , following a bad start, posed some interpretational challenges. However, the major recovery in mobility scores (second wave) in trajectory 7 was not sustained, as mobility average level returned to the value observed at baseline. Individuals assigned to trajectory 5 were at baseline younger (50-59: $65.3 \%$ ) than those assigned to trajectory 7 (35\% 74 years or more).

\section{Ageing trajectories 8 (vulnerable ageing)}

Making-up ca. $10 \%$ of the sample, older adults in the vulnerable ageing trajectory had the most disadvantageous profile: both in terms of the longitudinal paths with the worst onset values for all ageing outcomes, e.g. multimorbidity, accompanied by deterioration, as well as in their individual characteristics. The group was the oldest (70+: $12.8 \%)$, with a higher prevalence of women $(80.2 \%)$, the lowest cognitive score and highest prevalence of chronic conditions (63.1\% reports hypertension at baseline, $23.6 \%$, diabetes, and 45.6\%, arthritis) including self-reported falls in the previous years. They also lived without partners. Detailed results of demographic characteristics and ageing indicators are displayed in Appendix 4.

\section{Linking life course SEP and ageing trajectories - Multinomial logistic}


Figure 4 shows a forest plot with risk ratios (RRs) and 95\% CI conveying independent links between the life course SEP categories and the ageing trajectories. Reference groups for the interpretation of the RRs are given. To facilitate interpretation, consider for instance trajectory 2 (Healthy ageing). The point estimate RR for SEP 1 (PPA of life course SEP class 'urban and safe') compared to the reference group SEP 6 (PPA of life course SEP class 'the long arm rural adversity with illiteracy') was 10.51 . Hence, subjects assigned to the urban and safe life-course SEP 1 were 10.5 times more likely to age healthily (trajectory 2) than vulnerably (trajectory 8), once compared to subjects in the most adverse SEP class 6. Similarly, the chances for males to be assigned to all ageing trajectories (with vulnerable ageing, trajectory 8 , as reference) were substantially higher compared to females and followed an ordered pattern, with RRs decreasing from 7.33 in the trajectory 1 to 2.14 in trajectory 7 . The impact of cognitive levels on trajectories membership was inconclusive except for the successful ageing (trajectory 1) and mobility recovery (trajectory 5). Subjects with higher cognitive function were more likely to be assigned to these two trajectories. Finally, the overall gradient of the distribution of life course SEP conditional on the ageing trajectories (figure 3) was confirmed in the adjusted model. SEP gradational patterns were discernible within and between classes. In the former case, the RRs decreased bit by bit from SEP class 1 to 5 relative to the reference SEP 6 for all trajectories, except number 7, (unsustainable recovery), whereas comparisons of these graded patterns from trajectory 1 to 7 showed a steady decrease in RRs' magnitudes. 


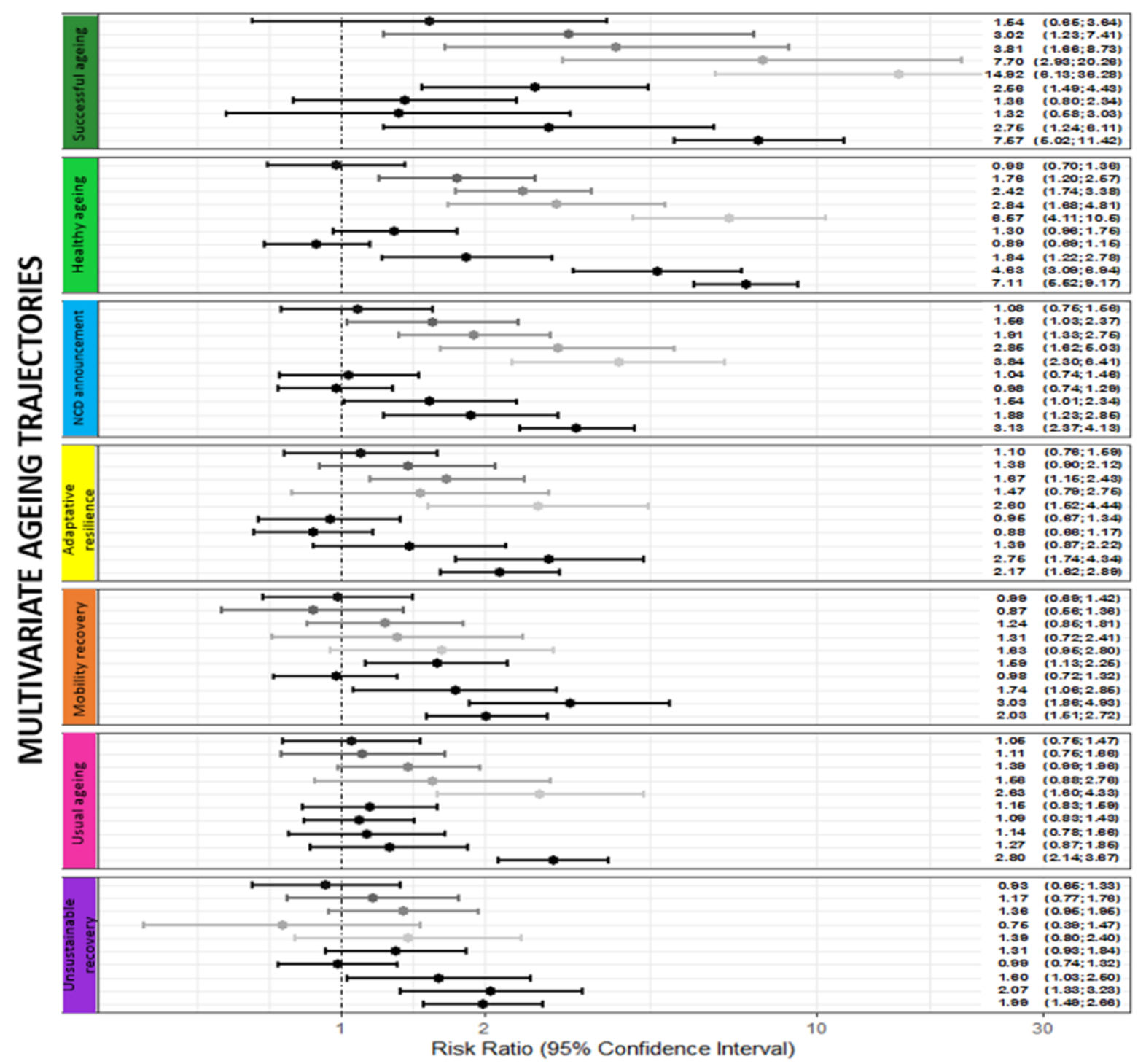

\section{Exposures}

$\begin{array}{ll}+ \text { Long arm of rural adversity } & + \text { Higher cognitive function } \\ + \text { Long arm of urban adversity } & + \text { Moderate cognitive function } \\ + \text { Rural and safe } & +60-69 \text { years old } \\ + \text { Social mobility } & +50-59 \text { years old } \\ + \text { Urban and safe } & + \text { Male }\end{array}$

Figure 4. Risk ratio and $95 \%$ confidence intervals for each multivariate ageing trajectory in reference to Vulnerable Ageing Trajectory (Traj 8 ) and respective factors associated, estimated by the multinomial regression model.

Note: The reference categories were "Long arm of rural adversity plus illiteracy" for Life course SES classes. The first tercile of cognitive evaluation was considerate the reference, as "Lower cognitive function". Oldest individuals (70 years or more in the baseline), and Female. 


\section{Discussion}

This study aimed for a temporal characterization of: 1 . socio-economic position across life and 2. multidimensional ageing in older adults. For this purpose, mixture modeling techniques were applied in two instances: LCA was used to unveil developmental SEP classes by clustering subjects with similar responses to SEP indicators of earlier and contemporaneous life; and GBTM was applied to uncover multivariate ageing trajectories based on longitudinal information of three health outcomes: functional mobility, morbidity (NCD) and self-rated health (SRD). In the ensuing lines we address important findings of each analysis and their individual merits, before tackling the insights obtained from linking the life course SEP classes and ageing trajectories.

\section{Life course SEP}

Life course scholars are increasingly grappling with the idea that the predictable patterned life course is eroding as both normative ideal and empirical reality

(Linda K George ${ }^{1}$ )

SEP, like ageing, is many-sided. Several measures are routinely used to quantify it: e.g. economic or material wealth (resources, income), education, occupation, social status, prestige and political power. All of them capture distinct nuances of SEP and are, thus, not directly interchangeable. They are, however, aliased to varying degrees, introducing confounding issues. Mutually adjusted regression models are routinely applied to correct for confounding, but as recently shown in the specific context of SEP, this approach underlies a common methodological problem known as the mutual-adjustment fallacy ${ }^{58}$. In brief, the interpretation

${ }^{1}$ Age structures, aging, and the life course. In K. Ferraro - Gerontology: Perspectives and issues. 2013 
of the regression coefficients of multiple SEP measures as unique 'independent effects' should be done with caution as they do not account for the shared information they provide. Moreover, the confounding and associated adjustment fallacy can be particularly difficult to handle when considering a life course perspective as SEP indices are knowingly entangled in mediation chains.

We circumvented this methodological trap by combining the available SEP indicators across a life span to empirically derive SEP typologies. This approach allowed for an unprecedented glimpse into variable pattern stability and change in socio-economic deprivations and adversity (or lack thereof) in Mexico. More than half of the sample (52.9\%) exhibited SEP developmental profiles well aligned to the tenet of the long arm of childhood (SEP classes 1, 5 and 6). For these subjects, social rigidity characterized their life-cycle transitions as either early advantages or disadvantages seemed to have persisted, accumulated and possibly compounded over time. The remaining classes deviated, in degree and kind, from this structurally constrained norm. Notably, residence in rural areas was not necessarily equated with childhood deprivation (class 2, rural and safe). Moreover, a start in urban areas, without any apparent sign of socio-economic adversity - based on the available indicators - was not translated into better educational attainment during adolescence and/or into adulthood opportunities (class 4, urban adversity). Importantly, although observed in a small proportion of subjects $(6.7 \%)$, the life course SEP category class 3 (redirection) hinted at upward social mobility. The members of this class were at higher risk of hunger and own (or sibling's') labor as infants. The SEP features of their later life stages, however, suggest that educational accomplishments may have attenuated the negative impact of abject childhood.

Summing up, SEP classes 1, 5 and 6, which were characterized by lifelong systemic trends of either poverty or wealth, provided evidentiary support for CA/DT. Class 3 (redirection) offered some indication for AAL, while the two remaining classes 2 and 4 (rural 
and safe, and urban adversity) did not strictly fit into any of the two conceptual models. Hence, the findings allowed not only for both life course theories to be accommodated (CA/DT and AAL), but also raised the possibility of other theoretical models being at play. One may consider that the deviant CA/DT classes 2,3 and to a lesser extent 4 , are possibly visible reminders of additional shapers of developmental history, herein not directly measured, e.g. life style and human agency.

One of the potential usefulness of mixture modeling techniques, as suggested by Hickendort et $\mathrm{al}^{59}$, is that they can help "identifying subgroups of individuals for whom different theories apply ... [therefore] it avoids the need to specify a single homogeneous theory for all individuals". Taken together, our findings make this line of thought rather cogent. That said, there are, to date, a few theoretical models that attempt to subsume distinct life course perspectives in a comprehensive manner, e.g. the Cumulative Inequality Theory $(\mathrm{CIT})^{60}$ and the life-course Canalization Framework ${ }^{61}$. Both of them center-stages the interplay between individual choices, resilience and human agency on the one hand, and distinct patterns of life long accumulation of resources, opportunities, constraints, on the other. CIT's proponents posit, among others, that advantages/disadvantages are not polar opposites of the same continuum, but rather distinct phenomena. In this light, CA/DT's framework becomes too restrictive in their basic tenet of cumulative advantage vs. disadvantage ${ }^{11}$. Instead, CIT gives prominence to patterns of accumulation which can vary in magnitude, onset and/or length, continuity or intermittency of exposures to advantages/disadvantages. Similarly, according to the life-course canalization framework ${ }^{61}$, the unfolding of individual paths in the life course landscape can be directed, or constrained, i.e. canalized by age-graded societal and institutional barriers. Individuals navigate their own developmental landscape, some with more agency/resilience than others, in such a way that the sequence of events along their paths also depends on the preceding states. 
Overall, our results endorses the idea gathering steam in epidemiological/ social sciences, that "there has been a shift from homogeneity, developmental continuity and universality of developmental processes, to heterogeneity, discontinuity and context specific development" ${ }^{62}$.

\section{Multivariate ageing trajectories}

"The most important characteristic of the aged is their diversity" (Joseph Quinn $\left.{ }^{2}\right)$

Clustering individuals by the changing dynamics of physical, clinical and subjective health parameters generated a developmental picture of their individual progressions and temporal linkages. For a minority of subjects (trajectory 1 - successful ageing), health decline was not yet manifest, with stability being the main feature of the outcomes' developmental paths (with exception of the SRH improvement). All other trajectories showed signs of deterioration, but differing in their starting levels, timing and paces of decline as well as patterns of co-evolution. Functional mobility (FM) emerged as the most discriminatory parameter. Nonetheless, the rank ordering of mobility onset values and timing of temporal changes were paralleled by those of the NCD and SRH. Time-lagged chains of co-occurrence were recognized for some classes: the onset of chronic disease preceded loss of functional mobility for trajectory 3,NCD announcement, and suggestively for trajectory 2 -healthy ageing. This observation lends support to the idea that (multi)morbidity predicts physical decline and loss of independence ${ }^{63}$, possibly mediating the association between pathophysiological processes and impaired physical function. The trajectories usual ageing (4)

2 Attitudes of professionals toward the aged In G. Maddox (Ed.), The Encyclopaedia of Aging. 1987. 
and adaptive resilience (3), however, deviated from this mediational picture. For them, temporal precedence could not be established, as only concurrency in patterns of NCD/FM change was detected. Failing to ascertain whether an increase in NCD came before mobility decline or vice-versa, or whether they happened simultaneously, may be attributable to the coarse granularity of the timeline. An alternative explanation is also feasible. The concurrency in developmental paths corroborates the hypothesis of a bi-directional association between multimorbidity and functional impairment ${ }^{63}$. This hypothesis contends that functional impairment and morbidity have common underlying causal processes, e.g. biological ageing, sharing similar risk factors and pathophysiological pathways. Therefore, instead of only a unidirectional mediating path, the link between morbidity and mobility could be further represented by feedback loops which capturie the entanglement of the two outcomes in a vicious circle of mutually exacerbating influences ${ }^{63}$.

All in all, the attained visual mapping engendered a better understanding of the coevolution of these three health outcomes in their nuanced and variable synchronicity.

SEP life course and ageing trajectories: A pervasive gradient

All particulars become meaningless if we lose sight of the pattern they jointly constitute $\left(\right.$ Karl Polanyi $\left.{ }^{3}\right)$

A mosaic constellation of SEP items across the life course yielded temporally dynamic typologies. These classes were non-linear, multidimensional and qualitatively different in their make-up. They did not constitute a uni-dimensional SEP continuum, but were, for the sake of convenience, gradably ordered to explore their links to ageing trajectories. The latter

\footnotetext{
${ }^{3}$ The Great Transformation: The Political and Economic Origins of Our Time. 1944.
} 
represented also heterogeneous, multivariate longitudinal profiles, debunking the perception of ageing as one-model-fits-all pattern of steady, progressive decline. They too were qualitatively ranked from successful to more vulnerable. Lastly, when linking the SEP and ageing constructs a conspicuous graded relationship surfaced: the risk for being assigned to better-off ageing trajectories, compared to the vulnerable one, decreased steadily from the most to less advantageous SEP classes, even after adjustment for known risk factors for senescence such as chronological age and sex. This graded pattern was not limited to the most successful ageing group (trajectory 1), but persisted across several ageing clusters, decreasing in magnitude (and statistical significance) from trajectory 1 (successful ageing) to trajectory 7 (unsustainable recovery) in a regular fashion.

An inverse gradient between socio-economic factors and health is not new, having been often and widely observed ${ }^{64}$. Moreover, like a dose-response association, a graded one hints at causality. Yet, despite the long-established SEP-health link, the mechanics of this causal relation are yet to be fully elucidated. Scope and space constraints preclude us from describing in details current mechanisms addressing the causal association ${ }^{65}$. Briefly, the Status Anxiety Hypothesis, for instance, suggests that the link between SEP and (premature) ageing is mediated by systemic inflammation resulted from chronic exposure to psycho-social stress ${ }^{66}$.

Our findings are, thus, an addition to the ever-increasing body of evidence for a SEPhealth relation, specifically for its inverse, graded nature. An intriguing feature of our results, however, is worth mentioning. In a separate analysis, many of the individual SEP indicators were independently linked to ageing trajectories membership (Appendix 6), but the graded association was to some extent diminished. It was only when combining the SEP information across distinct items (over a life course) that the gradational nature of this link was more discernable. The mutual-adjustment fallacy ${ }^{59}$ may underlie this discrepancy. At the same time, the emergence of a patterned gradient for the integrated SEP classes loosely evokes the 
Complexity Theory ${ }^{67}$. According to it, complex systems cannot be reduced to the sum of their constituent parts. Instead, they are a result of a large number of non-linearly, continuously interacting components. Complex systems" "emerging properties depend more on the interdependency of the elements than on the behavior of individual components ${ }^{\prime 67}$, generating spatially and temporally coordinated patterns of collective behaviors/factors ${ }^{68}$.

The 'complex system' interpretation, though academic is not farfetched. The association between health outcomes and socio-economic determinants is known to be dynamic and interactive $e^{69}$, reflecting long and intricate interplay between adaptable and modifiable life styles, individual choices, structurally generated constraints and epigenetic mechanisms. For this reason, researchers are becoming increasingly aware of the limitations of traditional epidemiological models of causality to study population health and complex diseases, which is why the need for adopting a complex systems approach has been advocated ${ }^{70}$. The results of all sub-analyses, from the unveiled heterogeneity of both life course SEP and ageing profiles to the regularity of the graded association, lend credence to this, to date, yet fringe movement.

\section{Limitations}

Retrospective data, dating back more than 40 years, are inescapably affected by recall bias. To minimize it, we used information only from questions asked at baseline (2001), avoiding those of later waves, which may be more prone to recollection slips. Furthermore, the analytical sample entailed only individuals with complete longitudinal data. The exclusion of subjects lost to follow-up (66\% of the original survey sample) introduced attrition bias, as well as posing a threat to the study's external validity. Results of the sensitivity analyses indicated that male, individuals 60 years and older at baseline, with lower cognitive function, more chronic conditions and reporting pain were linked to drop-out (Appendix 5). Additionally, 
childhood indicators and educational level were also related to attrition during the follow-up. Attrition was, thus, likely affected by socioeconomic forces. Still, a larger dropout rate for subjects socio-economically more vulnerable was not enough to dilute the SEP impact on the developmental paths of the measured individuals.

Lastly, readers should refrain from reifying the latent subgroups, as they do not represent true entities, but rather longitudinal features of the data.

\section{Final Remarks}

The applied SEP indices, health outcomes and the time scale were limited in their numbers and reach. Ageing, in its totality, remains imponderable. Nonetheless, in combination, these coarse variables reinforce the notion that highways to older ages can be diverse and intricate. For some, the paths were characterized by a gradual slide-down, for others by a much steeper descent, with a few turns, some twists. For most of them, though, the developmental courses were still fraught with unsurmountable obstacles.

Ferraro $^{71}$ claimed that the concept of modifiability of ageing processes is directly linked to the heterogeneity of populations, this latter being the primary evidence that ageing developmental paths can be deliberately altered via actionable interventions. In this light, the unveiled functioning/mobility trajectories and their tandem evolution with NCD and self-rated health provide evidentiary support for directing social policies to habitation, social security and transportation. Policies should foster mobility freedom and practice of physical activities of the older population, promoting healthy environment in cities and communities, with special attention to deprived zones. Examples of how this could be attained are numerous: the presence of sidewalks suitable for walkability, age-friendly traffic parameters, free public transportation and secure neighborhoods $\mathrm{s}^{72,73}$. In this regard, a lot has been done in Mexico in the last years ${ }^{36}$, 
but policies could be improved to benefit specific groups, e.g. individuals in socioeconomic disadvantage as predicted by The Action Plan for Ageing Attention/Care (Programa de Accion Atencion al Envejecimiento ${ }^{74}$. This Government strategy also included theoretical concepts of heterogeneity on ageing process.

The stretch of unfavorable SEP throughout life and its marked link to worse-off ageing profiles hint at the rigidity of the Mexican 'institutionalized path dependencies ${ }^{36}$. Disadvantageous initial SEP conditions, which may persist and accumulate over time, may imprint individuals in such a way as to curtail their life chances and compensatory agency to overcome societal constraints. Alas, public policies aimed at reducing social inequalities remain a challenge for Latin American countries, making it difficult to break the vicious cycle of poverty perpetuation/accumulation across a life time ${ }^{75}$.

\section{References}

1. Pruchno R. Successful aging: contentious past, productive future. Gerontologist. 2015;55(1):1-4. doi:10.1093/geront/gnv002.

2. Rowe JW, Kahn RL. Successful Aging. Gerontologist. 1997;37(4):433-440. doi:10.1093/geront/37.4.433.

3. Wolfson C. A Life Course Approach to Healthy Ageing. Int J Epidemiol. 2016;45(4):dyw139. doi:10.1093/ije/dyw139.

4. Kuh D, Ben-Shlomo Y, Lynch J, Hallqvist J, Power C. Life course epidemiology. J Epidemiol Community Health. 2003;57(10):778-783. doi:10.1136/JECH.57.10.778.

5. Lu W, Pikhart H, Sacker A. Domains and Measurements of Healthy Aging in Epidemiological Studies: A Review. Gerontologist. 2018;0(0):1-17. doi:10.1093/geront/gny029.

6. Stowe JD, Cooney TM. Examining Rowe and Kahn's Concept of Successful Aging: Importance of Taking a Life Course Perspective. Gerontologist. 2015;55(1):43-50. doi:10.1093/geront/gnu055.

7. Strawbridge WJ, Wallhagen MI, Cohen RD. Successful aging and well-being: self-rated compared with Rowe and Kahn. Gerontologist. 2002;42(6):727-733.

8. Rowe JW, Kahn RL. Successful Aging 2.0: Conceptual Expansions for the 21st Century. J Gerontol B Psychol Sci Soc Sci. 2015;70(4):593-596. doi:10.1093/geronb/gbv025. 
9. Cosco TD, Stephan BCM, Muniz G, Brayne C, CC75C Study Collaboration. A Novel Examination of Successful Aging Trajectories at the End of Life. Can J Aging / La Rev Can du Vieil. 2016;35(4):533-540.

10. Crystal S, Shea D. Cumulative advantage, cumulative disadvantage, and inequality among elderly people. Gerontologist. 1990;30(4):437-443. http://www.ncbi.nlm.nih.gov/pubmed/2394380. Accessed September 7, 2018.

11. Dannefer D. Systemic and Reflexive: Foundations of Cumulative Dis/Advantage and Life-Course Processes. Journals Gerontol Ser B. 2018.

12. Ferraro KF, Farmer MM. Double jeopardy, aging as leveler, or persistent health inequality? A longitudinal analysis of white and black Americans. J Gerontol B Psychol Sci Soc Sci. 1996;51(6):S319-28. http://www.ncbi.nlm.nih.gov/pubmed/8931631. Accessed January 7, 2019.

13. Ferraro KF, Kelley-Moore JA. Cumulative Disadvantage and Health: Long-Term Consequences of Obesity? Am Sociol Rev. 2003;68(5):707-729. http://www.ncbi.nlm.nih.gov/pubmed/22581979. Accessed April 20, 2018.

14. Ben-Shlomo Y, Kuh D. A life course approach to chronic disease epidemiology: conceptual models, empirical challenges and interdisciplinary perspectives. Int $J$ Epidemiol. 2002;31(2):285-293. doi:10.1093/ije/31.2.285.

15. Kuh D, Karunananthan S, Bergman H, Cooper R. A life-course approach to healthy ageing: maintaining physical capability. Proc Nutr Soc. 2014;73(2):237-248. doi:10.1017/S0029665113003923.

16. Blane D, Webb E, Wahrendorf M, Netuveli G. Life course influences on quality of life at age 50 years: evidence from the National Child Development Study (1958 British birth cohort study). Longit Life Course Stud. 2012;3(3):346-358. doi:10.14301/llcs.v3i3.178.

17. Kendig H, Loh V, O'Loughlin K, Byles J, Nazroo JY. Pathways to Well-Being in Later Life: Socioeconomic and Health Determinants Across the Life Course of Australian Baby Boomers. J Popul Ageing. 2016;9(1-2):49-67. doi:10.1007/s12062-015-9132-0.

18. Stringhini S, Zaninotto P, Kumari M, Kivimäki M, Lassale C, Batty GD. Socioeconomic trajectories and cardiovascular disease mortality in older people: the English Longitudinal Study of Ageing. Int $J$ Epidemiol. 2018;47(1):36-46. doi:10.1093/ije/dyx106.

19. Liu L, Xue F, Ma J, Ma M, Long Y, Newschaffer CJ. Social position and chronic conditions across the life span and risk of stroke: a life course epidemiological analysis of 22,847 American adults in ages over 50. Int J Stroke. 2013;8 Suppl A100(0 100):5055. doi:10.1111/j.1747-4949.2012.00927.x.

20. de Mestral C, Stringhini S. Socioeconomic Status and Cardiovascular Disease: an Update. Curr Cardiol Rep. 2017;19:1-12. doi:10.1007/s11886-017-0917-z.

21. Ferrucci L, Cooper R, Shardell M, Simonsick EM, Schrack JA, Kuh D. Age-Related Change in Mobility: Perspectives From Life Course Epidemiology and Geroscience. 
Journals Gerontol Ser A Biol Sci Med Sci. 2016;71(9):1184-1194. doi:10.1093/gerona/glw043.

22. Zimmer Z, Bao L, Mayol NL, Chen F, Perez TLL, Duazo PL. Functional limitation trajectories and their determinants among women in the Philippines. Demogr Res. 2017;36:863-892. doi:10.4054/DemRes.2017.36.30.

23. Chiu C-J, Wray LA. Physical disability trajectories in older Americans with and without diabetes: the role of age, gender, race or ethnicity, and education. Gerontologist. 2011;51(1):51-63. doi:10.1093/geront/gnq069.

24. Díaz-Venegas C, Wong R. Trajectories of limitations in activities of daily living among older adults in Mexico, 2001-2012. Disabil Health J. 2016;9(3):524-532. doi:10.1016/j.dhjo.2016.01.011.

25. White DK, Neogi T, Nevitt MC, et al. Trajectories of Gait Speed Predict Mortality in Well-Functioning Older Adults: The Health, Aging and Body Composition Study. Journals Gerontol Ser A Biol Sci Med Sci. 2013;68(4):456-464. doi:10.1093/gerona/gls 197.

26. Angelini V, Howdon DDH, Mierau JO. Childhood Socioeconomic Status and LateAdulthood Mental Health: Results From the Survey on Health, Ageing and Retirement in Europe. Journals Gerontol Ser B. 2019;74(1):95-104. doi:10.1093/geronb/gby028.

27. Kuh D, Richards M, Cooper R, Hardy R, Ben-Shlomo Y. Life course epidemiology, ageing research, and maturing cohort studies: a dynamic combination for understanding healthy ageing. In: Kuh D, Richards M, Cooper R, Hardy R, Ben-Shlomo Y, eds. A Life Course Approach to Healthy Ageing. Oxford University Press; 2014:3-15.

28. Zimmer Z, Hanson HA, Smith K. Childhood socioeconomic status, adult socioeconomic status, and old-age health trajectories. Demogr Res. 2016;34:285-320. doi:10.4054/DemRes.2016.34.10.

29. Stringhini S, Zaninotto P, Kumari M, Kivimäki M, Lassale C, Batty GD. Socioeconomic trajectories and cardiovascular disease mortality in older people: the English Longitudinal Study of Ageing. Int $J$ Epidemiol. 2018;47(1):36-46. doi:10.1093/ije/dyx106.

30. Sacker A, Clarke P, Wiggins RD, Bartley M. Social dynamics of health inequalities: a growth curve analysis of aging and self assessed health in the British household panel survey 1991-2001. J Epidemiol Community Heal. 2005;59(6):495-501.

31. Kim J, Miech R. The Black-White difference in age trajectories of functional health over the life course. Soc Sci Med. 2009;68(4):717-725. doi:10.1016/J.SOCSCIMED.2008.12.021.

32. Dupre ME. Educational Differences in Age-Related Patterns of Disease: Reconsidering the Cumulative Disadvantage and Age-As-Leveler Hypotheses*. J Health Soc Behav. 2007;48:1-15. https://journals.sagepub.com/doi/pdf/10.1177/002214650704800101.

33. Pudrovska T, Anikputa B. Early-Life Socioeconomic Status and Mortality in Later Life: An Integration of Four Life-Course Mechanisms. Journals Gerontol Ser B. 
2014;69(3):451-460. doi:10.1093/geronb/gbt122.

34. Dupre ME. Educational differences in health risks and illness over the life course: a test of cumulative disadvantage theory. Soc Sci Res. 2008;37(4):1253-1266. http://www.ncbi.nlm.nih.gov/pubmed/19227701. Accessed September 7, 2018.

35. Xu X, Liang J, Bennett JM, Botoseneanu A, Allore HG. Socioeconomic Stratification and Multidimensional Health Trajectories: Evidence of Convergence in Later Old Age. Journals Gerontol Ser B Psychol Sci Soc Sci. 2015;70(4):661-671.

36. Torres JM, Rizzo S, Wong R. Lifetime Socioeconomic Status and Late-life Health Trajectories: Longitudinal Results From the Mexican Health and Aging Study. Journals Gerontol Ser B Psychol Sci Soc Sci. 2018;73(2):349-360. doi:10.1093/geronb/gbw048.

37. Kwon E, Park S. Heterogeneous Trajectories of Physical and Mental Health in Late Middle Age: Importance of Life-Course Socioeconomic Positions. Int J Environ Res Public Health. 2017;14(6). doi:10.3390/ijerph14060582.

38. Xu X, Liang J, Bennett JM, Botoseneanu A, Allore HG. Socioeconomic stratification and multidimensional health trajectories: Evidence of convergence in later old age. Journals Gerontol - Ser B Psychol Sci Soc Sci. 2015. doi:10.1093/geronb/gbu095.

39. Raab M, Fasang A, Hess M. Pathways to death: The co-occurrence of physical and mental health in the last years of life. Demogr Res. 2018;38:1619-1634. doi:10.4054/DemRes.2018.38.53.

40. Kok AAL, Aartsen MJ, Deeg DJH, Huisman M. Capturing the Diversity of Successful Aging: An Operational Definition Based on 16-Year Trajectories of Functioning. Gerontologist. 2017;57(2):240-251. doi:10.1093/geront/gnv127.

41. Mexican Health and Aging Study. Data Files and Documentation (Public Use): Wave 1: Mexican Health and Aging Study (MHAS). http://www.mhasweb.org. Published 2001.

42. Mexican Health and Aging Study. Data Files and Documentation (Public Use): Wave 2: Mexican Health and Aging Study (MHAS). http://www.whasweb.org. Published 2003.

43. Mexican Health and Aging Study. Data Files and Documentation (Public Use): Wave 3: Mexican Health and Aging Study (MHAS). http://www.mhasweb.org. Published 2012.

44. Mexican Health and Aging Study. Data Files and Documentation (Public Use): Wave 4: Mexican Health and Aging Study (MHAS). http://www.mhasweb.org. Published 2015.

45. Wong R, Michaels-Obregon A, Palloni A. Cohort Profile: The Mexican Health and Aging Study (MHAS). Int J Epidemiol. 2017;46(2):e2-e2. doi:10.1093/ije/dyu263.

46. Instituto Nacional de Estadistica y Geografia. Encuesta Nacional Sobre Salud Y Envejecimiento En México 2015 - ENASEM.; 2016. www.inegi.org.mx. Accessed August 17, 2018.

47. Glosser G, Wolfe N, Albert ML, et al. Cross-cultural cognitive examination: validation of a dementia screening instrument for neuroepidemiological research. J Am Geriatr Soc. 1993;41(9):931-939. http://www.ncbi.nlm.nih.gov/pubmed/8409180. Accessed 
August 30, 2018.

48. Mejía-Arango S, Wong R, Michaels-Obregón A. Normative and standardized data for cognitive measures in the Mexican Health and Aging Study. Salud Publica Mex. 2015;57 Suppl 1:S90-6. http://www.ncbi.nlm.nih.gov/pubmed/26172239.

49. Lanza ST, Rhoades BL. Latent class analysis: an alternative perspective on subgroup analysis in prevention and treatment. Prev Sci. 2013;14(2):157-168. doi:10.1007/s11121-011-0201-1.

50. Kongsted A, Hestbæk L, Kent P. How can latent trajectories of back pain be translated into defined subgroups? BMC Musculoskelet Disord. 2017;18(1):285. doi:10.1186/s12891-017-1644-8.

51. Porcu M, Giambona F. Introduction to Latent Class Analysis With Applications. J Early Adolesc. 2017;37(1):129-158. doi:10.1177/0272431616648452.

52. Nagin DS, Jones BL, Lima Passos V, Tremblay RE. Group-based multi-trajectory modeling. Stat Methods Med Res. 2018;27(7):2015-2023. doi:10.1177/0962280216673085.

53. Klijn SL, Weijenberg MP, Lemmens P, van den Brandt PA, Lima Passos V. Introducing the fit-criteria assessment plot - A visualisation tool to assist class enumeration in groupbased trajectory modelling. Stat Methods Med Res. 2017;26(5):2424-2436. doi:10.1177/0962280215598665.

54. Nylund-Gibson K, Grimm RP, Masyn KE. Prediction from Latent Classes: A Demonstration of Different Approaches to Include Distal Outcomes in Mixture Models. Struct Equ Model A Multidiscip J. 2019;0:1-19.

55. Kamata A, Kara Y, Patarapichayatham C, Lan P. Evaluation of Analysis Approaches for Latent Class Analysis with Auxiliary Linear Growth Model. Front Psychol. 2018;9:130.

56. Stone AA, Schwartz JE, Broderick JE, Deaton A. A snapshot of the age distribution of psychological well-being in the United States. Proc Natl Acad Sci. 2010;107(22):99859990.

57. WHO. WHO | World Report on Ageing and Health 2015. World Health Organization; 2015. https://www.who.int/ageing/events/world-report-2015-launch/en/.

58. Green MJ, Popham F. Interpreting mutual adjustment for multiple indicators of socioeconomic position without committing mutual adjustment fallacies. BMC Public Health. 2019;19(1):10.

59. Hickendorf M, Edelsbrunner PA, Schneider M, Trezise K. Informative tools for characterizing individual differences in learning: Latent class, latent profile, and latent transition analysis. Learn Individ Differ. 2018;66:4-15.

60. Ferraro K, Morton P. What Do We Mean by Accumulation? Advancing Conceptual Precision for a Core Idea in Gerontology. Journals Gerontol Ser B Psychol Sci Soc Sci. 2016; 73(2):269-278. 
61. Heckhausen J, Buchmann M. A multi-disciplinary model of life-course canalization and agency. Adv Life Course Res. 2019;41:100246.

62. Heikkinen E. A life course approach: research orientations and future challenges. Eur Rev Aging Phys Act. 2011;8(1):7-12.

63. Calderón-Larrañaga A, Vetrano DL, Ferrucci L, et al. Multimorbidity and functional impairment-bidirectional interplay, synergistic effects and common pathways. $J$ Intern Med. 2019;285(3):255-271.

64. Braveman P, Gottlieb L. The social determinants of health: it's time to consider the causes of the causes. Public Health Rep. 2014;129 Suppl 2(Suppl 2):19-31.

65. McCrory C, McLoughlin S, O'Halloran AM. Socio-Economic Position Under the Microscope: Getting "Under the Skin" and into the Cells. Curr Epidemiol Reports. 2019:1-9.

66. Layte R, McCrory C, Cheallaigh CN, et al. A Comparative Analysis of the Status Anxiety Hypothesis of Socio-economic Inequalities in Health Based on 18,349 individuals in Four Countries and Five Cohort Studies. Sci Rep. 2019;9(1):796.

67. Turner JR, Baker RM. Complexity Theory: An Overview with Potential Applications for the Social Sciences. Systems. 2019;7(1):4.

68. Kelso JAS. Principles of dynamic pattern formation and change for a science of human behavior. In: Bergman LR, Cairns RB, Nilsson LG, Nystedt L, eds. Developmental Science and the Holistic Approach. Mahwah, NJ: Lawrence Erlbaum Associates Publishers; 2000:63-83.

69. Braveman P, Gottlieb L. The Social Determinants of Health: It's Time to Consider the Causes of the Causes. Public Health Rep. 2014;129(1_suppl2):19-31.

70. Maziak W. Is uncertainty in complex disease epidemiology resolvable? Emerg Themes Epidemiol. 2015;12(1):7.

71. Ferraro KF, Willmoth JM. The Gerontological Imagination. In: Gerontology: Perspectives and Issues. New York Springer; 2007:325-342.

72. Fitzgerald KG, Caro FG. An Overview of Age-Friendly Cities and Communities Around the World. J Aging Soc Policy. 2014;26(1-2):1-18. doi:10.1080/08959420.2014.860786.

73. Höfelmann DA, Roux AVD, Antunes JLF, Peres MA. Association of perceived neighborhood problems and census tract income with poor self-rated health in adults: a multilevel approach. Cad Saude Publica. 2015;31(suppl 1):79-91. doi:10.1590/0102311 X00210913.

74. Mexico. Secretaria de Salud. Centro Nacional de Vigilancia Epidemiologica. Programa de Accion: Atencion Al Envejecimiento. Secretaria de Salud; 2001.

75. Wong R, Palloni A. Aging in Mexico and Latin America. In: Uhlenberg P, ed. International Handbook of Population aging2. Dordrecht: Springer; 2009. 


\section{APPENDIX 1 - Description of Latent Class Analysis and Group Based trajectory Models}

\section{Latent Class Analysis (LCA) and Group Based Trajectory Model (GBTM)}

Latent Class Analysis. LCA is statistical technique increasingly used for research of social/health concepts, which are difficult to observe directly and are characterized of multiple facets, requiring measurement of multiple (categorical) variables ${ }^{1-4}$. LCA capitalizes on the heterogeneity of answers to several categorical variables, clustering subjects in non-directly observable sub-groups with similar responses patterns.

Multivariate Group Based Trajectory Model. GBTM clusters individuals sharing similar patterns of stability and change of outcome(s) over time (latent trajectories). The advantage of the multivariate version of $\mathrm{GBTM}^{4}$ is that, besides identifying individual trajectories of each outcome separately, it also describes their (distinct) patterns of joint evolution.

\section{Model Fitting for the retrospective (LCA) and prospective data (GBTM)}

For LCA, models with 2 up to 7 classes were fitted (Table S1). The model fitting for GBTM was more complex, involving several in-between steps. First, number of latent trajectories was established (class-enumeration) using a supportive R-code that compiles fitindices for several models with different number of latent classes (Fit-criteria Assessment Plots - F-CAP $)^{5}$. For this purpose, models with increasing numbers of classes were run (1 to 10), all of which with cubic polynomials. The resulting FCAPs are available in the appendix, as supplemental material (Appendix 3).

Briefly, FCAPs are automated graphs displaying how eight goodness-of-fit and modeladequacy criteria change as a function of increasing number of latent classes. Censored Normal was used as link function for mobility and self-rated health and Zero-inflated Poisson for number of non-communicable diseases. After class-enumeration, the order of the polynomials determining the trajectories' level and shape was established by pruning non-significant higher polynomials (higher p-values - e.g. 0.15- were occasionally accepted, once deletion of the higher orders deteriorated the BIC).

Longitudinal data without a natural starting point (e.g. birth) can be characterized by substantial onset variability. If this is, in turn, the dominating data feature, mixture models may underperform in their shape-detecting capabilities. As a result, data partitioning will be dominated by level, instead of shape, yielding flat, sparse, parallel trajectories, and process heterogeneity in the longitudinal data may go undetected. Fitting univariate GBTM to the mobility and SRH scores indicated that this was the case for both outcomes.

When level variability is the dominating data feature, Heggeseth et al. ${ }^{6}$ suggested removing level by subtracting the within-individual mean score from all within-individual observations. Our ad hoc strategy to circumvent the problem of sparse data partitioning involved, similarly, disentangling, as a first step, shape from the longitudinal data of an outcome variable by centering the scores. The vector of subject specific scores $\boldsymbol{Y}_{\boldsymbol{i}}$ were 
centered, i.e. the scores were subtracted from the individual's average over the time points ( $\overline{y_{\boldsymbol{t}}}=\boldsymbol{t}_{\boldsymbol{i}}^{-1} \sum_{t=\mathbf{1}}^{t_{i}} \boldsymbol{y}_{\boldsymbol{i}}$ ), previous to model fitting. Let $\boldsymbol{A}_{\boldsymbol{i}}=\boldsymbol{I}_{\boldsymbol{t}_{\boldsymbol{i}}}-\boldsymbol{t}_{\boldsymbol{i}}^{-\mathbf{1}} \mathbf{1}_{\boldsymbol{t}_{\boldsymbol{i}}} \mathbf{1}_{\boldsymbol{t}_{i}}^{T}$ be the centering matrix. The vector of centered scores for subject $i$ can be obtained by $\boldsymbol{C}_{\boldsymbol{i}}=\boldsymbol{A}_{\boldsymbol{i}} \boldsymbol{Y}_{\boldsymbol{i}}{ }^{6}$. We centered scores for both Mobility and Self-rated health. Different from Heggeseth et al. ${ }^{6}$, centered values were then coupled back to the original ones by using the multivariate version of GBTM. Thus, for both mobility and SRH the original and centered scores were amalgamated in the multivariate GBTM (for both the Censored Normal distribution was applied as link function), together with NCD scores. Model fitting proceeded as previously described.

1. Porcu M, Giambona F. Introduction to Latent Class Analysis With Applications. J Early Adolesc. 2017;37(1):129-158. doi:10.1177/0272431616648452.

2. Kamata A, Kara Y, Patarapichayatham C, Lan P. Evaluation of Analysis Approaches for Latent Class Analysis with Auxiliary Linear Growth Model. Front Psychol. 2018;9:130.

3. Nylund-Gibson K, Grimm RP, Masyn KE. Prediction from Latent Classes: A Demonstration of Different Approaches to Include Distal Outcomes in Mixture Models. Struct Equ Model A Multidiscip J. 2019;0:1-19.

4. Nagin DS, Jones BL, Lima Passos V, Tremblay RE. Group-based multi-trajectory modeling. Stat Methods Med Res. 2018;27(7):2015-2023. doi:10.1177/0962280216673085.

5. Klijn SL, Weijenberg MP, Lemmens P, van den Brandt PA, Lima Passos V. Introducing the fit-criteria assessment plot $-\mathrm{A}$ visualisation tool to assist class enumeration in groupbased trajectory modelling. Stat Methods Med Res. 2017;26(5):2424-2436. doi:10.1177/0962280215598665.

6. Heggeseth BC, Jewell NP. How Gaussian mixture models might miss detecting factors that impact growth patterns. Ann Appl Stat.2018; 12(1): 222-245. 
APPENDIX 2 - Fit-criteria for Latent Class Analysis

Table S1. Fit-criteria assessment indices of Latent Class Analysis.

\begin{tabular}{cccc}
\hline Group & AIC & BIC & Entropy \\
\hline 2 & 708.19 & 806.45 & 0.76 \\
3 & 590.55 & 760.86 & 0.67 \\
4 & 282.74 & 485.8 & 0.61 \\
5 & 191.69 & 447.16 & 0.60 \\
$\mathbf{6}$ & $\mathbf{1 6 5 . 2 6}$ & $\mathbf{4 7 3 . 1 3}$ & $\mathbf{0 . 5 7}$ \\
7 & 153.89 & 514.16 & 0.59 \\
\hline
\end{tabular}




\section{APPENDIX 3 - Fit-Criteria Assessment Plots - Group-Based Trajectory Models}

Fit-Criteria Assessment Plots
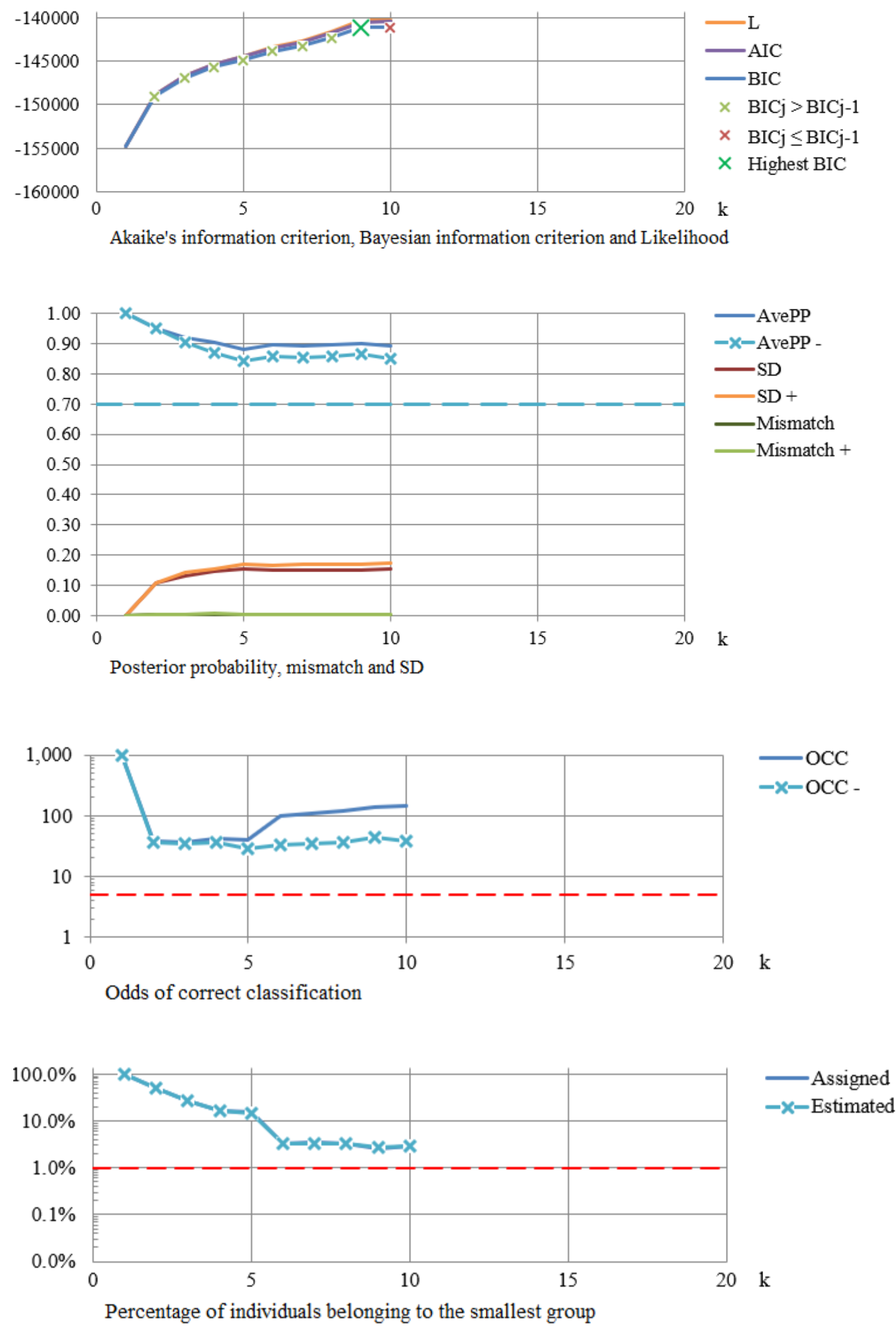
Table S3. Fit-criteria assessment indices for Multi-Trajectory Groups.

\begin{tabular}{cccccc}
\hline Group & $\begin{array}{c}\text { Average } \\
\text { PP* }\end{array}$ & Assigned & Estimated & AIC & BIC \\
\hline 2 & 0.95 & $38.69 \%$ & $48.83 \%$ & -148905.28 & -149052.7 \\
3 & 0.92 & $13.79 \%$ & $26.29 \%$ & -146763.53 & -146979.7 \\
4 & 0.90 & $11.24 \%$ & $16.06 \%$ & -145439.99 & -145724.9 \\
5 & 0.88 & $7.22 \%$ & $14.93 \%$ & -144523.57 & -144877.3 \\
6 & 0.89 & $1.00 \mathrm{E}-04$ & $3.21 \%$ & -143497.42 & -143919.9 \\
7 & 0.89 & $6.52 \%$ & $3.32 \%$ & -142813.25 & -143304.5 \\
$\mathbf{8}$ & $\mathbf{0 . 8 9}$ & $\mathbf{4 . 7 2 \%}$ & $\mathbf{3 . 1 9 \%}$ & $\mathbf{- 1 4 1 8 0 9 . 6 5}$ & $\mathbf{- 1 4 2 3 6 9 . 7}$ \\
9 & 0.90 & $4.80 \mathrm{E}-02$ & $2.72 \%$ & -140508.84 & -141137.7 \\
10 & 0.89 & $5.01 \mathrm{E}-02$ & $0.02 \%$ & -140457.66 & -141155.3 \\
$\mathbf{8} * *$ & $\mathbf{0 . 8 9}$ & $\mathbf{3 . 0 7 \%}$ & $\mathbf{3 . 0 7 \%}$ & $\mathbf{- 1 4 1 4 9 8 . 2 0}$ & $\mathbf{- 1 4 2 2 7 1}$ \\
\hline
\end{tabular}

*Average Posterior Probability of Assignment

**After polynomial order's refinement 
APPENDIX 4 - Distribution of Mexican older adults by life course Socioeconomic position profile.

Table S2. Life course SES classes profile.

\begin{tabular}{|c|c|c|c|c|c|c|c|c|c|c|c|c|c|c|c|}
\hline & \multicolumn{2}{|c|}{ Urban and safe } & \multicolumn{2}{|c|}{ Social mobility } & \multicolumn{2}{|c|}{ Rural and safe } & \multicolumn{2}{|c|}{ Long arm of urban } & \multicolumn{2}{|c|}{ Long arm of rural } & \multicolumn{2}{|c|}{ Long arm of rural } & \multicolumn{2}{|c|}{ Total } & \multirow{2}{*}{$p$ values } \\
\hline & $\mathbf{n}$ & $\%$ & $\mathrm{n}$ & $\%$ & $\mathbf{n}$ & $\%$ & $\mathbf{n}$ & $\%$ & $\mathbf{n}$ & $\%$ & $\mathbf{n}$ & $\%$ & $\mathbf{n}$ & $\%$ & \\
\hline Total & 824 & 15.9 & 344 & 6.7 & 1268 & 24.5 & 703 & 13.6 & 1192 & 23.1 & 838 & 16.2 & 5169 & 100 & \\
\hline \multicolumn{16}{|l|}{ Sex } \\
\hline Male & 365 & 44.3 & 157 & 45.6 & 513 & 40.5 & 252 & 35.9 & 574 & 48.2 & 322 & 38.4 & 2183 & 42.2 & $<0.001$ \\
\hline Female & 459 & 55.7 & 187 & 54.4 & 755 & 59.5 & 451 & 64.2 & 618 & 51.9 & 516 & 61.6 & 2984 & 57.8 & \\
\hline \multicolumn{16}{|l|}{ Age group } \\
\hline $50-59$ & 580 & 70.4 & 245 & 71.2 & 721 & 56.9 & 529 & 61 & 768 & 64.4 & 432 & 51.6 & 3175 & 61.4 & $<0.001$ \\
\hline $60-69$ & 209 & 25.4 & 90 & 26.2 & 437 & 34.5 & 240 & 34.1 & 354 & 29.7 & 293 & 35 & 1623 & 31.4 & \\
\hline 70 and over & 35 & 4.3 & 9 & 2.6 & 110 & 8.7 & 34 & 4.8 & 70 & 5.9 & 113 & 13.5 & 371 & 7.2 & \\
\hline \multicolumn{16}{|l|}{ Current marital status } \\
\hline In a relationship & 604 & 73.3 & 257 & 74.7 & 969 & 76.4 & 511 & 72.7 & 924 & 77.5 & 600 & 71.6 & 3865 & 74.8 & 0.018 \\
\hline Alone & 220 & 26.7 & 87 & 25.3 & 299 & 23.6 & 192 & 27.3 & 268 & 22.5 & 238 & 28.4 & 1304 & 25.2 & \\
\hline Year of education (mean) & 10.8 & (3.7) & 7.8 & (6.4) & 4 & $(4.4)$ & 4.1 & $(2.2)$ & 3.6 & (3.3) & 0.25 & (1.5) & 4.6 & $(4.8)$ & $<0.001$ \\
\hline \multicolumn{16}{|l|}{ Cognitive Function } \\
\hline 1st tercil & 77 & 9.3 & 70 & 20.4 & 479 & 37.8 & 200 & 28.5 & 402 & 33.7 & 561 & 67 & 1789 & 34.6 & $<0.001$ \\
\hline 2nd tercil & 184 & 22.3 & 103 & 29.9 & 454 & 35.8 & 266 & 37.8 & 490 & 41.1 & 206 & 24.6 & 1703 & 33 & \\
\hline 3rd tercil & 563 & 68.3 & 171 & 49.7 & 335 & 26.4 & 237 & 33.7 & 300 & 25.2 & 71 & 8.5 & 1677 & 32.4 & \\
\hline \multicolumn{16}{|l|}{ Hypertension } \\
\hline \multicolumn{16}{|l|}{ Diabetes } \\
\hline Yes & 73 & 9 & 33 & 9.8 & 117 & 9.6 & 84 & 12.1 & 145 & 12.4 & 89 & 11.1 & 541 & 10.8 & 0.089 \\
\hline \multicolumn{16}{|l|}{ Stroke } \\
\hline Yes & 5 & 0.6 & 3 & 0.9 & 21 & 1.7 & 12 & 1.7 & 21 & 1.8 & 18 & 2.2 & 80 & 1.6 & 0.126 \\
\hline \multicolumn{16}{|l|}{ Heart attack } \\
\hline Yes & 17 & 2.1 & 7 & 2.1 & 20 & 1.6 & 16 & 2.3 & 26 & 2.2 & 21 & 2.6 & 107 & 2.1 & 0.777 \\
\hline \multicolumn{16}{|l|}{ Respiratory illness } \\
\hline Yes & 39 & 4.8 & 14 & 4.2 & 56 & 4.6 & 40 & 5.8 & 78 & 6.7 & 58 & 7.2 & 90 & 1.8 & 0.051 \\
\hline \multicolumn{16}{|l|}{ Cancer } \\
\hline Yes & 21 & 2.6 & 6 & 1.8 & 12 & 1 & 8 & 1.2 & 24 & 2.1 & 19 & 2.4 & 90 & 1.8 & 0.051 \\
\hline \multicolumn{16}{|l|}{ Arthritis } \\
\hline Yes & 113 & 14 & 51 & 15.2 & 233 & 19.1 & 124 & 17.9 & 253 & 21.7 & 188 & 23.3 & 962 & 19.1 & $<0.001$ \\
\hline \multicolumn{16}{|l|}{ Pain } \\
\hline Yes & 227 & 27.6 & 111 & 32.4 & 493 & 38.9 & 310 & 44.1 & 536 & 45 & 419 & 49.8 & 2093 & 40.5 & $<0.001$ \\
\hline
\end{tabular}


APPENDIX 5 - Distribution of Mexican older adults by Multi-trajectory profile.

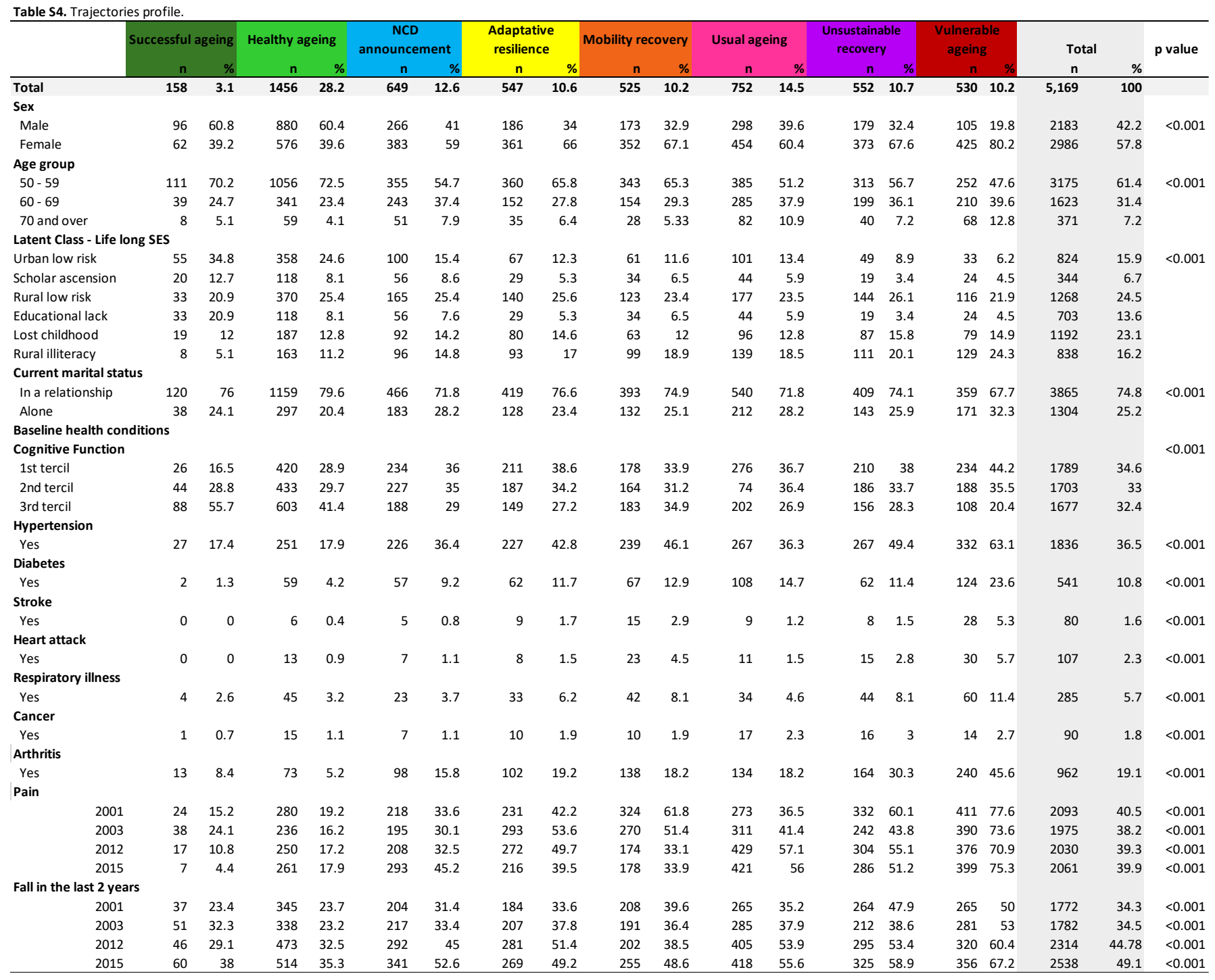




\section{APPENDIX 6 - Attrition Analysis}

TS 6. Distribution and logistic regression models to evaluate factors associated with attrition.

\begin{tabular}{|c|c|c|c|c|c|c|}
\hline & $\mathrm{n}$ & $\%$ & OR & $95 \% \mathrm{Cl}$ & OR(adj) & $95 \% \mathrm{Cl}$ \\
\hline Total & 13,595 & 100 & & & & \\
\hline \multicolumn{7}{|l|}{ Attrition } \\
\hline No & 5,169 & 33.4 & & & & \\
\hline Yes & 10,307 & 66.6 & & & & \\
\hline \multicolumn{7}{|l|}{ Sex } \\
\hline Male & 5,761 & 42.0 & Ref & & & \\
\hline Female & 7,879 & 58.0 & 1.01 & $0.94 ; 1.09$ & 0.72 & $0.66 ; 0.79$ \\
\hline \multicolumn{7}{|l|}{ Age group } \\
\hline $50-59$ & 5,683 & 47.4 & Ref & & & \\
\hline $60-69$ & 3,679 & 30.7 & 1.60 & $1.47 ; 1.74$ & 1.69 & $1.53 ; 1.87$ \\
\hline 70 and over & 2,624 & 21.9 & 7.69 & $6.81 ; 8.68$ & 7.28 & $6.33 ; 8.38$ \\
\hline \multicolumn{7}{|l|}{ Residencial area } \\
\hline Urban & 7,378 & 60.1 & Ref & & & \\
\hline Rural & 4,891 & 39.9 & 1.11 & $1.03 ; 1.19$ & 1.30 & $1.17 ; 1.44$ \\
\hline \multicolumn{7}{|l|}{ Toilet inside the house } \\
\hline Yes & 9,026 & 65.8 & Ref & & & \\
\hline No & 4,696 & 34.2 & 1.11 & $1.03 ; 1.19$ & 1.11 & $1.00 ; 1.24$ \\
\hline \multicolumn{7}{|l|}{ Dropout the school to work } \\
\hline No & 3,979 & 32.5 & Ref & & & \\
\hline Yes & 8,252 & 67.5 & 1.12 & $1.04 ; 1.20$ & 1.15 & $1.04 ; 1.26$ \\
\hline \multicolumn{7}{|c|}{ Hunger episode before 10 years old } \\
\hline No & 5,114 & 41.6 & Ref & & & \\
\hline Yes & 7,169 & 58.4 & 1.07 & $0.99 ; 1.16$ & & \\
\hline \multicolumn{7}{|l|}{ Level of education } \\
\hline None & 3,310 & 23.1 & 1.00 & $0.91 ; 1.11$ & 1.43 & $1.21 ; 1.69$ \\
\hline 1 - 6 years & 7,610 & 53.0 & 0.81 & $0.74 ; 0.88$ & 1.09 & $0.97 ; 1.23$ \\
\hline 7 years or more & 3,425 & 23.9 & Ref & & & \\
\hline \multicolumn{7}{|l|}{ Economic Situation } \\
\hline Excellent/ Very good/ Good & 11,139 & 79.1 & Ref & & & \\
\hline Fair/ Poor & 2,944 & 20.9 & 1.11 & $1.01 ; 1.20$ & & \\
\hline \multicolumn{7}{|l|}{ Baseline health conditions } \\
\hline \multicolumn{7}{|l|}{ Cognitive Function } \\
\hline 1st tercil & 4,904 & 34.7 & 1.54 & $1.41 ; 1.98$ & 1.74 & $1.52 ; 1.98$ \\
\hline 2nd tercil & 4,712 & 33.4 & 0.93 & $0.86 ; 1.01$ & 1.17 & $1.05 ; 1.32$ \\
\hline 3rd tercil & 4,513 & 31.9 & Ref & & & \\
\hline \multicolumn{7}{|c|}{ Number of non-communicable diseases } \\
\hline None & 4,480 & 33.1 & Ref & & & \\
\hline One & 4,572 & 33.8 & 1.09 & $1.00 ; 1.19$ & 1.14 & $1.02 ; 1.28$ \\
\hline Two & 2,993 & 22.1 & 1.3 & $1.18 ; 1.43$ & 1.39 & $1.22 ; 1.58$ \\
\hline Three & 1,237 & 9.1 & 1.51 & $1.32 ; 1.73$ & 1.65 & $1.38 ; 1.97$ \\
\hline Four & 248 & 1.8 & 2.04 & $1.52 ; 2.74$ & 2.52 & $1.79 ; 3.57$ \\
\hline Five & 13 & 0.1 & 7.98 & $1.04 ; 61.41$ & 9.83 & $1.12 ; 85.86$ \\
\hline Difficulties in mobility activities & 13,595 & (2.4) & 1.1 & $1.08 ; 1.11$ & 1.09 & $1.06 ; 1.11$ \\
\hline Self-rated Health & 13,569 & (0.9) & 1.11 & $1.07 ; 1.16$ & & \\
\hline \multicolumn{7}{|l|}{ Pain } \\
\hline Yes & 5,838 & 41.3 & 1.05 & $0.98 ; 1.13$ & 0.84 & $0.76 ; 0.93$ \\
\hline \multicolumn{7}{|l|}{ Fall in the last 2 years } \\
\hline Yes & 5,378 & 35.5 & 1.08 & $1.01 ; 1.16$ & & \\
\hline
\end{tabular}


APPENDIX 7 - Model without LCA, including manually SEP-proxies variables

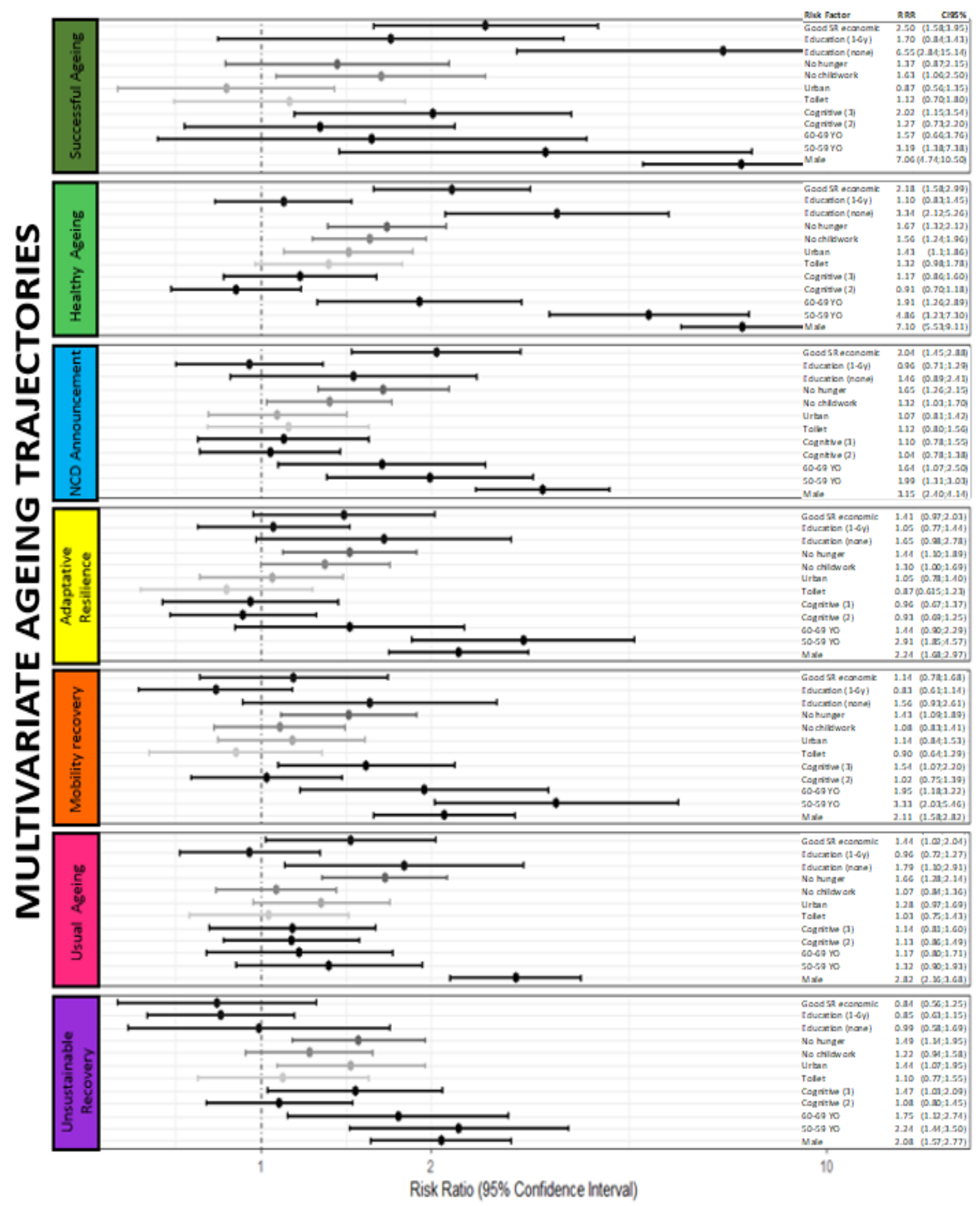




\section{CONCLUSÃO}

A heterogeneidade do envelhecer foi amplamente observada no presente estudo. Independente da população de idosos avaliada, notou-se subgrupos de indivíduos seguindo trajetórias similares em relação a evolução funcional durante a velhice.

Quando comparadas, as coortes de idosos residentes no Brasil (São Paulo) e Chile (Santiago), notamos o impacto da escolaridade na funcionalidade a partir dos 60 anos. Este impacto foi distinto, podendo ser explicado pelo acúmulo de desvantagens ao longo da vida para idosos vivendo no Chile, ao passo que no Brasil a idade (assim como a mortalidade) foram niveladores, absorvendo um pouco o efeito da baixa escolaridade nos piores desfechos funcionais ao longo do tempo.

De uma maneira geral, as trajetórias funcionais estudadas em profundidade na presente tese foram parcialmente guiadas pela idade, mas outros fatores mostraram-se relevante para aumento da chance de fazer parte de determinada trajetória em detrimento de outras.

Tendo como interesse norteador verificar o impacto dos determinantes sociais de saúde nas trajetórias de funcionalidade de idosos, o presente estudo sedimenta a teoria de envelhecimento como um processo ao longo da vida. Sexo (feminino), cor da pele (pretos e pardos), escolaridade (menores níveis educacionais), condições de moradia (piores condições), renda (insuficiência financeira) foram fatores experenciados ao longo da vida que direcionaram os indivíduos para trajetórias menos favorecidas na velhice. Estes fatores vão além da estrutura simplista que os avalia. Por eles inferimos a inserção dos indivíduos na sociedade e o papel que estes acabam por ter ao longo da vida. Vimos que eles permaneceram consistentes, ou poderíamos dizer insistentes, mesmo quando controlados por fatores proximais como condições de saúde no início do estudo, ex.: número de doenças crônicas e condição cognitiva. 


\section{REFERÊNCIAS BIBLIOGRÁFICAS}

1. Nations U, of Economic D, Affairs S, Division P. World Population Prospects: The 2010 Revision, Volume I: Comprehensive Tables [Internet]. New York; 2011. Available from: http://www.un.org/en/development/desa/population/publications/pdf/trends/WPP2010/WP P2010_Volume-I_Comprehensive-Tables.pdf

2. Domingo S, Bárcena A, Prado A, Abramo L, Cecchini S, Espíndola E, et al. The social inequality matrix in Latin America. 2016.

3. ECLAC. Social Panorama of Latin America. Santiago; 2016.

4. Campolina AG, Adami F, Santos JLF, Lebrão ML. A transição de saúde e as mudanças na expectativa de vida saudável da população idosa: possíveis impactos da prevenção de doenças crônicas. Cad Saude Publica. 2013;29(6):1217-29.

5. Verbrugge LM, Latham K, Clarke PJ. Aging With Disability for Midlife and Older Adults. Res Aging. 2017;39(6):741-77.

6. Wolinsky FD, Armbrecht ES, Wyrwich KW. Rethinking functional limitation pathways. Vol. 40, Gerontologist. Gerontological Society of America; 2000. p. 137-46.

7. World Health Organization (WHO). International Classification of Functioning, Disability and Health: ICF. World Health Organization. World Health Organization; 2015. 23 p.

8. Paschoal SMP. Autonomia e Independencia. In: Papaléo Netto M, editor. Gerontologia: a velhice e o envelhecimento em visão globalizada. São Paulo: Atheneu; 2002. p. 313-23.

9. World Health Organization (WHO). World report on aging an health. World Health Organization. Geneva; 2015.

10. Haas S. Trajectories of functional health: The "long arm" of childhood health and socioeconomic factors. Soc Sci Med. 2008;66(4):849-61.

11. Bousquet J, Kuh D, Bewick M, Standberg T, Farrell J, Pengelly R, et al. Operational definition of Active and Healthy Ageing (AHA): A conceptual framework. J Nutr Health Aging. 2015;19(9):955-60.

12. Wloch EG, Kuh D, Cooper R. Is the Hierarchy of Loss in Functional Ability Evident in 
Midlife? Findings from a British Birth Cohort. PLoS One. 2016;11(5):e0155815.

13. Centro Colaborador da Organização Mundial da Saúde para a Família de Classificações Internacionais em Português. Classificação Internacional de Funcionalidade, Incapacidade e Saúde. 1. Ed., 2. Buchalla CM, editor. São Paulo: EDUSP; 2015. 333 p.

14. Ricci NA, Kubota MT, Cordeiro RC. Concordância de observações sobre a capacidade funcional de idosos em assistência domiciliar. Rev Saude Publica. 2005;39(4):655-62.

15. Mutambudzi M, Chen N-W, Howrey B, Garcia MA, Markides KS. Physical Performance Trajectories and Mortality Among Older Mexican Americans. Journals Gerontol Ser A [Internet]. 2019 Jan 16 [cited 2020 Feb 15];74(2):233-9. Available from: https://academic.oup.com/biomedgerontology/article/74/2/233/4846327

16. Ahmed T, French SD, Belanger E, Guerra RO, Zunzunegui MV, Auais M. Gender Differences in Trajectories of Lower Extremity Function in Older Adults: Findings From the International Mobility in Aging Study. J Am Med Dir Assoc. 2019 Oct 1;20(10):11991205.e4.

17. Branch LG, Meng H, Guralnik JM. Disability and Functional Status. In: Prohaska TR, Anderson LA, Binstock RH, editors. Public Health for an Aging Society. Baltimore: The Johns Hopkins University Press; 2012.

18. Katz S, Downs TD, Cash HR, Grotz RC. Progress in Development of the Index of ADL. Gerontologist. 1970;10(1):20-30.

19. Lawton MP, Brody EM. Assessment of older people: self-maintaining and instrumental activities of daily living. Gerontologist. 1969;9(3):179-86.

20. Perracini MR, Fló CM, Guerra RO. Funcionalidade e Envelhecimento. In: Perracini MR, Fló CM, editors. Funcionalidade e Envelhecimento. 1 Ed. Rio de Janeiro: Guanabara Koogan; 2009. p. 3-24.

21. Díaz-Venegas C, Wong R. Trajectories of limitations in activities of daily living among older adults in Mexico, 2001-2012. Disabil Health J [Internet]. 2016;9(3):524-32. Available from: http://www.ncbi.nlm.nih.gov/pubmed/26993585

22. Chen C-M, Su Y-Y, Mullan J, Huang M-S, Chiu H-C. Trajectories of Disability and Their Relationship with Health Status and Social Service Use. Exp Aging Res. 2015;41(3):24058.

23. Yu H-W, Chen D-R, Chiang T-L, Tu Y-K, Chen Y-M. Disability trajectories and associated 
disablement process factors among older adults in Taiwan. Arch Gerontol Geriatr. 2015;60(2):272-80.

24. Martin LG, Zimmer Z, Lee J. Foundations of Activity of Daily Living Trajectories of Older Americans. J Gerontol B Psychol Sci Soc Sci [Internet]. 2017 Sep 2 [cited 2015 Nov 3];72(1):129-39. Available from: http://www.ncbi.nlm.nih.gov/pubmed/26333820

25. Gill TM, Gahbauer EA, Han L, Allore HG. Trajectories of Disability in the Last Year of Life. N Engl J Med. 2010;362(13):1173-80.

26. Williams G. Theorizing Disability. In: Albrecht GL, Seelman K, Bury M, editors. Handbook of Disability Studies. SAGE Publications; 2001. p. 123-42.

27. Jette AM. Toward a common language for function, disability, and health. Phys Ther. 2006;86(5):726-34.

28. Nimrod G, Ben-Shem I. Successful Aging as a Lifelong Process. Educ Gerontol. 2015;41(11):814-24.

29. Nagin D. Group-Based Modeling of Development. Cambridge: Harvard Univ. Press; 2005. $214 \mathrm{p}$.

30. Zimmer Z, Martin LG, Jones BL, Nagin DS. Examining Late-Life Functional Limitation Trajectories and Their Associations With Underlying Onset, Recovery, and Mortality. Journals Gerontol Ser B Psychol Sci Soc Sci [Internet]. 2014 [cited 2018 Sep 13];69(2):275-86. Available from: http://www.ncbi.nlm.nih.gov/pubmed/24531526

31. Daltroy LH, Phillips CB, Eaton HM, Larson MG, Partridge AJ, Logigian M, et al. Objectively measuring physical ability in elderly persons: The physical capacity evaluation. Am J Public Health. 1995;85(4):558-60.

32. Gill TM. Assessment of function and disability in longitudinal studies. J Am Geriatr Soc. 2010 Oct;58(SUPPL. 2).

33. Freiberger E, De Vreede P, Schoene D, Rydwik E, Mueller V, Frändin K, et al. Performance-based physical function in older community-dwelling persons: a systematic review of instruments. 2012 [cited 2020 Mar 4]; Available from: https://academic.oup.com/ageing/article-abstract/41/6/712/13918

34. Stuck AE, Walthert JM, Nikolaus T, Büla CJ, Hohmann C, Beck JC. Risk factors for functional status decline in community-living elderly people: a systematic literature review. Soc Sci Med. 1999;48(4):445-69. 
35. Yu HW, Tu YK, Chen YM. Sociodemographic characteristics, disability trajectory, and health care and long-term care utilization among middle-old and older adults in Taiwan. Arch Gerontol Geriatr. 2019 May 1;82:161-6.

36. Bolano D, Berchtold A, Bürge E. The Heterogeneity of Disability Trajectories in Later Life: Dynamics of Activities of Daily Living Performance Among Nursing Home Residents. J Aging Health [Internet]. 2019 Aug 29 [cited 2020 Feb 15];31(7):1315-36. Available from: http://www.ncbi.nlm.nih.gov/pubmed/29808732

37. Keeney T, Fox AB, Jette DU, Jette A. Functional Trajectories of Persons with Cardiovascular Disease in Late Life. J Am Geriatr Soc [Internet]. 2019 Jan 1 [cited 2020 Feb 15];67(1):37-42. Available from: http://doi.wiley.com/10.1111/jgs.15584

38. Nagin DS, Odgers CL. Group-based trajectory modeling in clinical research. Annu Rev Clin Psychol. 2010;6:109-38.

39. Dannefer D. Systemic and Reflexive: Foundations of Cumulative Dis/Advantage and LifeCourse Processes. Journals Gerontol Ser B. 2018;

40. Ben-Shlomo Y, Cooper R, Kuh D. The last two decades of life course epidemiology, and its relevance for research on ageing. Int J Epidemiol. 2016;45(4):973-88.

41. Wolfson C. A Life Course Approach to Healthy Ageing. Int J Epidemiol. 2016;45(4):dyw139.

42. Marmot M, Wikinson RG. Social determinants of health. 2nd editio. Marmot M, Wilkinson RG, editors. New York: Oxford University Press; 2006. 355 p.

43. Grundy E, van Campen C, Deeg D, Dourgnon P, Huisman M, Ploubidis G. Health inequalities and health divide among older people in the WHO European Region: The European view on the social determinants od health and the health divide. Copenhagen; 2013.

44. McMunn A, Breeze E, Goodman A, Nazroo J, Oldfield Z. Social determinants of health in older age. In: Marmot M, Wilkinson RG, editors. Social determinants of health. New York: Oxford University Press; 2006. p. 267-96.

45. Lynch SM. Race, Socioeconomic Status, and Health in Life-Course Perspective: Introduction to the Special Issue. Res Aging. 2008;30(2):127-36.

46. Heikkinen E. A life course approach: research orientations and future challenges. Eur Rev Aging Phys Act. 2011;8(1):7-12. 
47. Blane D. The life course, the social gradient and health. In: Marmot MG, Wilkinson R, editors. Social determinants of health. 2nd ed. Oxford: Oxford University Press; 2006. p. 54-77.

48. Ben-Shlomo Y, Kuh D. A life course approach to chronic disease epidemiology: conceptual models, empirical challenges and interdisciplinary perspectives. Int J Epidemiol [Internet]. 2002 [cited 2018 Sep 11];31(2):285-93. Available from: https://academic.oup.com/ije/article-lookup/doi/10.1093/ije/31.2.285

49. Ferraro KF, Farmer MM. Double jeopardy, aging as leveler, or persistent health inequality? A longitudinal analysis of white and black Americans. J Gerontol B Psychol Sci Soc Sci [Internet]. 1996 [cited 2019 Jan 7];51(6):S319-28. Available from: http://www.ncbi.nlm.nih.gov/pubmed/8931631

50. WHO. Commission on social determinants of health: note by the Secretariat. Geneva; 2004.

51. Whitehead M, Dahlgren G. Concepts and principles for tackling social inequities in health: Levelling up Part 1 [Internet]. 2006 [cited 2020 Feb 24]. Available from: www.euro.who.int

52. Wilkinson R, Marmot M. Social Determinant os Health: The solid facts. Copenhagen; 2003.

53. Dahlgren G, Whitehead M. Policies and strategies to promote social equity in health. 1991.

54. Geib LTC. Determinantes sociais de saúde do idoso. Cien Saude Colet. 2012;17(1):123-33.

55. Buss PM, Pellegrini Filho A. A saúde e seus determinantes sociais. Physis Rev Saúde Coletiva. 2007;17(1):77-93.

56. Marmot M. The Health Gap - The challenge of an unequal world. London: Bloomsbury; 2015. 387 p.

57. Bernardi L, Huinink J, Settersten RA. The life course cube: A tool for studying lives. Adv Life Course Res. 2018;100258.

58. Vásquez F, Paraje G, Estay M. Income-related inequality in health and health care utilization in Chile, 2000-2009. Rev Panam Salud Publica. 2013;33(2):98-106,.

59. Barbosa AR, Souza JMP, Lebrão ML, Laurenti R, Marucci M de FN. Functional limitations of Brazilian elderly by age and gender differences: data from SABE Survey. Cad Saude Publica [Internet]. 2005;(4):1177-85. Available from: http://www.scielo.br/scielo.php?script=sci_arttext\&pid=S0102$311 X 2005000400020 \& \operatorname{lng}=$ en\&tlng=en

60. Fuentes-García A, Sánchez H, Lera L, Cea X, Albala C. Desigualdades socioeconómicas 
en el proceso de discapacidad en una cohorte de adultos mayores de Santiago de Chile. Gac Sanit. 2013;27(3):226-32.

61. Cat Tuong Nguyen CT, Couture M-C, Alvarado BE, Zunzunegui M-V. Life Course Socioeconomic Disadvantage and Cognitive Function Among the Elderly Population of Seven Capitals in Latin America and the Caribbean. J Aging Health [Internet]. 2008 [cited 2018 Sep 7];20(3):347-62. Available from: http://www.ncbi.nlm.nih.gov/pubmed/18332188

62. Torres JM, Rizzo S, Wong R. Lifetime Socioeconomic Status and Late-life Health Trajectories: Longitudinal Results From the Mexican Health and Aging Study. Journals Gerontol Ser B Psychol Sci Soc Sci. 2016;73(2):349-60.

63. Hosseinpoor AR, Williams JS, Jann B, Kowal P, Officer A, Posarac A, et al. Social determinants of sex differences in disability among older adults: a multi-country decomposition analysis using the World Health Survey. Int J Equity Health. 2012;11(52).

64. Hambleton IR, Howitt C, Jeyaseelan S, Murphy MM, Hennis AJ, Wilks R, et al. Trends in Longevity in the Americas: Disparities in Life Expectancy in Women and Men, 1965-2010. PLoS One. 2015;10(6):e0129778.

65. Alexandre T da S, Corona LP, Nunes DP, Santos JLF, Duarte YA de O, Lebrão ML. Gender differences in incidence and determinants of disability in activities of daily living among elderly individuals: SABE study. Arch Gerontol Geriatr. 2012;55(2):431-7.

66. Rosa TEDC, Benício MHD, Latorre MRD de O, Ramos LR. Fatores determinantes da capacidade funcional entre idosos . Rev Saúde Pública. 2003;37(1):40-8.

67. Zimmer Z, Martin LG, Nagin DS, Jones BL. Modeling Disability Trajectories and Mortality of the Oldest-Old in China. Demography. 2012;49(1):291-314.

68. Pakpahan E, Hoffmann R, Kröger H. The long arm of childhood circumstances on health in old age: Evidence from SHARELIFE. Adv Life Course Res [Internet]. 2017 [cited 2019 Feb 4];31:1-10. Available from: https://www.sciencedirect.com/science/article/pii/S1040260816300569

69. Brown TH, O'Rand AM, Adkins DE. Race-Ethnicity and Health Trajectories. J Health Soc Behav. 2012;53(3):359-77.

70. Warner DF, Brown TH. Understanding how race/ethnicity and gender define agetrajectories of disability: An intersectionality approach. Soc Sci Med [Internet]. 
2011;72(8):1236-48.

Available

from:

https://www.sciencedirect.com/science/article/pii/S0277953611001353

71. Heckhausen J, Buchmann M. A multi-disciplinary model of life-course canalization and agency. Adv Life Course Res. 2018;

72. Marmot M. Just societies, health equity, and dignified lives: the PAHO Equity Commission. Lancet [Internet]. 2018;0(0). Available from: http://www.ncbi.nlm.nih.gov/pubmed/30262335

73. Likas A, Vlassis N, J. Verbeek J. The global k-means clustering algorithm. Pattern Recognit. 2003;36(2):451-61.

74. Nagin DS. Group-based modeling of development. Cambridge, MA: Harvard University Press; 2005.

75. Brown TH, O'Rand AM, Adkins DE. Race-Ethnicity and Health Trajectories. J Health Soc Behav. 2012;53(3):359-77.

76. Xu X, Liang J, Bennett JM, Botoseneanu A, Allore HG. Socioeconomic Stratification and Multidimensional Health Trajectories: Evidence of Convergence in Later Old Age. Journals Gerontol Ser B Psychol Sci Soc Sci. 2015;70(4):661-71.

77. Lebrão ML, Duarte YA de O. O projeto SABE no município de São Paulo: uma abordagem inicial. Organização Pan-Americana de Saúde - OPAS/OMS. 2003. p. 255.

78. Katz S, Ford AB, Moskowitz RW, Jackson BA, Jaffe MW. Studies of Illness in the Aged. The Index of ADL: a standardized meadure of biological and psychosocial function. J Am Med Assoc. 1963;185(12):914-9.

79. Yesavage JA, Sheikh JI. Geriatric Depression Scale (GDS): Recent evidence and development of a shorter version. Clin Gerontol [Internet]. 1986;5(1-2):165-73. Available from: https://www.tandfonline.com/doi/full/10.1300/J018v05n01_09

80. Barbosa BR, Almeida JM de, Barbosa MR, Rossi-Barbosa LAR, Barbosa BR, Almeida JM de, et al. Avaliação da capacidade funcional dos idosos e fatores associados à incapacidade. Cien Saude Colet [Internet]. 2014 Aug;19(8):3317-25. Available from: http://www.scielo.br/scielo.php?script=sci_arttext\&pid=S1413$81232014000803317 \& \operatorname{lng}=$ pt\&nrm=iso\&tlng=en

81. Casey R. Disability and unmet health care needs in Canada: A longitudinal analysis. Disabil Health J [Internet]. 2015;8(2):173-81. Available from: 
https://www.sciencedirect.com/science/article/pii/S1936657414001538

82. Fuentes-García A, Sánchez H, Lera L, Cea X, Albala C. Desigualdades socioeconómicas en el proceso de discapacidad en una cohorte de adultos mayores de Santiago de Chile. Gac Sanit [Internet]. 2013;27(3):226-32. Available from: https://www.sciencedirect.com/science/article/pii/S0213911112003263

83. Melnykov V, Maitra R. Finite mixture models and model-based clustering. Stat Surv. 2010;4:80-116. 


\section{ANEXO I - APROVAÇÃO COMITÊ DE ÉTICA EM PESQUISA}

MINISTERIO DA SAULDE

Conselho Nacional de Saude

Comrasắ Nacinnal de Etica em Pesquisa - CONEP

\section{PARECER N N $^{\circ} 315 / 99$}

Processo $\pi^{\circ} 25000.024350 / 99.80$

Registro CONEP $=675$ (Protocolo CEP :198) Projeto de Pesquisa: "As condiçoes de saudo dos idosos na América do Sul .
Canibe.

Pesquieador Responsável: Dr. Ruy Laurenti Institulçăo: F æaculdade de Saúde Pübica / USP

Área Temática Especial Pesquisa com cooperaçăo estrangaira

Ao se proceder à análise do protocolo em questăo. cabem as saguintes consideraçōes:

a) es informaçöes enviadas atendem aos aspectos fundamentais das Res CNS 196/96 e 251/87. sobre Diretrizes e Normas Regulamentadoras de Pesquisas Envolvendo Seres Humanos:

b) o projeto foi aprovado pelo Comitê de Ética em Pesquisa - CEP da instituiç्⿹ีం

Diante do exposto, a Comissào Naoional de Ética em Pesquisa CONEP, de a cordo com as atribuiçóes da Res. CNS 196/96, manifesta - se pela aprovaç̆o do projeto de pesquisa proposto, com a oeguinto recomendaçlo a ser acompanhada peio CEP.

1) Crçamento financero detathado especificando a remuneraçăo do pesquisador ( Res CNS 195/96. VI:"J").

Situação: Projeto aprovado com recomendação.

Brasilia, 17 de junho de 1999.

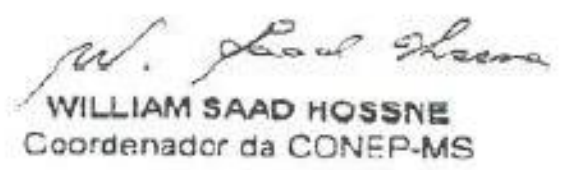


Universidade de São Paulo

Faculdade de Saúde Pública

COMITÊ DE ÉTICA - COEP

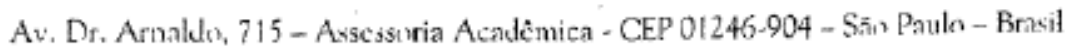

Telcfones: (55-11) 3066-7779- s-mail: cocporefsp.usp.hr

\section{Of.COEP $/ 83 / 06$}

14 de máç̧o de 2006

Pelo presente, informo que o Comitê de Ética em Pesquisa da Faculdade de Saúde Pública da Universidade de São Paulo-COEP, aprovou o Protocolo de Pesquisa n. ${ }^{\circ}$ 1345, intitulado: "PROJETO SABE-2005 - SAÚDE, BEM-ESTAR E ENVELHECIMENTO. AS CONDIÇÓES DE SAÚDE E DE VIDA DOS IDOSOS NO MUNICÍPIO DE SÄO PAULO", apresentado pela pesquisadora Maria Lúcia Lebrăo.

Atenciosamente,

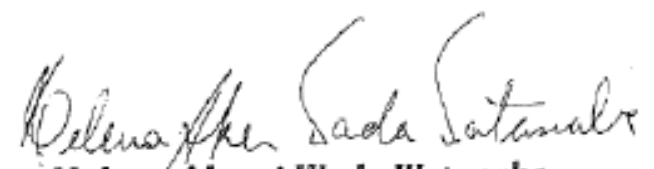

Helend Akeml Wada Watanabe Professora Doutora

Vice-Coordenadora do Comitê de F́tica em Pesquisa da FSP-COEP 


\section{COMITEE DE ÉTICA EM PESQUISA - COEP/FSP}

Universidade de São Paulo

Faculdade de Saúde Pública

OF,COEP/23/10

5 de março de 2010.

Prezado(a) Pesquisador(a) e Orientador(a),

o Comité de Ética em Pesquisa da Faculdade de Saúde Pública da Unjversidade de SJo Paujo - COEP/FSP, analisou, de acordo cam a Resciuçäo N.O 196/96 do Conselho Nacional de Saúde - CNS e suas complementares, o protocolo de pesquisa n.0 2044, intitulado "ESTUDO SABE 2010: SAÚDE, BEM-ESTAR E ENVELHECTMENTO - ESTUDO LONGITUDINAL SOBRE AS CONDIÇÕES DE VIDA E SAÚDE DOS IDOSOS NO MUNTCf́PIO DE SĂO PAULO", área temática GRUPO III, sob responsabilidade do(a) pesquisador(a) Maria Lucia Lebrao, e considerou que a pendência anteriommente apresentada por este COEP fol atendida. Protocolo de pesquisa APROVADO "ADREFERENDUM".

Cabe lembrar que conforme Resolugăo CN /196/96, săo deveres do (a) pesquisador (a): 1. Comunicar, de imediato, qualquer alteraçăo no projeto e aguardar manifestaçăo deste CEP (Comité de Ética em Pesquisa), para dar continuidade à pesquisa; 2. Manter sob sua quarda e em iocal sequro, pelo prazo de 5 (cinco) anos, os dados da pesquisa, contendo fichas individuais e todos os demals documentos recomendados pelo CEP, no caso evertual auditoria; 3. Comunicar formalmente a este Comitê, quando do encerramento deste projeto; 4. Elaborar e apresentar relatónios parcials e final; 5. Justificar, perante o CEP, interrupç̃o do projeto ou a nåo publicaçăo dos resultados.

Atenciosamente,

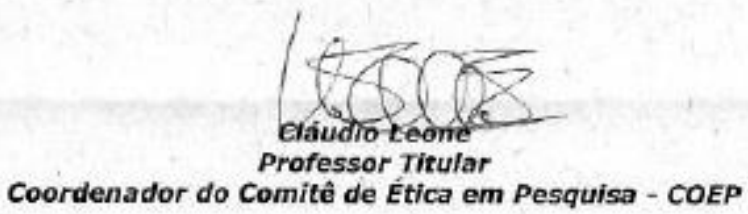

I/m. a Sr.a

Prof. * Tit. Maria Lucia Lebrăo

Departamento de Epidemiologia da FSP/USP

Av. Dr. Arnaldo, 715 - Assessoria Acadêmica - CEP: 01246-904 - Säo Paulo - SP Telefones: (55-11) 3061-7779/7742 e-mail: coep@fsp.usp.br site www.fsp.usp.br 


\section{USP - FACULDADE DE SAÚDE PÚBLICA DA UNIVERSIDADE DE SÃO PAULO - FSP/USP}

\section{PARECER CONSUBSTANCIADO DO CEP}

\section{DADOS DO PROJETO DE PESQUISA}

Título da Pesquisa: ESTUdO SABE - SAÚDE, BEM-ESTAR E ENVELHECIMENTO - Coorte 2015

Estudo longitudinal de múltiplas coortes sobre as condições de vida e saúde dos idosos no Município de Säo Paulo.

Pesquisador: YEDA APARECIDA DE OLIVEIRA DUARTE

Área Temática:

Versäo: 2

CAAE: 47683115.4 .0000 .5421

Instituiçäo Proponente: Faculdade de Saúde Pública da Universidade de Säo Paulo - FSP/USP

Patrocinador Principal: FUNDACAO DE AMPARO A PESQUISA DO ESTADO DE SAO PAULO

DADOS DO PARECER

Número do Parecer: 3.600 .782

Apresentaçäo do Projeto:

Trata-se de projeto temático sobre saúde do idoso, com base em amostra representativa e seguimento longitudinal ( $4 \mathrm{a}$ onda) de residentes na cidade de Säo Paulo.

Objetivo da Pesquisa:

Descrever e analisar padröes de vida e de saúde de idosos na cidade de São Paulo, bem como de seus determinantes e fatores associados.

Avaliação dos Riscos e Benefícios:

O projeto equacionou adequadamente a avaliação de riscos e benefícios. Já foi aprovado para as ondas anteriores e já havia sido aprovado quanto a esse quesito para a corrente avaliação da $4 a$ onda do seguimento longitudinal.

Comentários e Consideraçöes sobre a Pesquisa:

A única pendência levantada dizia respeito à solicitação de informações adicionais quanto ao envio ao exterior de amostras de sangue para a realização de exames genéticos de interesse para o estudo.

Considerações sobre os Termos de apresentação obrigatória:

Foram apresentados os termos obrigatórios. O TCLE informa adequadamente aos participantes do

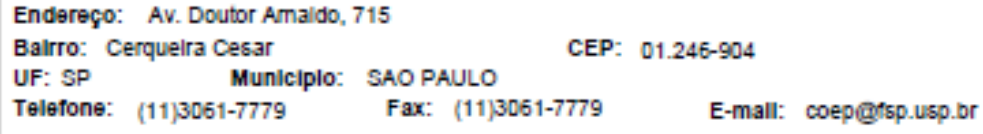




\section{USP - FACULDADE DE SAÚDE \\ PÚBLICA DA UNIVERSIDADE DE SÃO PAULO - FSP/USP

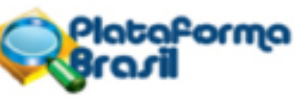

Conthusço do Parecer. 3.600 .792

estudo de que sua amostra de sangue poderá ser levada ao exterior para a realização de exames genéticos de interesse para o estudo.

Conclusões ou Pendências e Lista de Inadequações:

Considero que os esclarecimentos adicionais prestados pela proponente são suficientes e recomendo aprovação do presente projeto.

Considerações Finais a critério do CEP:

Este parecer foi elaborado baseado nos documentos abaixo relacionados:

\begin{tabular}{|c|c|c|c|c|}
\hline Tipo Documento & Arquivo & Postagem & Autor & Situação \\
\hline $\begin{array}{l}\text { Informaçōes Básicas } \\
\text { do Projeto }\end{array}$ & $\begin{array}{l}\text { PB_INFORMAÇÖES_BÁSICAS_DO_P } \\
\text { ROJETO_518377.pdf }\end{array}$ & $\begin{array}{c}24 / 07 / 2019 \\
16: 52: 18 \\
\end{array}$ & & Aceito \\
\hline Outros & Resposta_pendencia_Yeda.docx & $\begin{array}{c}24 / 07 / 2019 \\
16: 51: 38\end{array}$ & $\begin{array}{l}\text { YEDA APARECIDA } \\
\text { DE OLIVEIRA } \\
\text { DUARTE }\end{array}$ & Aceito \\
\hline $\begin{array}{l}\text { Declaração de } \\
\text { concordấncia }\end{array}$ & Justificativasabe.pdf & $\begin{array}{c}14 / 02 / 2017 \\
17: 23: 46\end{array}$ & $\begin{array}{l}\text { Márcia Ferreira dos } \\
\text { Santos }\end{array}$ & Aceito \\
\hline \begin{tabular}{|l|} 
Solicitação \\
registrada pelo CEP
\end{tabular} & Deacordosabe.pdf & $\begin{array}{c}14 / 02 / 2017 \\
17: 23: 46 \\
\end{array}$ & \begin{tabular}{|l|} 
Márcia Ferreira dos \\
Santos
\end{tabular} & Aceito \\
\hline $\begin{array}{l}\text { TCLE / Termos de } \\
\text { Assentimento / } \\
\text { Justificativa de } \\
\text { Ausència } \\
\end{array}$ & TCLE03092015.pdf & $\begin{array}{c}03 / 09 / 2015 \\
12: 27: 45\end{array}$ & $\begin{array}{l}\text { MARIA LUCIA } \\
\text { LEBRÃOO }\end{array}$ & Aceito \\
\hline Folha de Rosto & pagina rosto Coep SABE 15.pdf & $\begin{array}{c}15 / 06 / 2015 \\
13: 09: 04\end{array}$ & & Aceito \\
\hline $\begin{array}{l}\text { Projeto Detalhado / } \\
\text { Brochura } \\
\text { Investigador }\end{array}$ & Projeto SABE 2015.pdf & $\begin{array}{c}08 / 06 / 2015 \\
21: 09: 45\end{array}$ & & Aceito \\
\hline
\end{tabular}

Situação do Parecer:

Aprovado

Necessita Apreciação da CONEP:

Näo

Endereço: Av. Doutor Amaldo, 71

Bailro: Cerquelra Cesar

UF: SP

Municiplo: SAO PAULO

CEP: $01.246-904$

Telefone: (11)3061-7779

Fax: (11)3061-7779

E-mall: coepotsp.usp.br 


\section{USP - FACULDADE DE SAÚDE PÚBLICA DA UNIVERSIDADE Plotoforma DE SÃO PAULO - FSP/USP}

SAO PAULO, 26 de Setembro de 2019

Assinado por:

José Leopoldo Ferreira Antunes

(Coordenador(a))

Endereço: Av. Doutor Amaldo, 715 


\title{
APÊNDICE 1 - COMPROVANTE DE SUBMISSÃO DO ARTIGO 1
}

\author{
European Journal of Ageing \\ Cumulative Inequalities: is age a leveler? The case of functional trajectories of older \\ adults in two middle-income countries \\ --Manuscript Draft--
}

\begin{tabular}{|c|c|c|}
\hline Manuscript Number: & \multicolumn{2}{|l|}{ EJOA-D-19-00254 } \\
\hline Full Title: & \multicolumn{2}{|c|}{$\begin{array}{l}\text { Cumulative Inequalities: is age a leveler? The case of functional trajectories of older } \\
\text { adults in two middle-income countries }\end{array}$} \\
\hline Article Type: & \multicolumn{2}{|l|}{ Original Investigation } \\
\hline Corresponding Author. & \multicolumn{2}{|c|}{$\begin{array}{l}\text { Alejandra Fuentes-García, PhD } \\
\text { Universidad de Chile Escuela de Salud Publica } \\
\text { Santiago, CHILE }\end{array}$} \\
\hline \multicolumn{3}{|l|}{$\begin{array}{l}\text { Corresponding Author Secondary } \\
\text { Information: }\end{array}$} \\
\hline Corresponding Author's Institution: & \multicolumn{2}{|c|}{ Universidad de Chile Escuela de Salud Publica } \\
\hline $\begin{array}{l}\text { Corresponding Author's Secondary } \\
\text { Institution: }\end{array}$ & \multicolumn{2}{|c|}{ Universidad de Chile Escuela de Salud Publica } \\
\hline First Author: & \multicolumn{2}{|l|}{ Etienne Duim, M.D. } \\
\hline \multicolumn{3}{|l|}{ First Author Secondary Information: } \\
\hline \multirow[t]{5}{*}{ Order of Authors: } & \multicolumn{2}{|l|}{ Etienne Duim, M.D. } \\
\hline & \multicolumn{2}{|l|}{ Alejandra Fuentes-García, PhD } \\
\hline & \multicolumn{2}{|l|}{ Cecilia Albala } \\
\hline & \multicolumn{2}{|l|}{ Yeda Aparecida de Oliveira Duarte } \\
\hline & \multicolumn{2}{|l|}{ José Leopoldo Ferreira Antunes } \\
\hline \multicolumn{3}{|c|}{ Order of Authors Secondary Information: } \\
\hline \multirow[t]{4}{*}{ Funding Information: } & $\begin{array}{l}\text { Fondecyt } \\
\text { (10 80 589) }\end{array}$ & Not applicable \\
\hline & $\begin{array}{l}\text { Fondecyt } \\
\text { (1130947) }\end{array}$ & Not applicable \\
\hline & $\begin{array}{l}\text { Fundação de Amparo à Pesquisa do } \\
\text { Estado de São Paulo } \\
\text { (2016/19696-3) }\end{array}$ & MSc Etienne Duim \\
\hline & $\begin{array}{l}\text { Proyecto Internacionalización UChile } \\
(1566)\end{array}$ & Not applicable \\
\hline Abstract: & \multicolumn{2}{|c|}{$\begin{array}{l}\text { Background: Functional trajectories offer a broad view of the older individual's health } \\
\text { condition and involve social inequalities as a predictor. Objective: To compare the } \\
\text { impact of educational level on later life disadvantaged functional trajectories of older } \\
\text { adults in Brazil and Chile. Method: A cross-country study using data from the } 2000 \text {, } \\
2005 \text { and } 2010 \text { Health, Aging and Well Being Surveys (SABE Study) in Brazil ( } \mathrm{n}=685 \text { ) } \\
\text { and Chile (n=285). Individuals aged } 260 \text { years were clustered using a deterministic } \\
\text { approach based on their functioning during the study period. Logistic regression } \\
\text { models were fitted for trajectory groups with additional marginal probability analysis. } \\
\text { Results: The Chilean group had a lower prevalence of functional limitation at baseline } \\
\text { ( } 32.6 \% \text { versus } 41.7 \% \text { ) and higher level of education ( } 28 \text { years: } 33.7 \% \text { versus } 17.1 \% \text { ) } \\
\text { compared with the Brazilian sample. Chilean older adults with } \leq 3 \text { years of education } \\
\text { were more likely to have a vulnerable trajectory than those with higher educational } \\
\text { level (Odds Ratio } 2.9 \text {. } 95 \% \text { Confidence Interval (CI) } 1.45 ; 10.59 \text { ). while Brazilians who } \\
\text { never attended school had } 95 \% \text { higher odds ( } 95 \% \text { Cl } 1.04 ; 3.63 \text { ) of belonging to the } \\
\text { worst trajectory than those who attended school. In Brazil, the older an individual, the } \\
\text { higher the probability of belonging to the advantageous trajectory and the lower the } \\
\text { influence of education. For older adults in Chile, educational level continued to } \\
\text { influence the probability of a disadvantaged trajectory. with additional influence of age. } \\
\text { Conclusion: Inequality of access to education proved a predictor of disadvantaged }\end{array}$} \\
\hline
\end{tabular}

Powered by Editorial Manager(a) and ProduXion Manager(1) from Aries Systems Corporation 
trajectory, with a substantial difference between these populations.

Powered by Editorial Manager(10) and ProduXion Manager(19) from Aries Systems Corporation 


\title{
APÊNDICE 2 - COMPROVANTE DE SUBMISSÃO E ACEITE DO ARTIGO 3
}

\author{
Elsevier Editorial System(tm) for Archives \\ of Gerontology and Geriatrics \\ Manuscript Draft
}

Manuscript Number:

Title: Highways to Ageing - Linking life course SEP to multivariate

trajectories of health outcomes in older adults

Article Type: Full Length Article

Keywords: Trajectories; Functioning; Chronic diseases; Life course epidemiology

Corresponding Author: Ms. Etienne Duim,

Corresponding Author's Institution: University of Sao Paulo - School of Public Health

First Author: Etienne Duim

Order of Authors: Etienne Duim; Valéria Lima Passos

Abstract: Objectives: Ageing is a temporal, multi-faceted process, whose unfolding is subject to a several interacting factors: e.g. genetic, environmental/contextual, behavioral and socio-economic. In this study, we used life course and multidimensional approaches to elucidate the association between socioeconomic forces across a lifetime and the developmental origins in health and disease of the Mexican elderly. Methods: Data stemmed from the Mexican Health and Ageing Study, constituting a sample of older adults ( $N=5169,>50$ years). With retrospective information on early, intermediary and current socioeconomic indicators, life course typologies of socioeconomic position were identified using Latent Class Analysis. Based on prospective data of functional mobility, number of chronic conditions and self-rated health, multivariate trajectories of health outcomes were uncovered with Group Based Trajectory Model. Links between the extracted SEP and multivariate health latent constructs were explored with multinomial logistic regression.

Results: Life course SEP classes were heterogeneous, yet a large proportion of subjects was characterized by persistent socioeconomic adversity throughout life. The outcomes' patterns of co-evolution were diverse too, shedding light on the strength of their temporal links, while revealing variable synchronicity in their temporal decline. Lastly, a conspicuous graded association was observed between the SEP classes and ageing trajectories, with subjects of less advantageous SEP classes being more likely to age vulnerably.

Conclusion: Ageing is not one-model fits all process of deterioration but, rather, naturally variable. The findings provide life course evidence for the distinct ways socio-economic forces can shape ageing developmental courses. 
Ms. Ref. No.: AGG-D-19-01066R2

Title: Highways to Ageing - Linking life course SEP to multivariate trajectories of health outcomes in older adults Archives of Gerontology and Geriatrics

Dear Ms. Etienne Duim,

I am pleased to inform you that your paper "Highways to Ageing - Linking life course SEP to multivariate trajectories of health outcomes in older adults" has been accepted for publication in Archives of Gerontology and Geriatrics.

Below are comments from the editor and reviewers. Your accepted manuscript will now be transferred to our production department and work will begin on creation of the proof. If we need any additional information to create the proof, we will let you know. If not, you will be contacted again in the next few days with a request to approve the proof and to complete a number of online forms that are required for publication.

Thank you for submitting your work to Archives of Gerontology and Geriatrics.

Yours sincerely,

Liang-Kung Chen, M.D. PhD

Editor

Archives of Gerontology and Geriatrics

Comments from the editors and reviewers:

For further assistance, please visit our customer support site at http://help.elsevier.com/app/answers/list/p/7923. Here you can search for solutions on a range of topics, find answers to frequently asked questions and learn more about EM via interactive tutorials. You will also find our 24/7 support contact details should you need any further assistance from one of our customer support representatives.

In compliance with data protection regulations, you may request that we remove your personal registration details at any time. (Use the following URL:

https://www.editorialmanager.com/agg/login.asp?a=r). Please contact the publication office if you have any questions. 


\section{APÊNDICE 3 - CURRÍCULO LATTES - ETIENNE DUIM}

$27 / 04 / 2020$

Curriculo Lattes

9 Cumiouio Lattes

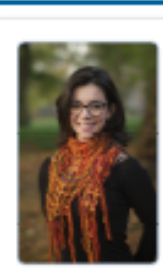

Etienne Duim

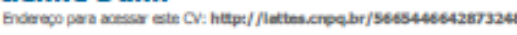

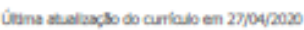

Resumo informado pelo autor

Fisicterapeuta, Espedaista em Saúde Coletiva e Saúde da Familia, ambos pelo Centro Universitário Filadéfla. Mestre em Cänclas pela Escola de Enfermagem da USP, enquarto discente no Programa de Pós-Graduaço em Enfermagem na Saúde do Adulo (PROESA). Candidata a thulo de Doutora em Epidemicicgla pela Faculdade de Saúde Pública da Universidade de Säo Paula. Integra o grupo de pesquisa sobre Saúde Pública e Ervelhecimento da USP. Atua camo Epidemiologista no Hospital Israsterse Albert Enstein no setor de Inteligetncia en Saúde Populacional.

(Terto Informado pelo autor)

Nome social

Nomo Elienne Duim

Dados pessoais

Fillogsto Edy Cratna Dum Negin

Nacolmento 1901/1988-Camberp-Bras

Carteira de 87729834 88P-PR-25/07/2006

Identidade

CPF 058.78242962

Formação acadêmica/titulação

2018 Doutorado em Doutorado em Epideniolog

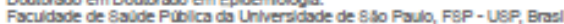

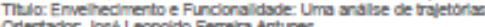

Orlertador. Jost Leopoido Ferrera Avturea

2014 - 2018 Mestado em PRoEsA

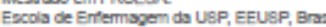

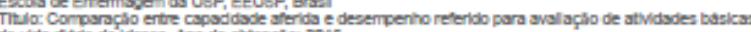

de vida diara de idosos, Ano de obbenglato: 2016

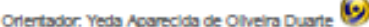

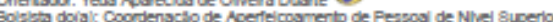

2012 - 2013 Espectalzaplo em 8sude Coietva e 8aude do Familla

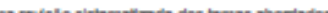

Orertador. Damses Tomialn Bayin

2007 - 2010 Gradiacilo em Faicterapla.

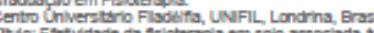

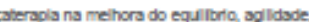

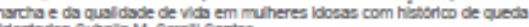

Oreetador. Sunala M. 8mall santaa

Formação complementar

\footnotetext{
2008 Dençaterapla.

Egculats de Dormaterapla Maria Fux, EDMF, Aventina

2017 - 2017 Curso de arta diroçlo em Curso de Ahulzapho Mutprotzzional de Culdados Palstuos. (Carga hordra:

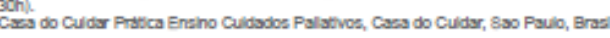

1996 - 2004 Balet Cisgelco. . (Carpa hordirs 6240h).

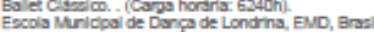

Atuação profissional 
Artigos completos publicados em periódicos

1. doi> YAZBEK, BEATRIZ; RAHAL, MARIANA; MELLO, JÚLIA; MAGALHAES, LUIZA; FALLEIROS, FERNANDA; SILVA, JULIANA; DUIM, ETIENNE; SOUSA, FRANCISCO; CIACCIA, MARIA CELIA; RULLO, VERA Hypertensive Disorders of Pregnancy and Recurrent Wheezing: 18 Month Follow-up Of A Birth Cohort Study. JOURNAL OF ALLERGY AND CLINICAL IMMUNOLOGY JCR, v.145, p.AB207 - 2020

2. doi> DE SOUZA, SUZANA; DUIM, ETIENNE; NAMPO, FERNANDO KENJI

Determinants of neonatal mortality in the largest international border of Brazil: a case-control study. BMC PUBLIC HEALTH. JCR, v.19, p.1 - 9, 2019

3. doj》 FAJERSZTAJN, LAíS; GUIMARÃES, MARIANA TAVARES; DUIM, ETIENNE; SILVA, TARSILA GUIMARÃES VIEIRA DA; OKAMURA, MIRNA NAMIE; BRANDÃO, SUZAN LÚCIA BRANCHER; RIBEIRO, ANA ELISA; NAUD, LUDMILA MACÉDO; O'SULLIVAN, SHANE; SALDIVA, PAULO HILÁRIO NASCIMENTO; CARDOSO, MARIA REGINAALVES

Health effects of pollution on the residential population near a Brazilian airport. A perspective based on literature review. Journal of Transport \& Health. JCR , v.14, p.100565 $-, 2019$.

4. dOI> RAHAL, MARIANA ABDUCH; MAGALHÃES, LUIZA RIBEIRO; SILVA, JULIANA RINALDIS; FALLEIROS, FERNANDA TANIGUCHI; DUIM, ETIENNE LARISSA PEREIRA SOUSA, FRANCISCO LAZARO; CUNHA CIACCIA, MARIA CELIA; RULLO, VERAE. Hypertensive Disorders of Pregnancy and Recurrent Wheezing: 12 Month Follow-up of a Birth Cohort Study. JOURNAL OF ALLERGY AND CLINICAL IMMUNOLOGY JCR, v.143, p.AB76 - , 2019

5. doi> DE ALMEIDA ROEDIGER, MANUELA; DE FÁTIMA NUNES MARUCCI, MARIA; DUIM, ETIENNE LARISSA; SANTOS, JAIR LíCIO FERREIRA; DE OLIVEIRA DUARTE, YEDA APARECIDA; DE OLIVEIRA, CESAR

Inflammation and quality of life in later life: findings from the health, well-being and aging study (SABE). Health and Quality of Life Outcomes. JCR , v.17, p.1 - , 2019.

6. doi> DE SIQUEIRA CORRADI, MATHEUS BARTOLOMEI; D'ÁVILA, RONALDO; DUIM, ETIENNE; RODRIGUES, CIBELE ISAAC SAAD

Risk stratification for complications of laparoscopic cholecystectomy based on associations with sociodemographic and clinical variables in a public hospital. AMERICAN JOURNAL OF SURGERY. JCR, v.219, p.645 - 650,2019

7. doi> NEGRINI, ETIENNE LARISSA DUIM; NASCIMENTO, CARLA FERREIRA DO; SILVA, ALEXANDRE DA; ANTUNES, JOSÉ LEOPOLDO FERREIRA

Elderly persons who live alone in Brazil and their lifestyle. REVISTA BRASILEIRA DE GERIATRIA E GERONTOLOGIA. , v.21, p.523 - 531, 2018.

8. doi> OLAVE-MŪLLER, PAOLA; LÓPEZ-CONTRERAS, NATALIA; CIRANO-MÉNDEZ, GABRIEL; DUIM, ETIENNE; MUÑOZ-MARDONES, JAVIERA Enabling Elements for the Implementation of Community Health Promoter Led Interventions: A Literature Review. INTERNATIONAL JOURNAL OF ODONTOSTOMATOLOGY, v.12, p.437 - 444, 2018

9. doi> BURALLI, RAFAEL JUNQUEIRA; CANELAS, TIAGO; CARVALHO, LAURA MARTINS DE; DUIM, ETIENNE; ITAGYBA, RENATA FORTES; FONSECA, MARILIA;

OLIVER, SOFIA LIZARRALDE; CLEMENTE, NÚRIA SANCHEZ , 2018 .

10. doi> LAMBERT, LETICIA; SAVASTANO, LUISA B.; VARGAS, SEPHANIE L.; DUIM, ETIENNE L.; CIACCIA, MARIA CELIA C.; RULLO, VERA E Overweight/Obesity as a risk factor for Severe Wheezing up to 5 years old. JOURNAL OF ALLERGY AND CLINICAL IMMUNOLOGY. JCR, v.141, p.AB4 - , 2018.

11. FILIZZOLA, F. C.; SECOMANDI, P. T. G.; ROSA, N. F.; MASSARO, N.; BRITO, L. M.; DUIM, E. L.; CIACCIA, M. C. C.; RULLO, V. E. V. Desenvolvimento Motor Grosso em Crianças frequentadoras e não frequentadoras de creches e fatores associados. REVISTA UNILUS ENSINO E PESQUISA (ONLINE). v. 14, p. $100-111,2017$

12. Uి doì DUIM, ETIENNE; LEBRÃO, MARIA LUCIA; ANTUNES, JOSÉ LEOPOLDO FERREIRA Walking speed of folder people and pedestrian crossing time. Journal of Transport \& Health. JCR. v.SI, p.1 - 7, 2017

13. đoỉ DUIM, ETIENNE; SÁ, FELIPE HENRIQUE CARDOSO DE; DUARTE, YEDA APARECIDA DE OLIVEIRA; OLIVEIRA, RITA DE CASSIA BURGOS DE; LEBRÃO, MARIA LUCIA

Prevalência e características das feridas em pessoas idosas residentes na comunidade. Revista da Escola de Enfermagem da USP (Online). JCR v.49, p.51 - 57, 2015.

14. TONON, P.P.; DUIM, E. L.

Efetividade da fisioterapia associada à dançaterapia na melhora da capacidade aeróbica e flexibilidade de mulheres idosas com histórico de queda. Saúde e Pesquisa. v.5. p. $517-524,2012$.

Artigos aceitos para publicação

1. CORRADI, M. L. G.; DUIM, ETIENNE L.; RODRIGUES, CIBELE ISAAC SAAD

Death, palliative care, and the end of life: physicians' perceptions throughout the career and educational process. JOURNAL OF PALLIATIVE CARE. JCR 2020.

Capitulos de livros publicados

1. BURALLI, RAFAEL JUNQUEIRA; OLIVEIRA, N. T. B.; DUIM, ETIENNE O MÉTODO PILATES NA PREVENÇÃOO DE DOENÇAS E PROMOÇÄO DA SAÚDE EM IDOSOS: UMA REVISÃ̃ SISTEMÁTICA In: Atualizações em pilates clínico... ed.São Paulo: Opção Livros, 2018, v.1, p. 59-78. 


\title{
APÊNDICE 4 - CURRÍCULO LATTES PROFESSOR JOSÉ LEOPOLDO FERREIRA ANTUNES
}

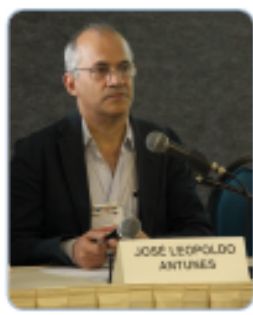

\author{
José Leopoldo Ferreira Antunes \\ Bolsista de Produtividade em Pesquisa do CNPq - Nível 1A \\ Endereco para acessar este CV: http://lattes.cnpq.br/4938720890035457 \\ ID Lattes: 4938720890035457 \\ Última atualizaço do curriculo em 26/04/2020
}

José Leopoldo Ferreira Antunes é professor titular da Faculdade de Saúde Pública da Universidade de São Paulo, Editor Científico da Revista de Saúde Pública e Editor Associado de Oral Diseases. É pesquisador do CNPq desde 03/2001. Sua área de interesse em pesquisa é a vigilância das desigualdades em saúde, com foco em suas formas de medida, na avaliação de sua magnitude e fatores associados. Em especial, tem se aplicado ao estudo do impacto de programas e intervencoões sobre as desigualdades socioeconômicas em saúde. (Texto informado pelo autor)

Identificação

\begin{tabular}{|c|c|}
\hline Nome & José Leopoldo Ferreira Antunes \\
\hline Nome em citagões bibliográficas & $\begin{array}{l}\text { ANTUNES, J. L. F.;ANTUNES JLF;ANTUNES, J. L;ANTUNES JL;Antunes, José L.F.;Antunes, } \\
\text { José Leopoldo Ferreira;Ferreira Antunes, José Leopoldo;Antunes, Jose Leopoldo } \\
\text { Ferreira;Antunes, JosÄ@e Leopoldo Ferreira;Antunes LF;Antunes, José Leopoldo;ANTUNES, } \\
\text { JOSÉ LEOPOLDO F.;ANTUNES, JOSE L;;ANTUNES, JOSÉ LFOPOLDO F;ANTUNES, } \\
\text { JLF;ANTUNES, JOSÉ L. F.;ANTUNES, J.L.F.;ANTUNES, J LF }\end{array}$ \\
\hline Lattes iD & (9) http://lattes.cnpq.br/4938720890035457 \\
\hline Orcid iD & ? (D) https://orcid.org/0000-0003-3972-9723 \\
\hline \multicolumn{2}{|l|}{ Endereço } \\
\hline \multirow[t]{2}{*}{ Enderego Profissional } & $\begin{array}{l}\text { Universidade de São Paulo, Faculdade de Saúde Pública, Departamento de Epidemiologia. } \\
\text { Av. Dr. Arnaldo, } 715 \\
\text { Pacaembu }\end{array}$ \\
\hline & $\begin{array}{l}\text { 01246-904 - Sao Paulo, SP - Brasil } \\
\text { Telefone: (11) 30617968 } \\
\text { URL da Homepage: htto: //www.fsp.usp.br }\end{array}$ \\
\hline
\end{tabular}

Formação acadêmica/titulação

\begin{tabular}{|c|c|}
\hline $1990-1994$ & $\begin{array}{l}\text { Doutorado em Sociologia (Conceito CAPES 6). } \\
\text { Universidade de São Paulo, USP, Brasil. } \\
\text { Título: Crime, sexo, morte: avatares da medicina no Brasil, Ano de obtenção: } 1995 . \\
\text { Orientador: (G) Irene de Arruda Ribeiro Cardoso. } \\
\text { Bolsista do(a): Conselho Nacional de Desenvolvimento Científico e Tecnológico, CNPq, } \\
\text { Brasil. } \\
\text { Palavras-chave: história e saúde; pensamento médico; medicina legal; saúde pública; moral. } \\
\text { Grande área: Ciências da Saúde } \\
\text { Grande Área: Ciências Humanas / Área: Sociologia / Subárea: Sociologia da Saúde. } \\
\text { Grande Área: Ciências da Saúde / Área: Medicina / Subárea: Medicina Legal e Deontologia. } \\
\text { Setores de atividade: Saúde Humana. }\end{array}$ \\
\hline $1985-1989$ & $\begin{array}{l}\text { Mestrado em Sociologia (Conceito CAPES 6). } \\
\text { Universidade de São Paulo, USP, Brasil. } \\
\text { Título: Hospital: Instituição e História Social,Ano de Obtenção: } 1989 . \\
\text { Orientador: Irene de Arruda Ribeiro Cardoso. } \\
\text { Bolsista do(a): Conselho Nacional de Desenvolvimento Científico e Tecnológico, CNPq, } \\
\text { Brasil. } \\
\text { Palavras-chave: hospital; análise institucional; instituições de saúde; história e saúde. } \\
\text { Grande área: Ciências Humanas } \\
\text { Grande Área: Ciências da Saúde / Área: Saúde Coletiva / Subárea: Saúde Pública. }\end{array}$ \\
\hline
\end{tabular}

